\title{
Empirical Validation of the Conceptual Design of the LLNL 60-kg Contained-Firing Facility
}

\author{
John W. Pastrnak \\ Charles F. Baker \\ Larry F. Simmons
}

February 24, 1995

This is an informal report intended primarily for internal or limited external distribution. The opinions and conclusions stated are those of the authors and may or may not be those of the Laboratory.

Work performed under the auspices of the U.S. Department of Energy by the Lawrence Livermore National Laboratory under Contract W-7405-Eng-48. 


\section{DISCLAIMER.}

This document was prepared as an account of work sponsored by an agency of the United States Government. Neither the United States Government nor the University of California nor any of their employees, makes any warranty, express or implied, or assumes any legal liability or responsibility for the accuracy, completeness, or usefulness of any information, apparatus, product, or process disclosed, or represents that its use would not infringe privately owned rights. Reference herein to any specific commercial product, process, or service by trade name, trademark, manufacturer, or otherwise, does not necessarily constitute or imply its endorsement, recommendation, or favoring by the United States Government or the University of California. The views and opinions of authors expressed herein do not necessarily state or reflect those of the United States Government or the University of California, and shall not be used for advertising or product endorsement purposes.

This report has been reproduced directly from the best available copy.

Available to DOE and DOE contractors from the Office of Scientific and Technical Information P.O. Box 62, Oak Ridge, TN 37831

Prices available from (615) 576-83401, FTS 626-8401

Available to the public from the National Technical Information Service

U.S. Department of Commerce 5285 Port Royal Fid., Springfield, VA 22161 


\section{DISCLAIMER}

Portions of this document may be illegible in electronic image products. Images are produced from the best available original document. 


\section{Contents}

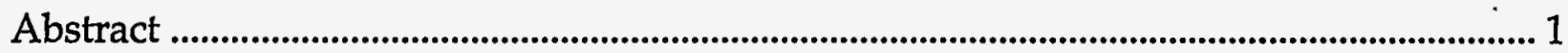

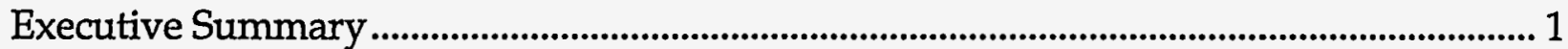

Rationale for Contained Firing ......................................................................................................... 2

CFF Description ....................................................................................................................... 2

Design Equivalency Criteria .................................................................................................... 4

Environmental Considerations ............................................................................................. 4

Blast-Effects Supplemental Testing ............................................................................................. 5

Shrapnel Mitigation ........................................................................................................... 5

Close-in Shock Loading ............................................................................................................. 6

Qualification and Acceptance Testing ................................................................................... 6

Total Structural Response Experiments-Firing Chamber Scale Model .............................. 6

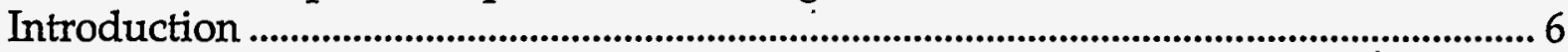

Design Considerations .............................................................................................................. 7

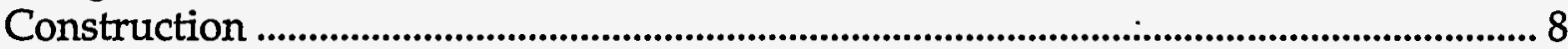

Experimental Setup .................................................................................................... 12

Instrumentation ................................................................................................................... 15

Empirical Results ........................................................................................................................ 18

Observations and Conclusions .......................................................................................... 20

Notes and References ........................................................................................................... 26

Appendix A - Tabular Strain Data ............................................................................................ 27

Table A1 Maximum tensile strains ..................................................................................28

Table A2 Maximum compressive strains.......................................................................29

Table A3 Maximum tensile stresses ................................................................................30

Table A4 Maximum compressive stresses ...........................................................................31

Table A5 Maximum tensile safety factors (SF) to yield ................................................32

Table A6 Maximum compressive safety factors (SF) to yield .....................................33

Appendix B - Structural Drawings...................................................................................34

Appendix C - Instrumentation Drawings ................................................................................. 40 


\title{
Empirical Validation of the Conceptual Design of the LLNL 60-kg Contained-Firing Facility
}

\author{
John W. Pastrnak \\ Charles F. Baker \\ Larry F. Simmons
}

\begin{abstract}
In anticipation of increasingly stringent environmental regulations, Lawrence Livermore National Laboratory (LLNL) is proposing to modify an existing facility to add a $60-\mathrm{kg}$ firing chamber and related support areas. This modification will provide blast-effects containment for most of its open-air, highexplosive, firing operations. Even though these operations are within current environmental limits, containment of the blast effects and hazardous debris will further drastically reduce emissions to the environment and minimize the hazardous waste generated.

The major design consideration of such a chamber is its overall structural dynamic response in terms of its long-term ability to contain all blast effects from repeated internal detonations of high explosives. Another concern is how much other portions of the facility outside the firing chamber must be hardened to ensure personnel protection in the event of an accidental detonation while the chamber door is open.

To assess these concerns, a 1/4-scale replica model of the planned contained firing chamber was engineered, constructed, and tested with scaled explosive charges ranging from 25 to $125 \%$ of the operational explosives limit of $60 \mathrm{~kg}$. From 16 detonations of high explosives, 880 resulting strains, blast pressures, and temperatures within the model were measured to provide information for the final design.
\end{abstract}

\section{Executive Summary}

Based on measurements obtained from scaled detonation experiments within a 1/4-scale replica model, factors of safety for dynamic yield of the firing chamber structure were calculated and compared to the design criterion of totally elastic response. The rectangular, reinforced-concrete chamber model exhibited a lightly damped vibrational response that placed the structure in alternating cycles of tension and compression. During compression, both the reinforcing steel and the concrete remained elastic. During tension, the reinforcing steel remained elastic, but the concrete elastic limit was exceeded in two areas, the center spans of the ceiling and the north wall, where elastic safety factors as low as 0.66 were obtained, thus indicating that the concrete would be expected to crack in those areas. Indeed, visual posttest inspection of those areas revealed tight cracks in the concrete.

Internal blast pressures averaged 2 to 3 times greater than expected. Quasistatic gas pressures peaked at 18 psig, roughly $86 \%$ of the 21 psig predicted by calculation.

External blast overpressures from an accidental detonation scenario ranging from 0.1 to $70 \mathrm{psig}$ were measured during the open-door tests at 22 locations outside the firing chamber model.

In general, these experiments have demonstrated that a rectangular, conventionally reinforced, concrete structure can be used as a firing chamber. More specifically, they have validated the conceptual design prepared by the architectural/engineering firm of Holmes and Narver. 


\section{Rationale for Contained Firing}

Since 1955, Lawrence Livermore National Laboratory (LLNL) has conducted open-air explosives detonations at its Site 300 remote test complex. The Laboratory uses its explosives test facilities to precisely measure critical variables of importance to nuclear weapon designs, to test conventional ordnance designs, and to evaluate possible accidents (such as fires) involving explosives. Although emissions to the environment from open-air testing at LLNL's facilities currently do not exceed current environmental standards, this may not always be the case.

In anticipation of stricter environmental regulations and because of the Secretary of Energy's mandate that environmental, safety, and health $(E S \& H)$ concerns be the first priority at all U.S. Department of Energy (DOE) facilities, LLNL is developing a comprehensive, state-ofthe-art, blast-effects containment (or containedfiring) facility (CFF) (see Fig. 1). This is needed to reduce emissions of hazardous materials and the amount of contaminated wastes generated by explosives testing while providing a continuing capability to test nuclear and other assemblies that contain high explosives. A permanent, stateof-the-art firing chamber is to be constructed around and integrated into an existing facility's open-air firing surface to completely contain blast effects and thereby enhance environmental protection, waste minimization, and safety for the 21 st century. 1

\section{CFF Description}

The CFF project consists of adding about $2463 \mathrm{~m}^{2}$ of structural additions to the existing open-air firing facility at Bunker 801, the site of LLNL's existing world-class $17-\mathrm{MeV}$ flash $\mathrm{x}$-ray (FXR) machine. Bunker 801 already contains a variety of high-speed optical and electronic diagnostic equipment, which, together with the FXR, provide unique diagnostic capability. The new additions consist of four components: a firing chamber, a support area, a diagnostic equipment area, and an office/conference module, as shown in Fig. 2.

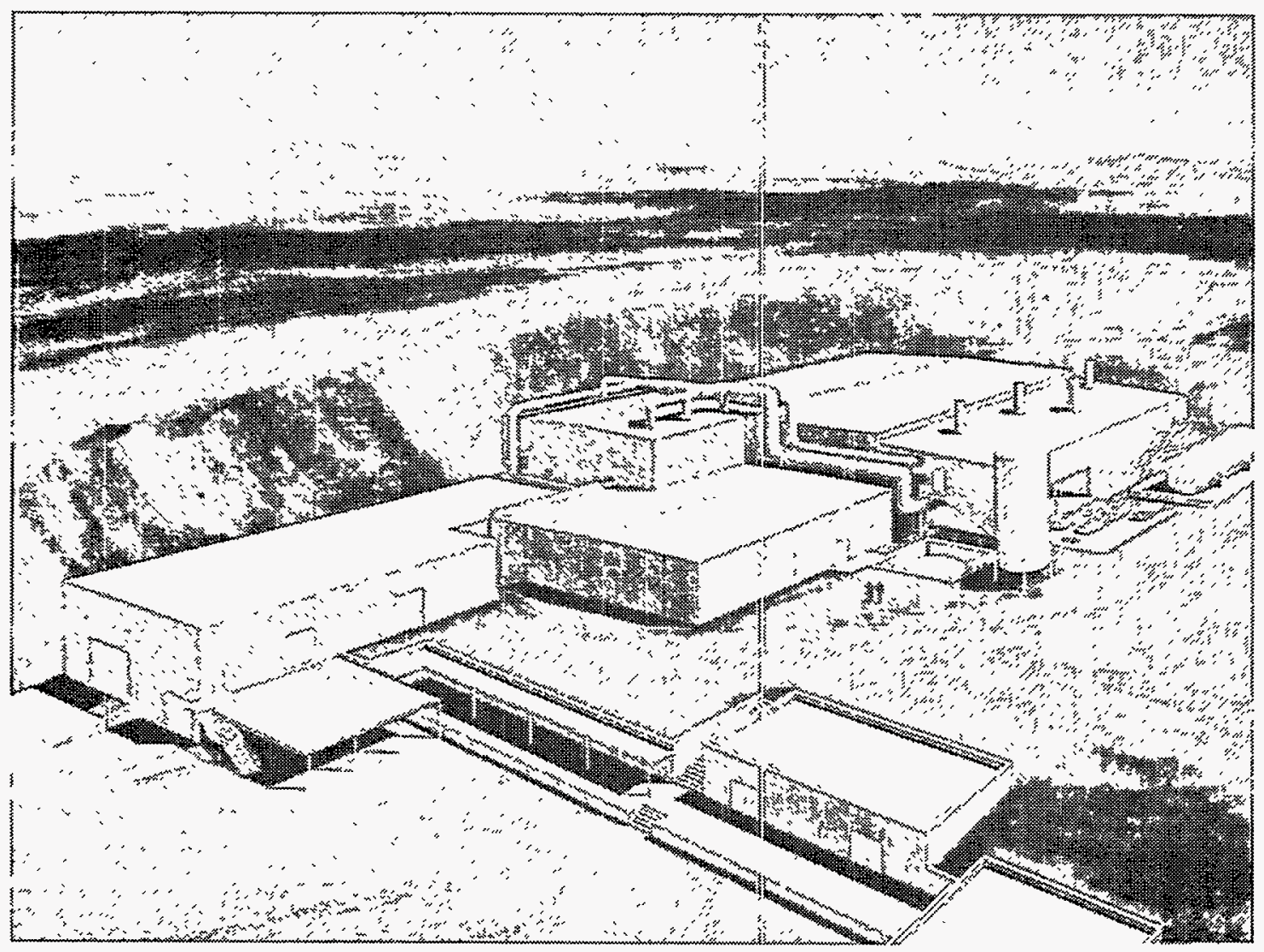

Figure 1. Artist's concept of the planned Contained Firing Facility. 


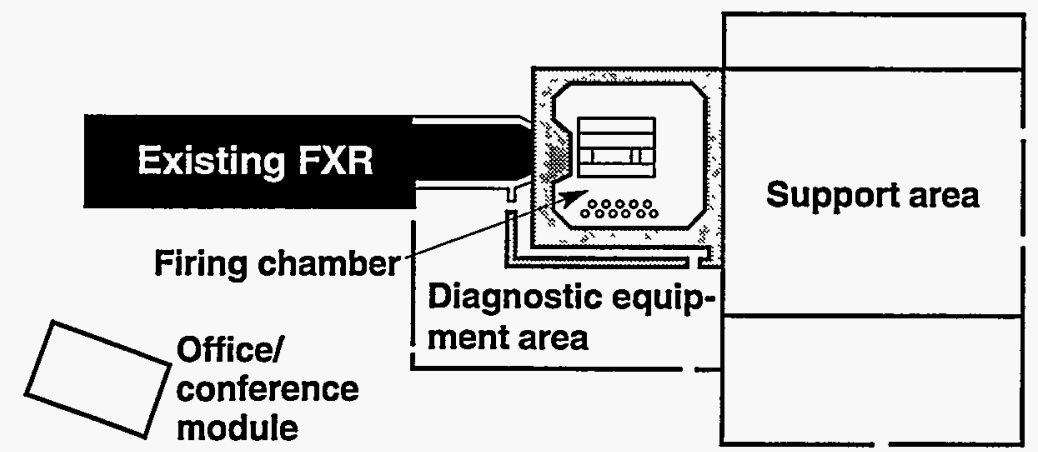

Figure 2. Plan view of the proposed Contained Firing Facility additions to Bunker 801.

The heart of the CFF is the firing chamber (see Fig. 3). Slightly larger than half a gymnasium, the firing chamber will contain the blast overpressure and fragmentation effects from detonations of cased explosive charges up to $60 \mathrm{~kg}$. The inside surfaces of the chamber will be protected from high-velocity shrapnel that results from detonating cased explosives. To permit repetitive firings, all main structural elements of the firing chamber are required to remain elastic when subjected to blast. Detonations will be conducted above a 150 -mm-thick steel firing surface (the shot anvil) embedded in the floor.

Explosive quantity zones, with capabilities for operational masses up to $60 \mathrm{~kg}$ of PBX-9404 (a plastic-bonded explosive containing $94 \% \mathrm{HMX})^{2}$ or an equivalent TNT mass of $78 \mathrm{~kg}$, are shown in Fig. 3 for detonations at the nominal distance of $1.22 \mathrm{~m}$ above the anvil surface. Separate, generalpurpose, removable shielding protects the

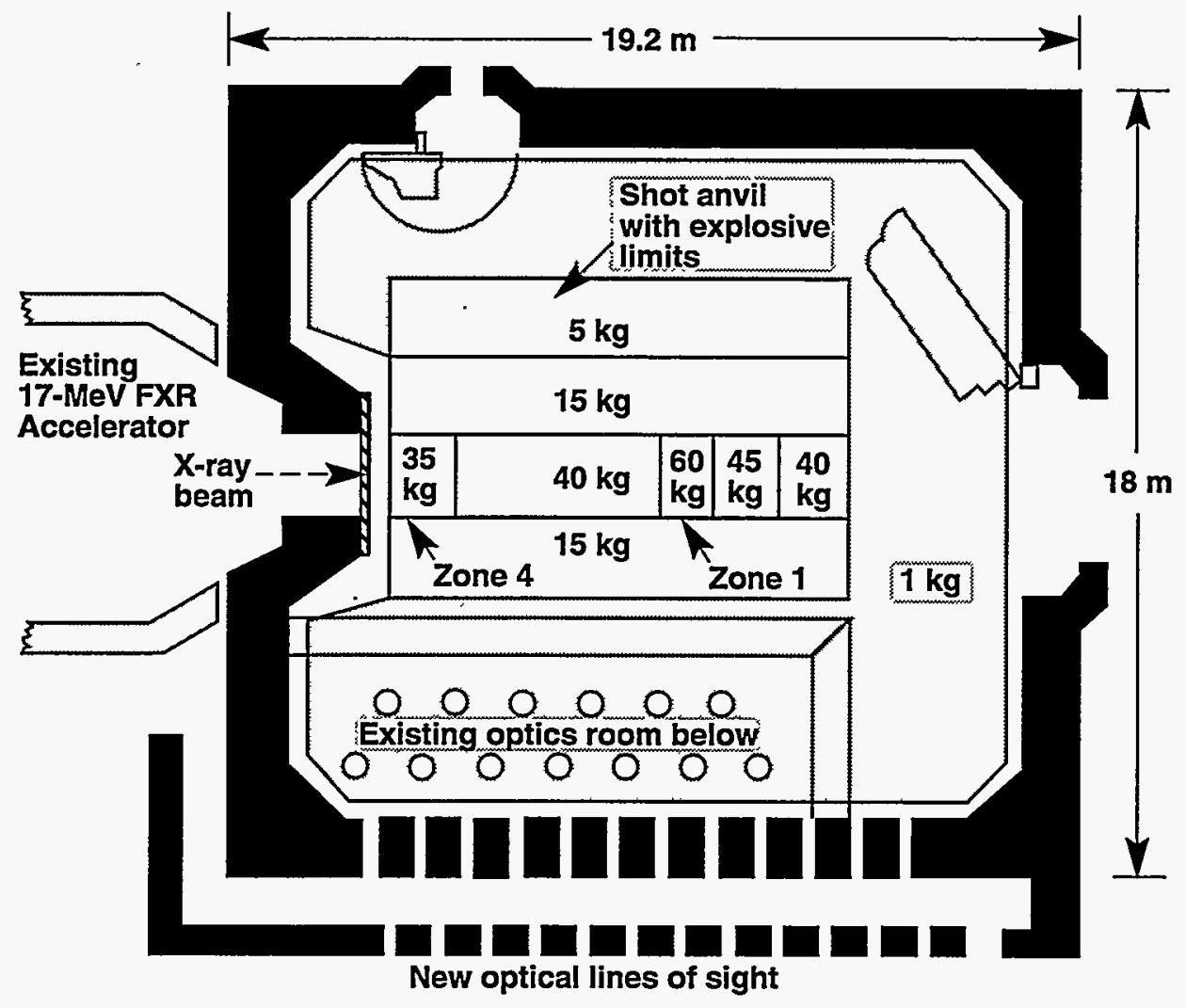

Figure 3. Plan view of the firing chamber, showing shot detonation zones, with corresponding high-explosive mass limits. 
interior surfaces of the firing chamber from highvelocity fragments. A key aspect of the CFF is that the rectangular concrete firing chamber will be made with low-cost, conventional reinforcement, as opposed to the labor-intensive, laced reinforcement commonly found in many blastresistant structures. From a materials standpoint, a spherical chamber shape would be more blast efficient, but a slightly heavier, rectangular shape is cheaper, provides easier and more desirable setup and working surfaces, and encompasses existing diagnostic systems. The thickness of the reinforced concrete walls, ceiling, and floor of the chamber are $1.22,1.37$, and $1.83 \mathrm{~m}$, respectively.

The locations of existing camera ports and the end of the FXR accelerator (see Fig. 3), all of which must be in the chamber, led to the selection of a chamber area of about $344 \mathrm{~m}^{2}$, with an interior height of $9.5 \mathrm{~m}$.

The support area (about $1543 \mathrm{~m}^{2}$ ) provides a staging place for preparing the nonexplosive components of an experiment, equipment and materials storage, personnel locker rooms, rest rooms, and decontamination showers. It also houses the filters, scrubbers, and a temporary waste-accumulation area for the waste products from testing.

The diagnostic equipment area (about $576 \mathrm{~m}^{2}$ ) will accommodate multiple-beam optical equipment to measure, through 12 horizontal optical lines of sight (LOSs) into the firing chamber, velocity-time histories from as many as 40 points on an explosively driven metal surface. These are in addition to 11 vertical optical LOSs from the existing camera room situated below the chamber floor. The diagnostics area is similar in construction to the support area and will also protect personnel who may occupy it during explosives tests.

\section{Design Equivalency Criteria}

The criterion for the design of the CFF is that it be able to elastically survive the blast effects from detonating up to $60 \mathrm{~kg}$ of an energetic explosive such as PBX-9404. Designing the chamber to survive this environment requires an equivalency conversion in the structural design process from energetic material to the de facto standard (TNT). The equivalent TNT mass is based on a single-worst-case equivalency factor that encompasses all maximum effects from blast and quasistatic gas pressure (currently used at
Site 300$)$. This factor $(\beta)$ is defined as the largest ratio of the heat of detonation for energetic materials to that of TNT:

$\beta=\max \left(\frac{\Delta H_{\text {energetic material }}}{\Delta H_{\mathrm{TNT}}}\right) \equiv 1.3$.

Due to variations in high-explosive charge initiation and the inaccuracies associated with construction materials, a safety factor of 1.2 is additionally specified ${ }^{3}$ in the design equivalency process. The amount of TNT equivalent for structural design purposes is thus given by

Mass of TNT design equivalent $=$

$\beta \cdot 1.2 \cdot[$ desired $\mathrm{HE}$ operational mass] .

For the $\mathrm{CFF}$, this amounts to

Mass of TNT design equivalent $=$ $1.3 \cdot 1.2 \cdot 60 \mathrm{~kg}=93.6 \mathrm{~kg}$,

which is the basis of all the design calculations by the architect/engineer $(\mathrm{A} / \mathrm{E})$.

\section{Environmental Considerations}

"Contained firing" implies complete containment of all blast effects associated with the detonation of cased high-explosive materials. This includes discharges to the environment in the form of noxious gases, particulate matter (aerosolized and chunky), and impulsive noise produced from the detonation. Although it is highly desirable to have a "zero discharge" criterion as a goal of the CFF project, it is recognized that this is nearly impossible to achieve and is excessively expensive to implement. Instead, the CFF project is based on a "near-zero discharge" policy, whereby small discharges that are within all environmental regulations may occur from time to time over the anticipated life of the facility. The distinction between the two is important socially and politically, in that small, environmentally acceptable, accidental discharges may result in closure of the facility if they are not anticipated and publicly acknowledged early in the design process.

The firing chamber will be a sealed structure that will contain not only very high-amplitude, short-duration impulsive shock pressures but 
also the much lower amplitude and longer duration quasistatic gas pressures that are typical of explosives detonated in closed firing chambers. Anchored to the inside of the concrete chamber surfaces is a thin, continuous, $12.7-\mathrm{mm}$ thick, mild-steel pressure liner, which will seal and prevent the detonation gases from passing through the concrete walls, ceiling, and floor, all of which may develop structurally acceptable hairline cracks as the facility ages. All doors, optical LOSs, and other intrusions into the firing chamber (such as the FXR bullnose) will have seals that allow the firing chamber to function as a pressure vessel to contain the blast and quasistatic pressure. After the gases cool, blast dampers will open, and ventilation fans will purge the chamber with fresh air. The exhaust gases will be processed through HEPA (highefficiency particulate air) filters and scrubbers before being released to the environment. Slight negative atmospheric pressures will be maintained afterward in the firing chamber and the support area to reduce the escape of unprocessed airborne hazardous particulates and gases to the environment.

Solid wastes and shot-related debris will be greatly diminished and can be collected and disposed of as low-level radiated waste or as mixed waste. In conjunction with management of these solid wastes, a reactive-waste certification program is being developed at LLNL. An internal, closed, water wash-down system is planned that will recirculate water spray within the chamber and filter out dust and particulates in the form of sludge. The CFF project will aggressively minimize waste by reducing the total solid waste to about one-tenth of the amount generated today.

\section{Blast-Effects Supplemental}

\section{Testing}

After review of the CFF conceptual design report (CDR), 4 four critical blast-effects design issues were identified that, due to their variability, would benefit from further investigation. A four-part program, primarily based on blast effects testing, was formulated in each of the following four areas:

- Shrapnel mitigation

- Close-in shock loading
- Qualification and acceptance testing

- Total structural response.

The focus of this report is the total structural response obtained by testing a 1/4-scale model of the firing chamber. The rationale for each of the other three testing programs is described briefly in the following sections.

\section{Shrrapnel Mitigation}

High-velocity fragments from cased explosives could do significant damage to the pressure liner in the firing chamber and thereby compromise the containment and sealing of hazardous gases and particulates. Worst-case, shrapnelproducing experiments at Site 300 were monitored and documented ${ }^{5}$ to evaluate various general-purpose shrapnel-protection schemes. The resulting design, shown in Fig. 4 , is a replaceable, general-purpose, multilayer, protection scheme to be installed on the inside concrete surfaces of the firing chamber. From this testing program, three important design modifications to the conceptual design could be realized:

- Additional local shielding would be required on an as-needed basis near those experiments that produce material with a directional nature (e.g., shaped charges). Addition of localized shielding would permit the overall general-purpose shielding to be thinner, resulting in a cost saving.

- General-purpose shielding made from mild steel instead of armor plate would be used because mild steel is roughly half the cost and provides about $85 \%$ of the penetration resistance of armor plate.

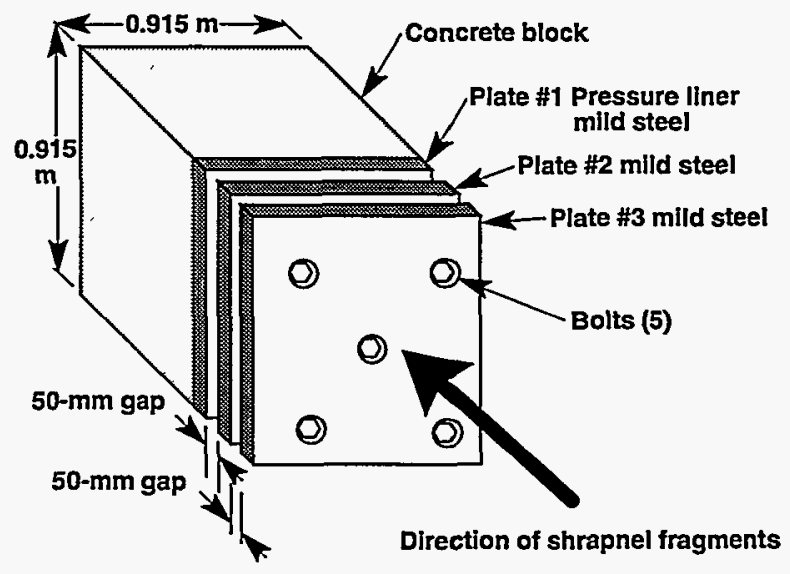

Figure 4. Shrapnel-mitigation testing apparatus. 
- Multilayer technology would be used, whereby thinner shrapnel-mitigation plates are separated by air spaces, thereby permitting the total thickness of shielding to be reduced and facilitating replacement and repair.

\section{Close-in Shock Loading}

The highest unit shock (blast) loading that the CFF must withstand will occur on the floor just below the 60-kg explosive charge location. Currently, due to diagnostic requirements of the FXR and the desired operational optical LOSs, this distance is $1.22 \mathrm{~m}$. This results in an extremely close-in $\left(Z=0.66 \mathrm{ft} / \mathrm{lb}^{1 / 3}\right)$ blast loading on the reinforced concrete floor of the chamber. Historically, floor damage from close-in loading has been a common problem for many blast chambers within the DOE/DoD (Department of Defense). Given this, the close-in blast loading on the chamber floor is considered to be one of the critical design issues for the proposed CFF. To investigate this concern, a series of 19 close-in blast loading experiments was conducted on a 1/4-scale section of the proposed floor design (see Fig. 5). The following conclusions were reached as a result of this testing. ${ }^{6}$

- Tensile strains in the concrete were 10 times the allowable dynamic tensile yield and would be likely to cause severe concrete cracking and pulverizing in the long term.

- A low-cost blast attenuation system was developed and tested that reduced the measured strains in the concrete to acceptable elastic levels to prevent severe pulverizing of the concrete.

- Measured strains in the reinforcement, the bolts, and the anvil were all within elastic limits for steel.

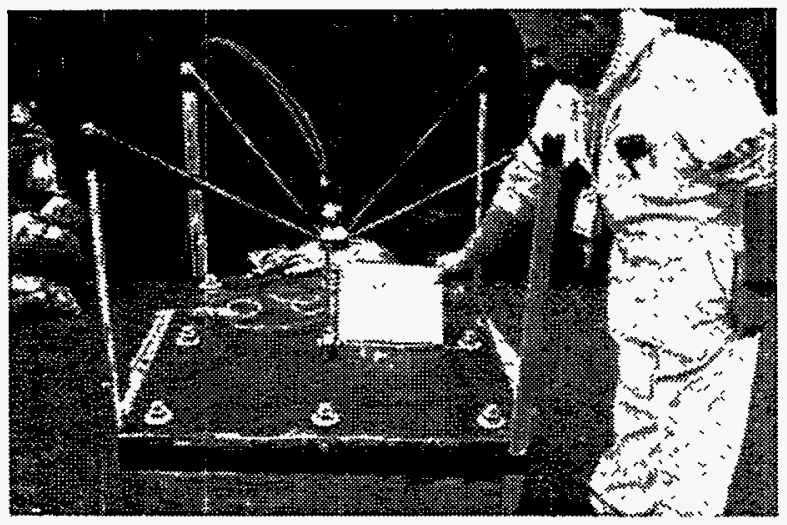

Figure 5. 1/4-scale floor section prior to testing at the $25 \%$ explosive weight level.

\section{Qualification and Acceptance Testing}

After the CFF is constructed but before it is used for normal experiments, a series of qualification/acceptance tests will be performed in the firing chamber to test it and the support systems. Explosives tests that produce up to $125 \%$ of the chamber pressure capacity are required by LLNL policy ${ }^{7}$ to further ensure that the facility has been safety constructed and that it meets or exceeds the original design criterion of totally elastic response. As with the 1/4-scale model of the firing chamber, the actual firing chamber will be instrumented with permanent gauging to assess the effects of the required qualification tests. The permanent strain gauges and pressure transducers can then be monitored at any time during detonations over the anticipated life of the firing chamber to ensure safe and reliable operation.

The remainder of this report describes 16 blast tests conducted in a quarter-scale model of the preliminary or conceptual chamber design.

\section{Total. Structural Response Experiments-Firing Chamber Scale Model}

\section{Introduction}

It is customary and good engineering practice to build and test scale models of highvalue, blast-resistant structures before the actual full-size structures are constructed. Testing of an instrumented scale model is particularly useful in verifying the preliminary design because it reveals potential construction defects and provides the best estimate of the actual blast loading environment for use in the final design. Recent experience from qualification testing of the contained firing vessels in the HighExplosives Applications Facility (HEAF) ${ }^{8}$ at the LLNL main site indicates that, in some regions, the highest measured strains occur after the shock loading has passed and are due primarily to the vibrational modes of the structure that are excited by the impulsive nature of the detonation.

To evaluate the CDR chamber design, a 1/4-scale replica model of the firing chamber was engineered, constructed, and instrumented with strain gauges, pressure transducers, and temperature gauges (see Fig. 6). 
Closed- and open-door tests were conducted by detonating high-explosive charges within the model. For the closed-door tests, the chamber was sealed to measure the normal maximum interior pressures, strains, and temperatures that would be expected on a routine, day-to-day basis (100\%) and from qualification/ acceptance over-tests at $125 \%$. As a result of confinement, realistic blast loadings with multiple reflections off of the ceiling and walls occurred, as did long-term quasistatic gas loadings.

Leaving the chamber door open during some experiments permitted outside blast pressures to be measured that could affect adjacent structures in the event that an accidental detonation occurs while a shot is being set up in the firing chamber. These blast measurements were used by the CFF A/E to assess and design adequate facility hardening (i.e., protection for those personnel who would not be directly involved in the pending explosive experiment, especially personnel in the locker room, the clean diagnostics area, and the small office/conference area).

\section{Design Considerations}

A scale factor of $1 / 4$ was chosen as a compromise between modeling scalability, cost, and internal accessibility. Since the rationale for testing was to verify that the overall or global response was within limits, nonessential design details and features specified in the CDR intentionally were left out of the scale model to keep the cost reasonable and the model simple.

In some cases, the deviations were improvements that made the model stronger or easier to build. It was further recognized that the CDR was, by nature, a preliminary design and was not intended to be a complete design. Therefore, some design details were based on established civil engineering practice and code regulations. The major additions and/or deviations from the $\mathrm{CDR}$ and the rationale for making them were as follows:

- Substituted single-level floor. The CDR called for a split-level floor that would be integrated with the existing camera room roof. The effect of the split level with intermediate support would have been a stronger and much more expensive scale model to construct. Instead, a single slab floor was constructed that, due to its longer span, would be weaker and thus would provide a more conservative verification of the conceptual design.

- Used equivalent replica scaled rebar. Exact replica (or geometric) scaling of the steel reinforcing bars (rebar) could not be achieved by using conventional common sizes. Instead, equivalent scaling was used by adjusting the inplane rebar spacing and size to try to maintain the $\mathrm{CDR}$ ratio of rebar to concrete. A comparison of the flexural reinforcement between the CDR and the 1/4-scale model is provided in Table 1.

- Simplified wall-to-floor joint. The CDR called for a notch or keyway in the concrete floor into which the walls would be tied and poured. Instead, upon advice from our civil engineers, this keyway joint was eliminated in favor of a simple, flush, butting connection between the floor and walls. As a result, the moment resistance of this joint would not be compromised and, for the purposes of our testing, the sealing capability would not be affected either. This again simplified the model design and reduced construction costs.

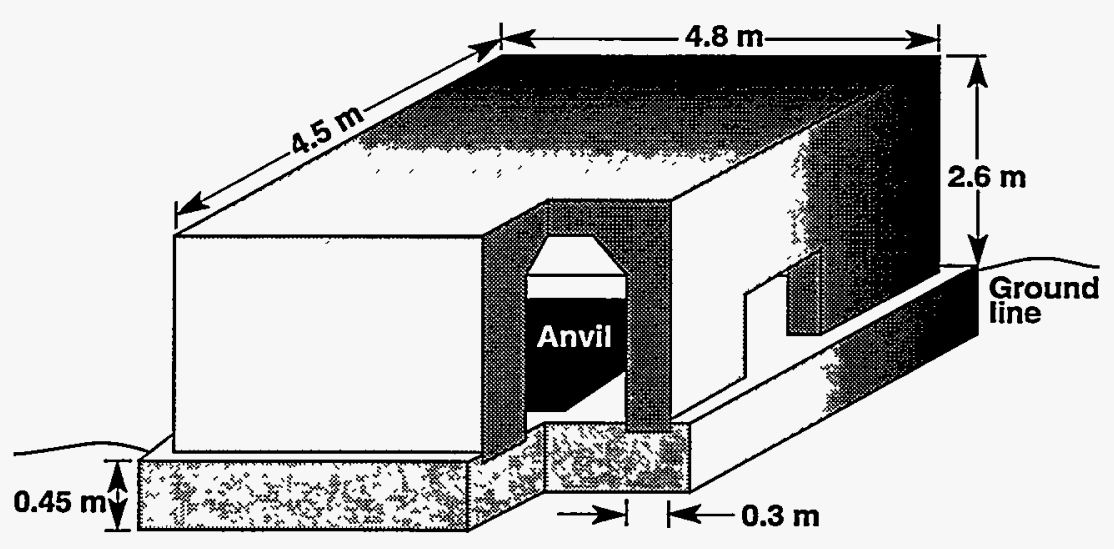

Figure 6. Quarter-scale model of the firing chamber. 
Table 1. Flexural reinforcement comparison between CDR and 1/4-scale chamber model.

\begin{tabular}{|c|c|c|c|c|c|c|c|c|c|c|c|c|c|}
\hline \multirow[b]{2}{*}{$\begin{array}{l}\text { Reinforce- } \\
\text { ment area }\end{array}$} & \multicolumn{6}{|c|}{ CDR } & \multicolumn{6}{|c|}{ 1/4-scale model } & \multirow[b]{2}{*}{$\begin{array}{c}\% \\
\text { difference } \\
\text { from } C D R^{a}\end{array}$} \\
\hline & $\begin{array}{l}\text { Bar } \\
\text { size }\end{array}$ & $\begin{array}{l}\text { No. } \\
\text { bars }\end{array}$ & $\begin{array}{c}\text { Shear } \\
\text { area per } \\
\left.\text { bar (in. }{ }^{2}\right)\end{array}$ & $\begin{array}{c}\text { Spacing } \\
\text { (in.) }\end{array}$ & $\begin{array}{c}\text { Concrete } \\
\text { thickness } \\
\text { (in.) }\end{array}$ & $\begin{array}{l}\text { Reinforce- } \\
\text { ment ratio }\end{array}$ & $\begin{array}{l}\text { Bar } \\
\text { size }\end{array}$ & $\begin{array}{l}\text { No. } \\
\text { bars }\end{array}$ & $\begin{array}{c}\text { Shear } \\
\text { area per } \\
\left.\text { bar (in. }{ }^{2}\right)\end{array}$ & $\begin{array}{l}\text { Spacing } \\
\text { (in.) }\end{array}$ & $\begin{array}{c}\text { Concrete } \\
\text { thickness } \\
\text { (in.) }\end{array}$ & $\begin{array}{l}\text { Reinforce- } \\
\text { ment ratio }\end{array}$ & \\
\hline Walls, vert., inner & 11 & 5 & 1.56 & 10 & 48 & 0.016 & 11 & 1 & 1.56 & 6 & 12 & 0.022 & +33 \\
\hline Walls, vert., outer & 11 & 3 & 1.56 & 10 & 48 & 0.010 & 7 & 1 & 0.6 & 6 & 12 & 0.001 & -15 \\
\hline Walls, horiz., inner & - 11 & 3 & 1.56 & 10 & 48 & 0.010 & 8 & 1 & 0.79 & 6 & 12 & 0.011 & +13 \\
\hline Walls, horiz., outer & 11 & 2 & 1.56 & 10 & 48 & 0.007 & 6 & 1 & 0.44 & 6 & 12 & 0.006 & -6 \\
\hline Roof, lower mat & 11 & 4 & 1.56 & 10 & 54 & 0.012 & 6 & 2 & 0.44 & 6 & 13.5 & 0.011 & -6 \\
\hline Roof, upper mat & 11 & 4 & 1.56 & 10 & 54 & 0.012 & 6 & 2 & 0.44 & 6 & 13.5 & 0.011 & -6 \\
\hline Floor, upper mat & 11 & 5 & 1.56 & 10 & 72 & 0.011 & 6 & 2 & 0.44 & 6 & 18 & 0.008 & -25 \\
\hline Floor, lower mat & 11 & 4 & 1.56 & 10 & 72 & 0.009 & 7 & 2 & 0.6 & 6 & 18 & 0.011 & +28 \\
\hline
\end{tabular}

a - means decrease from $\mathrm{CDR}$

+ means increase from CDR

- Eliminated diagnostic viewports. Details for optical port designs were not included in the CDR. Additionally, because the ports were so much smaller than the firing chamber, it was thought that the stress concentrations around the ports would be very limited and localized.

Simple pipe-and-flange ports were added to the model to facilitate flush-mounting the internal blast-pressure transducers on the inside surfaces of the chamber. These were typically ports with a 2-in. clear aperture but with steel blank flanges mounted instead of port glass. A large, 12-in., clear-aperture port was added for future experiments to help assess double-port glass-mounting schemes developed in HEAF. The 12-in. port was sealed off during testing with blank steel flanges.

Two 6-in. ports also were added in the roof at the northeast corner and in the south wall near the floor at the east wall corner. The 6-in. roof port was valved to allow the chamber to vent quasistatic pressure before reentry. The 6-in. wall port was fitted with a feedthrough to hold the detonator wires for firing the shots. The ports were located diagonally opposite each other for future experiments involving gases other than air to reduce the blast effects.

- Reduced coverage of general-purpose shrapnel-protection plates. Due to their low relative mass compared to the thick walls of the chamber, it was assumed that the shrapnel protection system and pressure liner would have a neglible effect on the overall dynamic structural response of the chamber. However, an area of concern is the rebounding of the pressure liner, which is anchored to the walls. The mass of the pressure liner and bolted-on shrapnel-protection plates produce significant inertial forces that have to be reacted through the anchors when the walls resonate due to the blast. To investigate this behavior and keep the construction costs reasonable, a 0.92 - by $0.92-\mathrm{m}$ section of the pressure liner and general-purpose shrapnel-protection system was added to the north wall of the model. The shrapnel-protection system was located at the center span of the wall, where it was expected to encounter the greatest rebound acceleration.

- Simplified blast/equipment access door. Since the CDR did not contain details of the large 3.6- by 4.3-m blast door and framework, a simple two-plate door system was used for personnel access and containment of the expected internal quasistatic pressure.

- Eliminated nonstructural features, such as the water wash-down and associated floordrainage systems, the ventilation system, utilities such as electricity and gas, and personnel-safety systems.

- Used unscaled concrete aggregate. No attempt was made to scale the concrete aggregate for the scale model because it is believed to have little or no impact on the dynamic response of the firing chamber. The aggregate size was reduced from that in the CDR ( $3 / 4$ in. max.) to $3 / 8$ in. for ease of installation, especially at the corners and other areas that were highly congested with rebar. The overall concrete compressive strength remained the same ( $6 \mathrm{ksi}$ nominal).

\section{Construction}

The 1/4-scale model of the firing chamber was constructed within the shot table area of Bunker 812 at Site 300. Laboratory engineers made construction drawings from the $C D R$ with the previously mentioned exceptions. Specifications for procurement/fabrication were then 
prepared with the assistance of LLNL's Plant Engineering Department, and fabrication was awarded to a contractor. Construction commenced on November 28, 1993, and was completed on January 22, 1994. The 1/4-scale model of the firing chamber met all of the contract specifications and was accepted on February 28, 1994. Appendix B contains the "as built" revisions of the construction drawings.

The reinforced-concrete firing chamber model was constructed in two separate pours that totaled $28 \mathrm{yd}^{3}$ of concrete. The chamber floor was poured first, and the roof and sides then were formed up and poured one month later (see Figs. 7, 8, and 9). Per the CDR, conventional unlaced steel rebar was used throughout the scale model. The chamber floor consisted of a rectangular, $16.75-\times 15.75-\times 1.5-\mathrm{ft}$ reinforcedconcrete slab set on a compacted base foundation. The base foundation started with $12 \mathrm{in}$. of compacted soil with a dry density of $104 \mathrm{lb} / \mathrm{ft}^{3}$ topped off with an additional 8 in. of class II aggregate base rock with a dry density of $142 \mathrm{lb} / \mathrm{ft}^{3}$ (see Ref. 9). A sample of the compacted base foundation was measured at $91.8 \%$ relative compaction. ${ }^{10}$
Concrete with a minimum compressive strength of 6000 psi was used per the CDR. For better placement, a plasticizer was added per the manufacturer's specifications. Cylinder test data ${ }^{11}$ showed the strength to be an average of 6050 psi at 28 days for the floor and 6200 psi for the rest of the chamber. Both pours were given a full, 10-day water cure.

The flexural steel reinforcing consisted of conventional grade 60 rebar tied in two parallel mats. The spacing between the floor, ceiling, and wall mats was nominally set to $15,8.5$, and 7.5 in., respectively. Table 1 lists the flexural reinforcing used to construct the model.

The steel shear reinforcing used was \#3, grade 60 rebar on 6-in. centers throughout the chamber.

To model the 6-in.-thick shot anvil, a single 7.5-ft $\times 7$-ft $\times 1.5$-in. mild-steel plate was inset and flush-mounted with the top surface of the floor. After both concrete pours had cured, highstrength expansive grout ${ }^{12}$ was pumped through special access holes in the anvil to eliminate voids and improve the contact between the bottom of the anvil and the concrete. The holes were then sealed with standard pipe plugs. After the grout

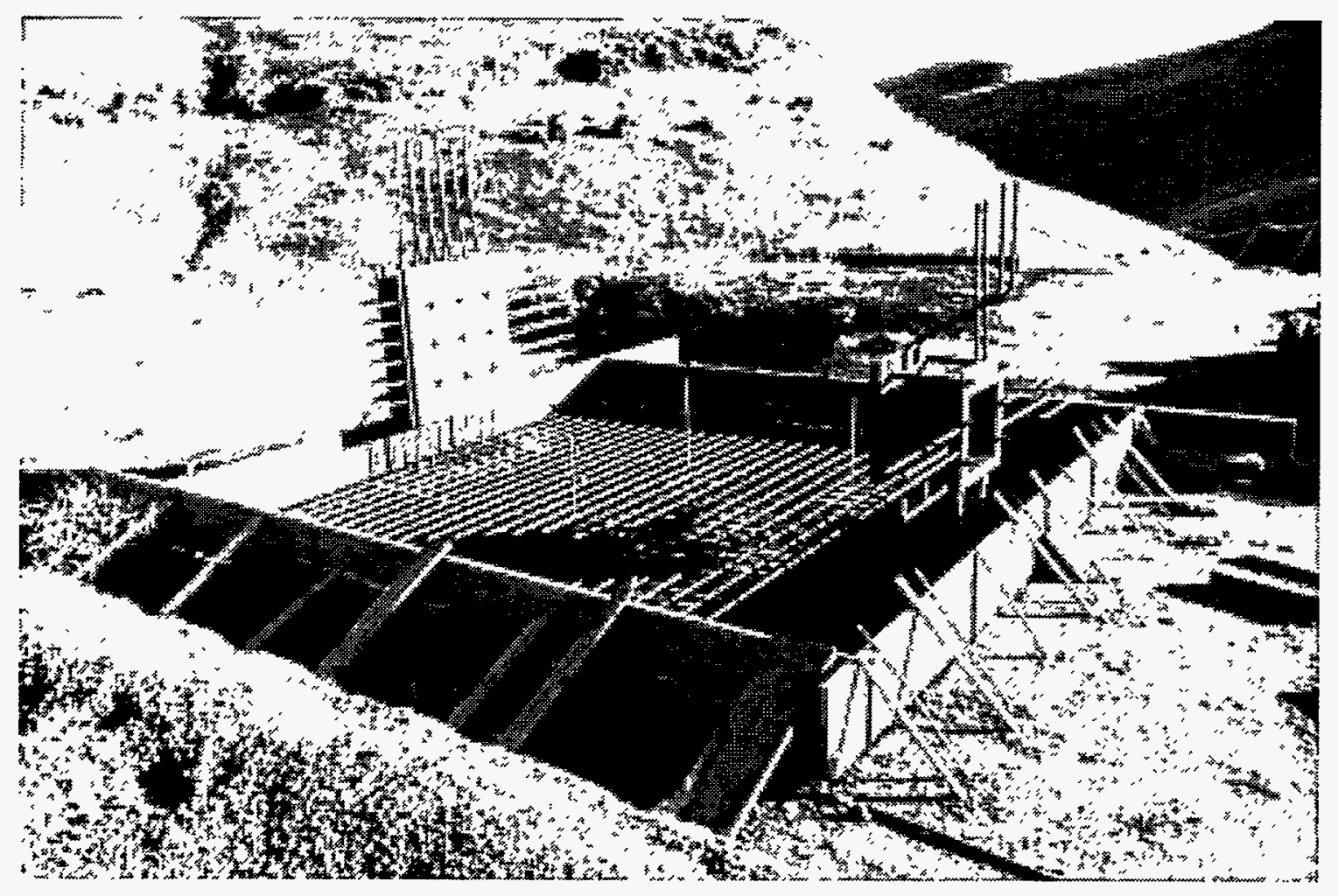

Figure 7. Early construction, showing embedments for the door (left) and bullnose (right). 


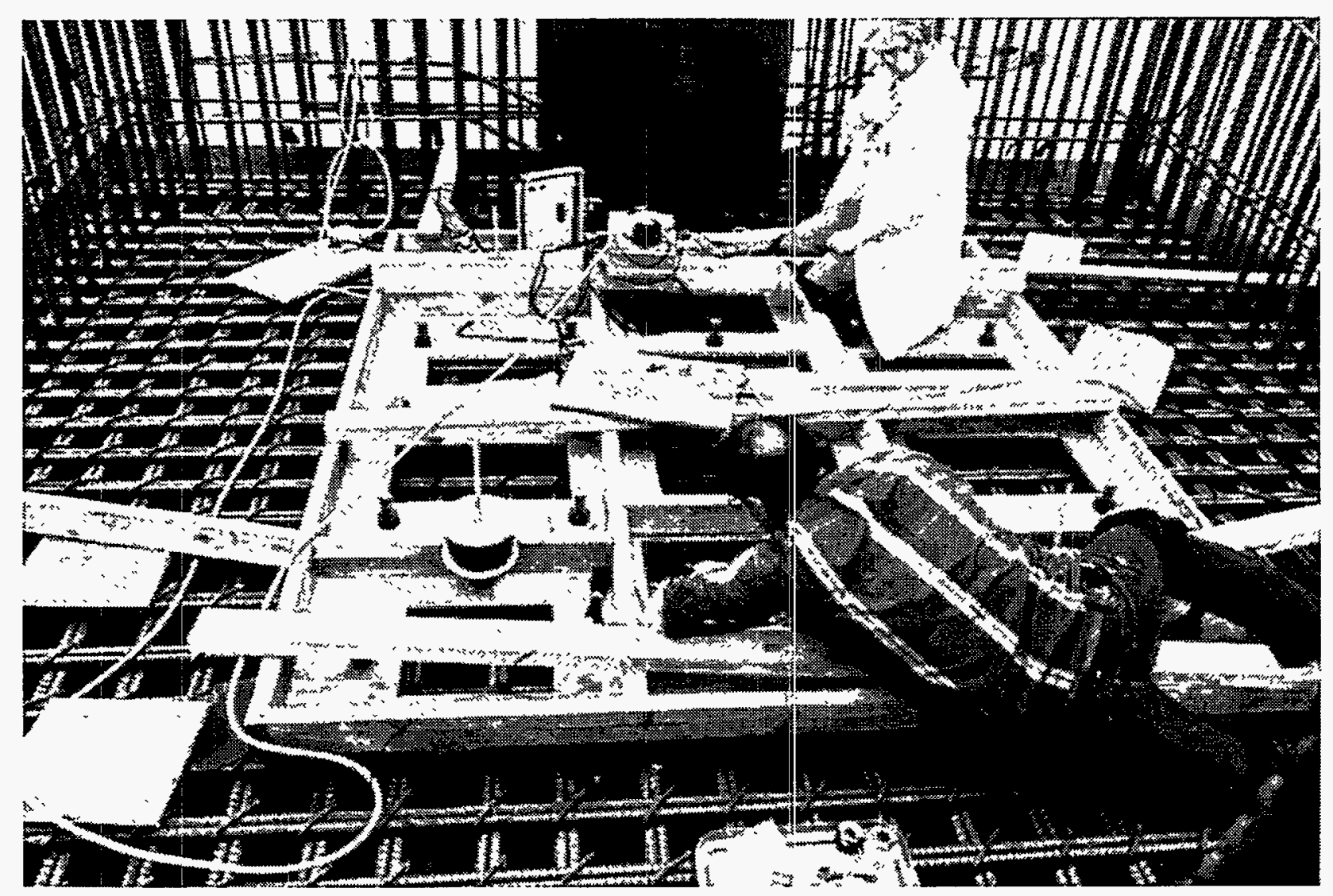

Figure 8. Technicians installing strain gauges in chamber prior to pouring concrete floor.

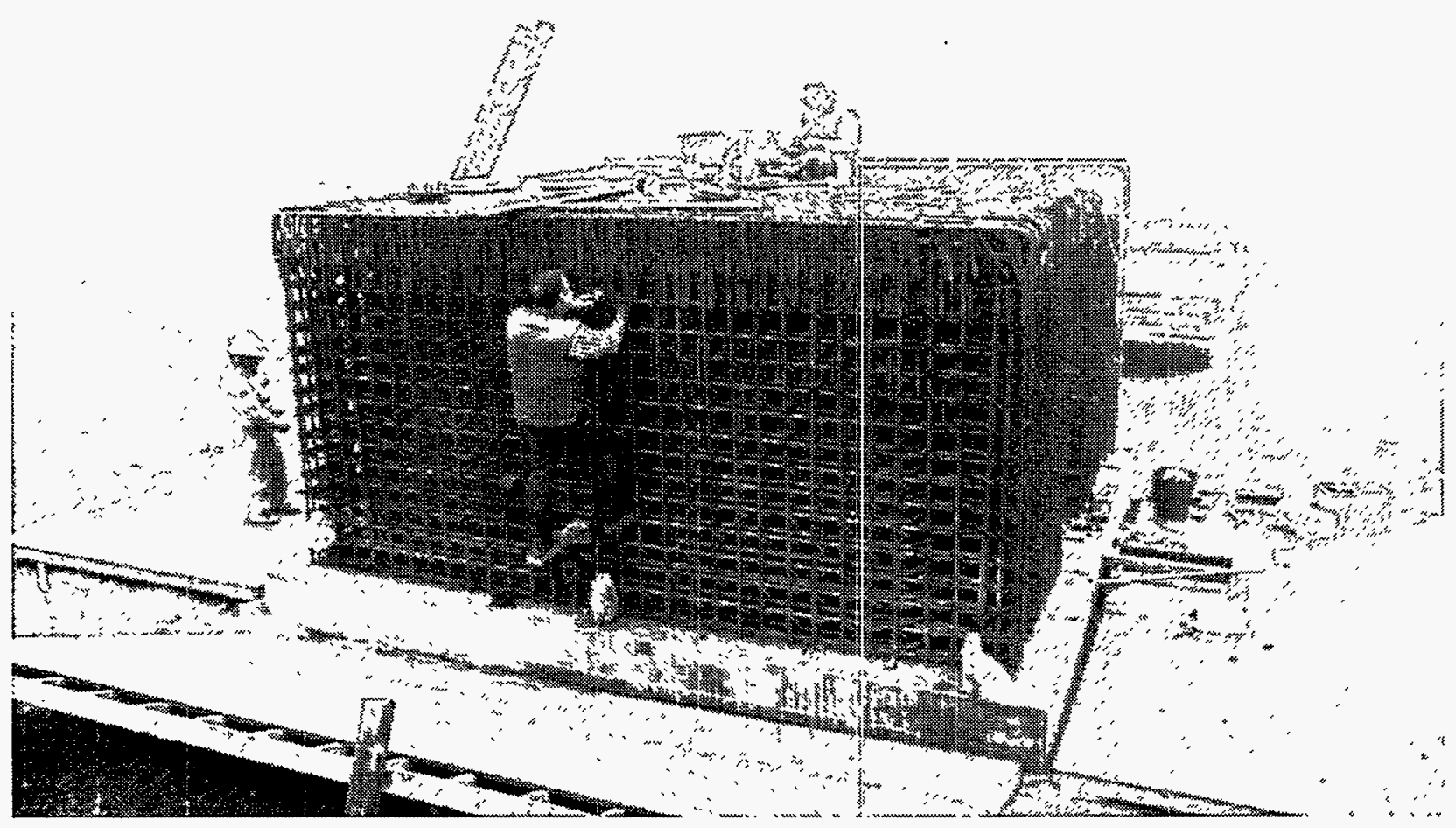

Figure 9. Final gauge installation prior to pouring walls and ceiling. 
cured, the shot anvil was secured to the floor with 251-in. $\times 9$-in.-long bolts torqued to $200 \mathrm{ft}-\mathrm{lb}$.

A 3-ft $\times 3-\mathrm{ft}$ square section of the pressure liner and general-purpose shrapnel-protection system was added to the inside surface on the north wall of the 1/4-scale model (see Fig. 10). The general-purpose shrapnel-protection system was a three-layer design - a thin pressure liner followed by two layers of shrapnel protection plates. The 1/8-in.-thick pressure liner had 1/8-in.-diameter by 4.25-in.-long J hooks welded to its backside on 6-in. centers. These hooks were fully embedded in the concrete during construction to provide good contact between the pressure liner and the concrete surface. On the front surface of the liner, 1-in.-diameter bosses were welded to support the shrapnel-protection plates. Two layers of 12- $\times 12-\times 0.25-$ in. mild-steel plates were then bolted to the liner using 1/4-in. studs and nuts. The plate edges were staggered between layers and were supported to give a 1/2-in. air gap between layers. Due to the staggering, $1 / 4$ and $1 / 2$ plate sections were used at the edges of the grid to provide the full dynamic mass from a rebound/pullout-resistance standpoint. For each full-size plate, five studs were used. The shrapnel plates were precoated with various high-temperature coatings to evaluate their ease of cleaning and durability from the effects of the explosive fireball.

A single 2.3-ft $\times 2.75-\mathrm{ft} \times 2$-in. steel plate hinged on a steel framework was used to seal the bullnose opening from the inside of the chamber. The frame, which was welded from 8-in. $\times 1 / 2$-in. angle, was cast or embedded into the concrete adjacent to the sealing plate. Figure 7 shows this embedment early in the construction process. A simple pipe hinge was constructed between the frame and the sealing plate so that the sealing plate would act as a bullnose door. Six 1-in. $\times 23-$ in.-long bolts were passed through the frame from the outside of the chamber into tapped holes in the back surface of the sealing plate to close off the bullnose opening. Figure 11 shows the 1/4-scale chamber model after the forms were removed.

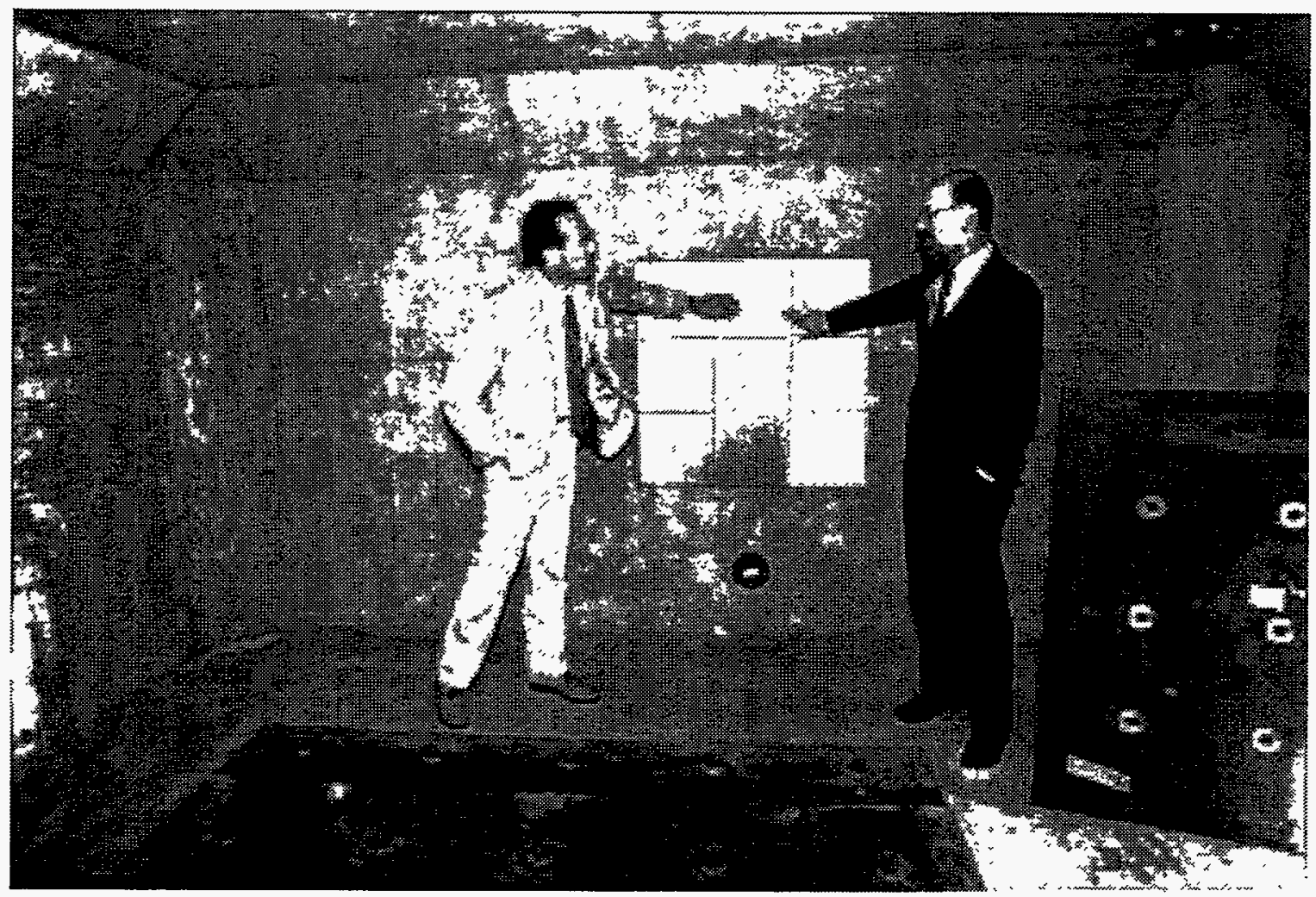

Figure 10. High-temperature coatings on shrapnel protection plates. 


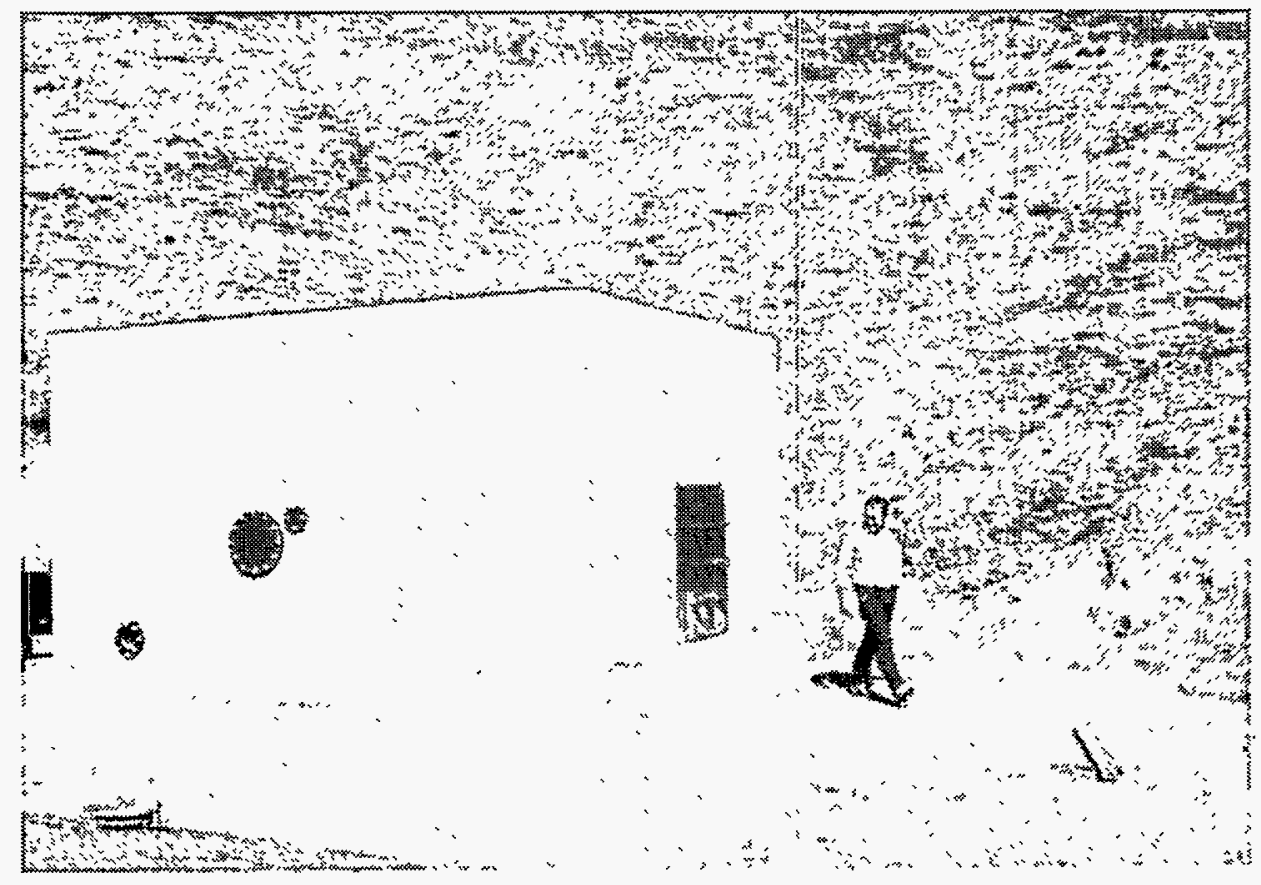

Figure 11. 1/4-scale chamber ready for testing.

\section{Experimental Setup}

Sixteen blast tests using $0.3 \mathrm{lb}(25 \%)$ to $2.58 \mathrm{lb}(125 \%)$ of $\mathrm{C} 4$ explosive were performed within the instrumented 1/4-scale chamber model. The charges were all spherical, double, center-detonated, bare high explosive. $\mathrm{C} 4$ explosive was used because it was readily available and closely matched the heat of detonation of the operational-limit explosive PBX9404. For each test, the charge was supported from ceiling hooks by lightweight strings such that the center of the charge was $12 \mathrm{in}$. above the top surface of the shot anvil. In the 1/4-scale model, the 12-in. elevation represented the FXR beam centerline, where most of the experiments would be conducted. Only two charge locations were used, but they were selected to provide the worst-case loading on the 1/4-scale structure. The first and largest charge location was in CDR Zone 1 near the center of the anvil (see Fig. 12). This represented the maximum operational charge limit of $60 \mathrm{~kg}$ of PBX-9404 and thus provided the worst-case global loading on the structure. The second location, with smaller charge amounts, was in CDR Zone 4 near the bullnose (see Fig. 13). This simulated close-in, highly localized loading on the bullnose. Table 2 shows the test matrix.
Closed-door tests were performed at four scaled levels $(25 \%, 50 \%, 100 \%$, and $125 \%)$ of the CFF operational explosive mass limit of $60 \mathrm{~kg}$ of PBX-94:04. The $125 \%$ shots were performed to simulate firing chamber overtesting, as required by Laboratory policy.

Since personnel would not be present in the adjacent parts of the CFF during the qualification testing, the worst-case scenario for an accidental detonation with the door open would be at the normal operational (100\%) explosive mass limit. Based on this reasoning, the open-door tests were performed at the $100 \%$ level (see Figs. 14 and 15).

Fior a replica scale model, the amount of explosive mass is scaled geometrically by the cube of the scale factor; i.e., $(1 / 4)^{3}=1 / 64$. Thus, $937.5 \mathrm{~g}$ of $\mathrm{C} 4$ high explosive detonated in the 1/4-scale model would be equivalent to $60 \mathrm{~kg}$ of $\mathrm{C} 4$ in the full-size chamber.

A.ccess to the interior of the chamber to set up the charges was gained through a $3-\times 3.5-\mathrm{ft}$ opening that represented the large CFF $12-\times 14-\mathrm{ft}$ equipment access door. Since the 1/4-scale model did not contain a built-in ventilation system or any personnel safety system monitors, the model was treated as a confined area. Therefore, portable oxygen sensors were used by shot personnel before entry to verify that sufficient oxygen was present. After each test was fired and the 


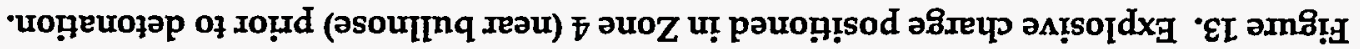

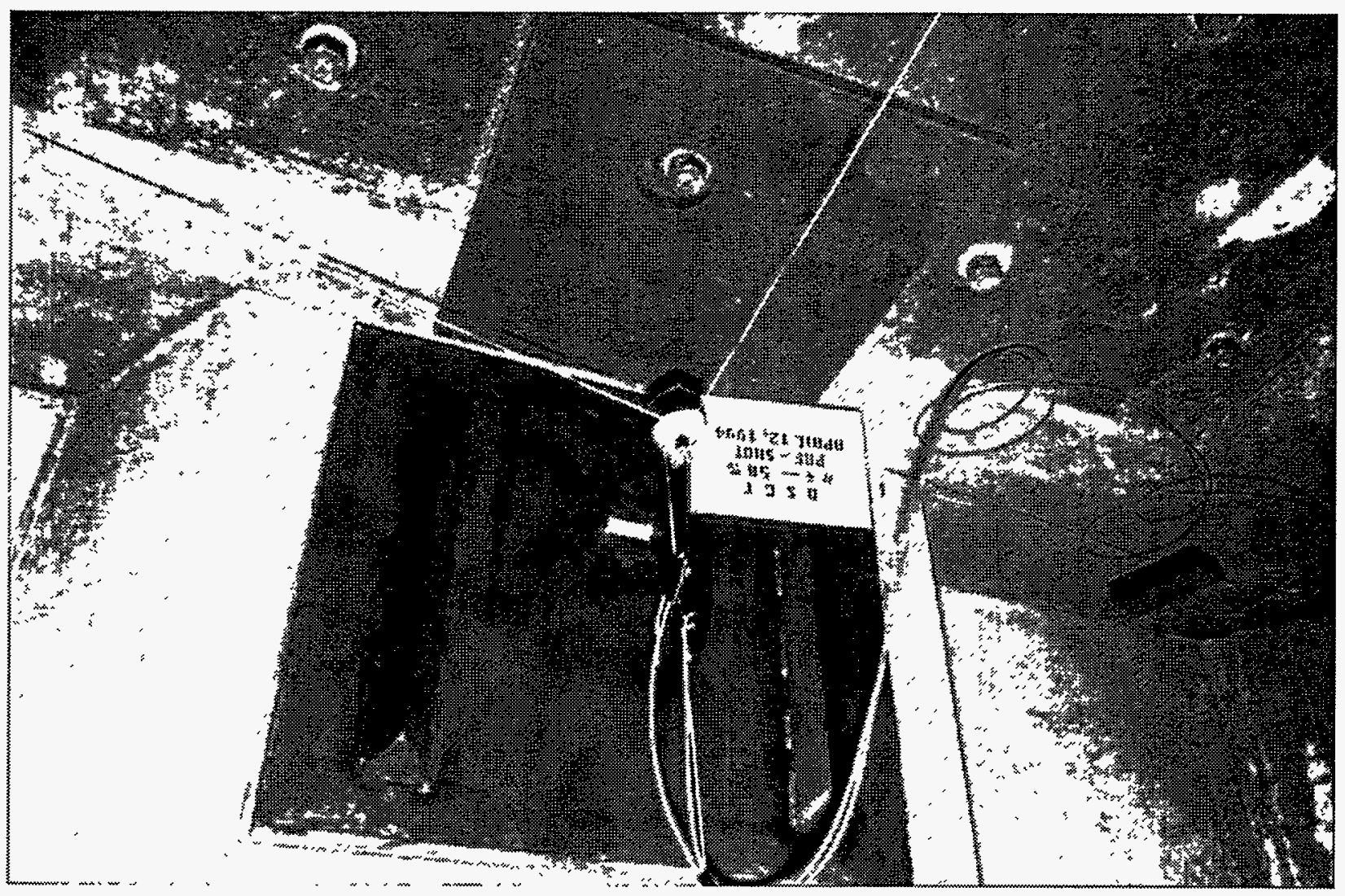

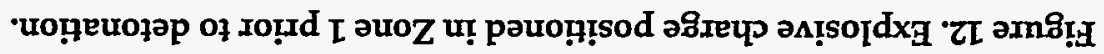

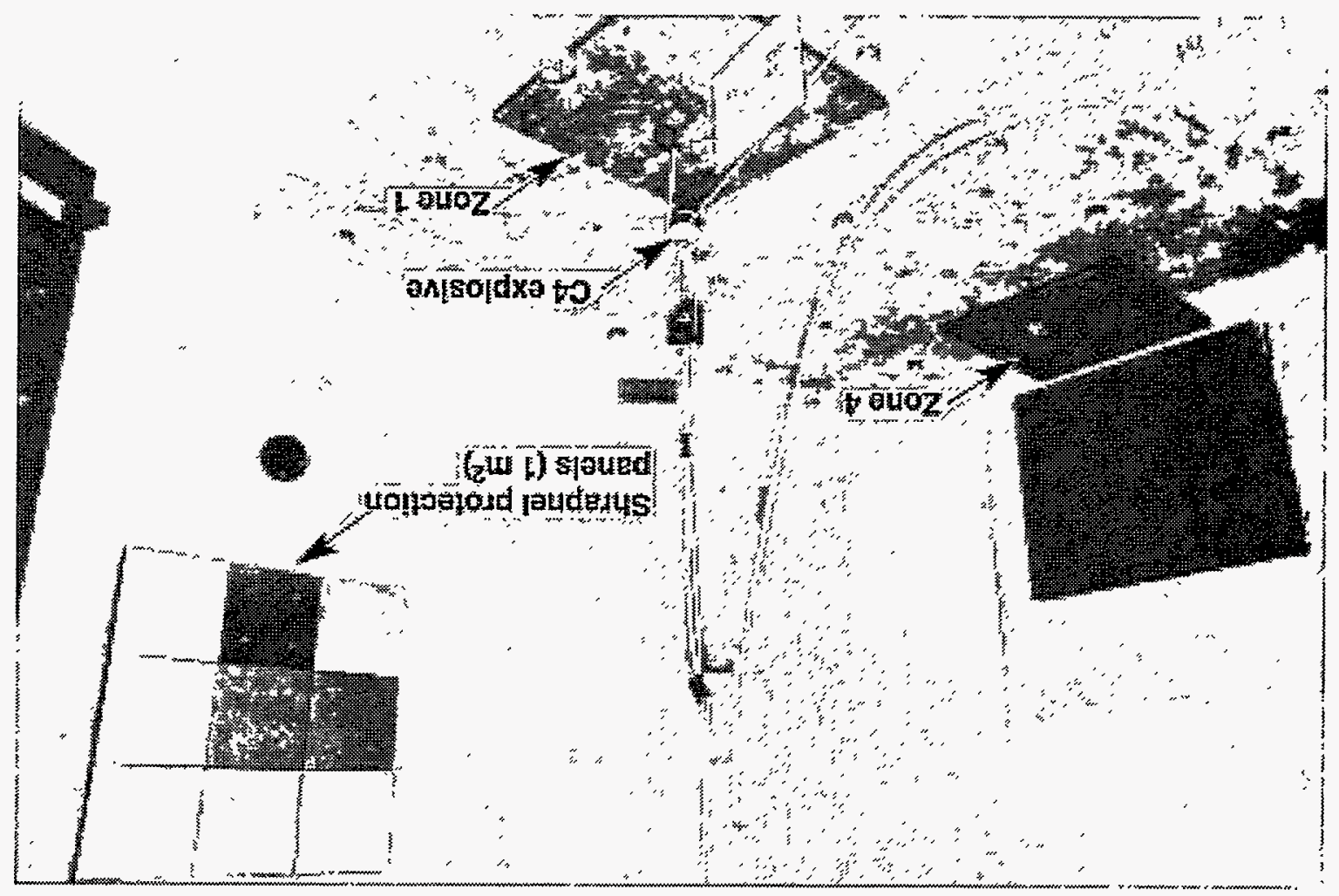


Table 2. 1/4-scale model testing matrix.13

\begin{tabular}{cccccccc}
\hline $\begin{array}{c}\text { Test \# } \\
\text { (sequence) }\end{array}$ & $\begin{array}{c}\text { Shot } \\
\text { (QSCT-\#) }\end{array}$ & Zone & $\begin{array}{c}\text { Door } \\
\text { position }\end{array}$ & $\begin{array}{c}\text { Energetic } \\
\text { material (lb) }\end{array}$ & $\begin{array}{c}\text { Max. equiv. } \\
\text { TNT (lb) }\end{array}$ & $\begin{array}{c}\text { \% operational } \\
\text { charge weight }\end{array}$ & $\begin{array}{c}Z_{\min } \\
\left(\mathrm{ft} / \mathrm{lb}^{1 / 3} \text { ) }\right.\end{array}$ \\
\hline 3 & 1 & 4 & Closed & 0.30 & 0.39 & 25 & 1.25 \\
1 & 2 & 1 & Closed & 0.52 & 0.67 & 25 & 1.14 \\
2 & 3 & 1 & Closed & 0.52 & 0.67 & 25 & 1.14 \\
\hline 6 & 4 & 4 & Closed & 0.60 & 0.78 & 50 & 1.00 \\
4 & 5 & 1 & Closed & 1.03 & 1.34 & 50 & 0.91 \\
5 & 6 & 1 & Closed & 1.03 & 1.34 & 50 & 0.91 \\
\hline 9 & 7 & 4 & Closed & 1.21 & 1.57 & 100 & 0.79 \\
7 & 8 & 1 & Closed & 2.07 & 2.58 & 100 & 0.72 \\
8 & 9 & 1 & Closed & 2.07 & 2.58 & 100 & 0.72 \\
\hline 14 & 10 & 4 & Closed & 1.51 & 1.96 & 125 & 0.73 \\
15 & 11 & 1 & Closed & 2.58 & 3.36 & 125 & 0.67 \\
16 & 12 & 1 & Closed & 2.58 & 3.36 & 125 & 0.67 \\
\hline 10 & 13 & 1 & Open & 2.07 & 2.58 & 100 & 0.72 \\
11 & 14 & 1 & Open & 2.07 & 2.58 & 100 & 0.72 \\
12 & 15 & 1 & Open & 2.07 & 2.58 & 100 & 0.72 \\
13 & 16 & 1 & Open & 2.07 & 2.58 & 100 & 0.72 \\
\hline
\end{tabular}

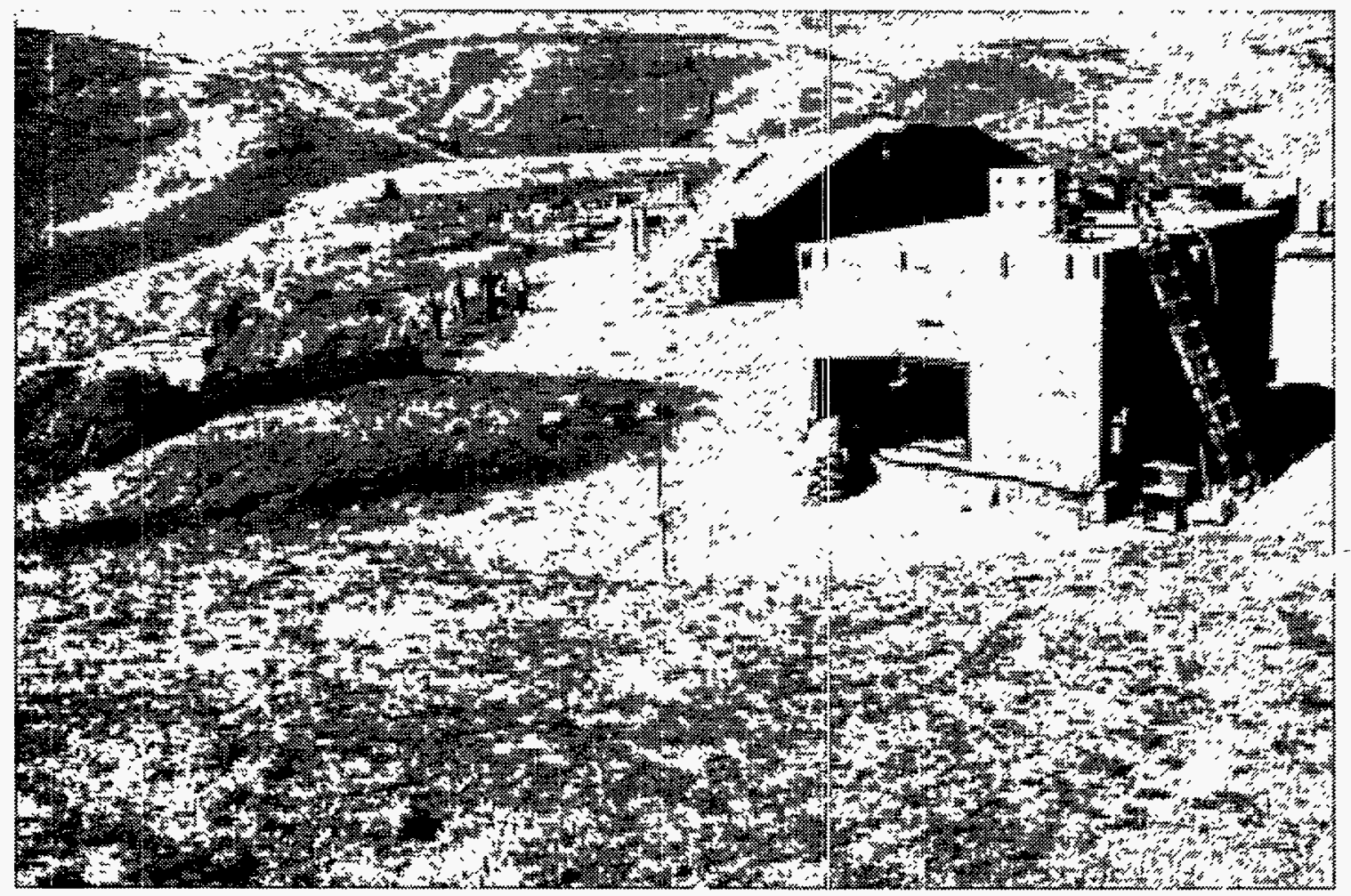

Figure 14. Open-door test setup with exterior blast transducers in foreground. 


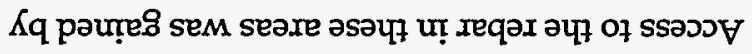

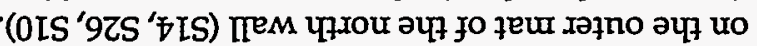
pue 'seq upuney II

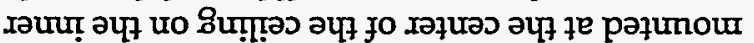

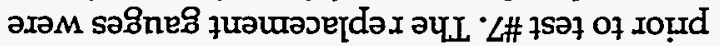

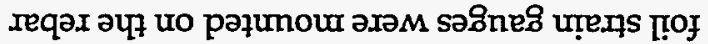

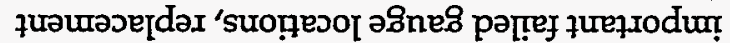

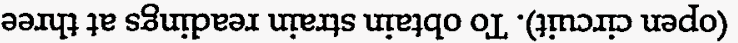

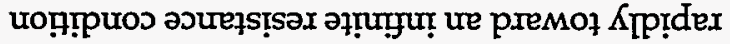

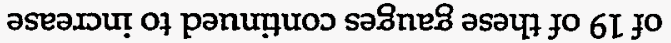

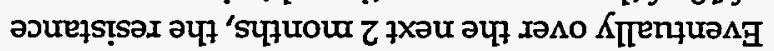

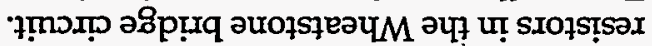

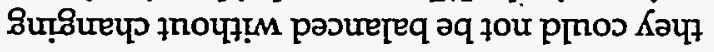

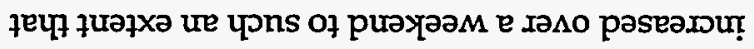

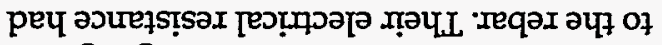

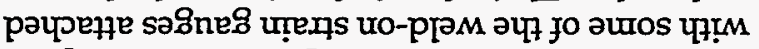

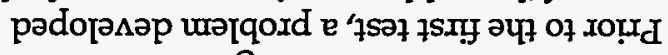

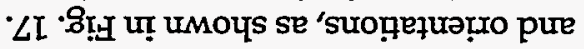

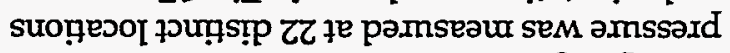

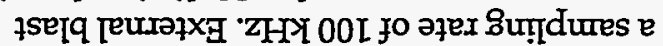

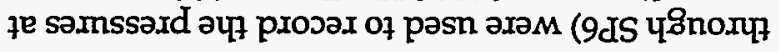
ZdS) ZLVLEL IวpoW pure (LdS) IIVLEI [əpour gOd

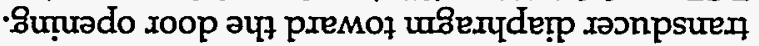

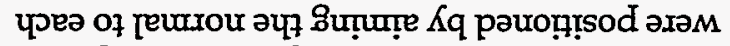
Кाпехәиว

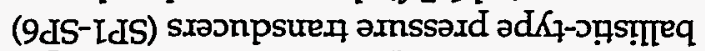
opadroł XỊs 'słsa子 xoop-uado mof aчt 'uog̣equaumxysur xoop-pasop aч7 jo

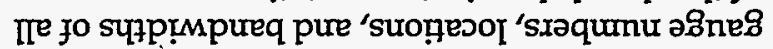

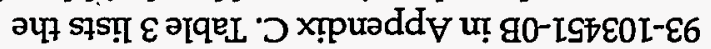

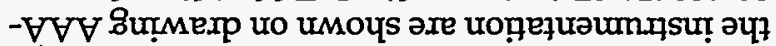

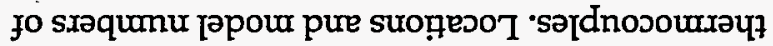

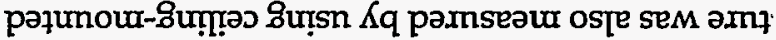

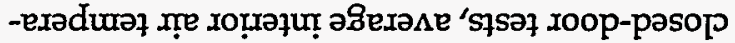
әч7 गо

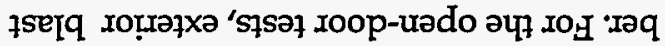

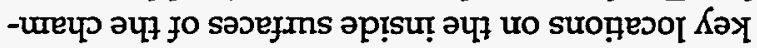

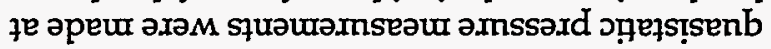

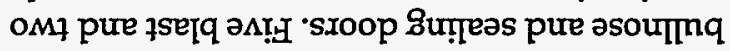

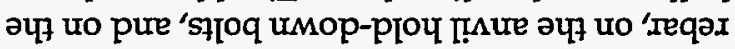

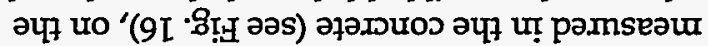

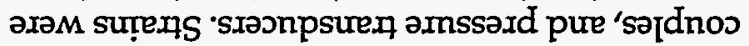
-our.ว

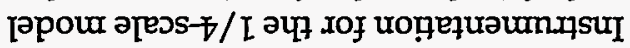

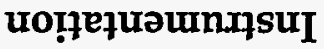

8uruado asourng

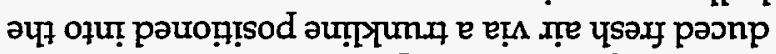

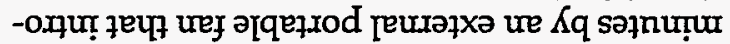
SI xof pa8.md әxәм sase 8 uogeuofop-7so d roop

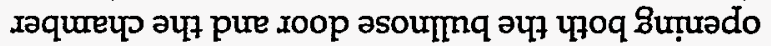

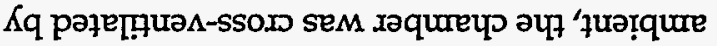

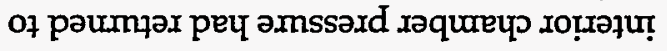

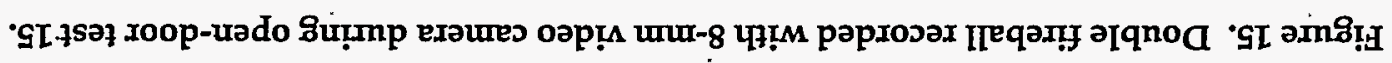

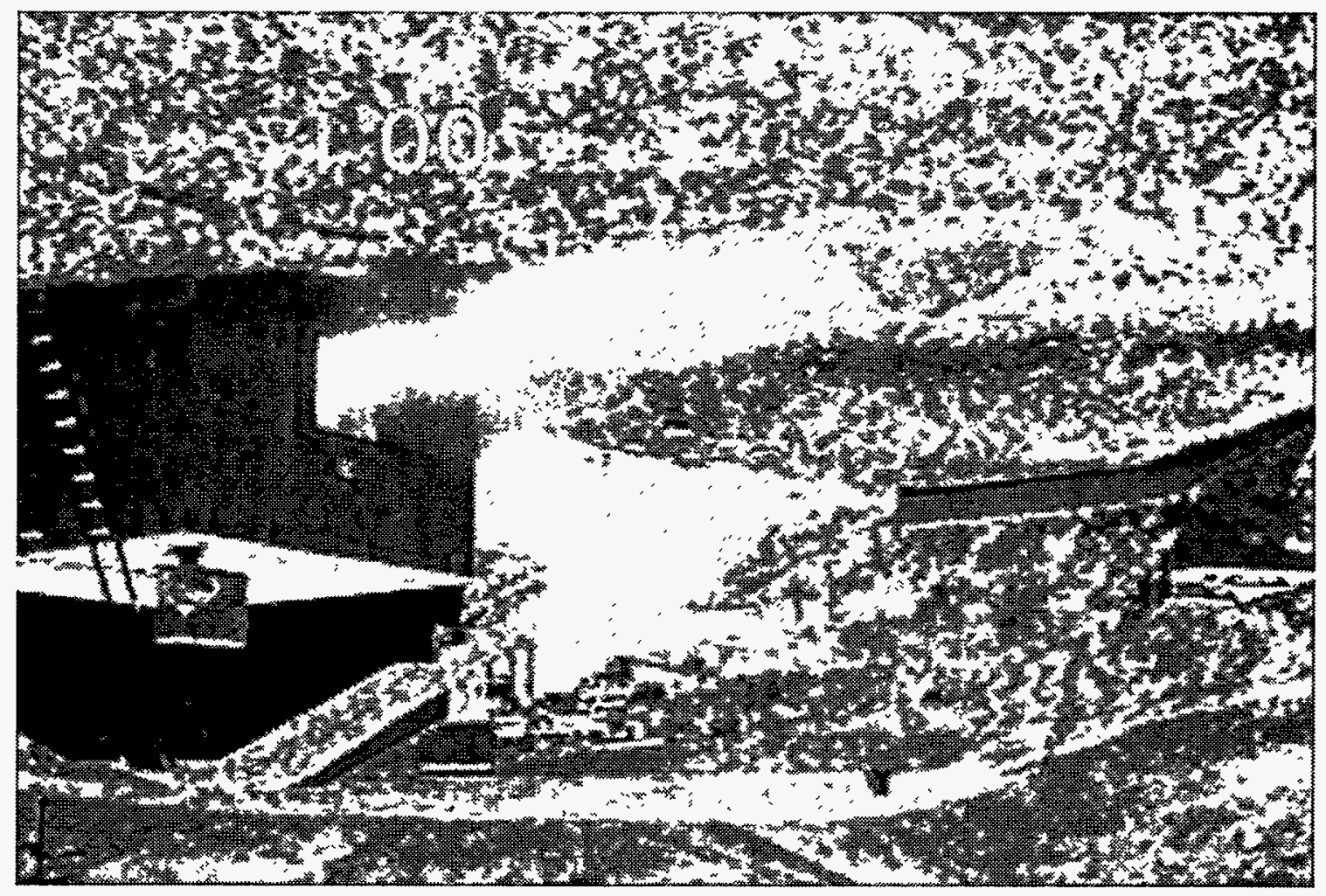




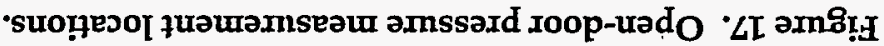

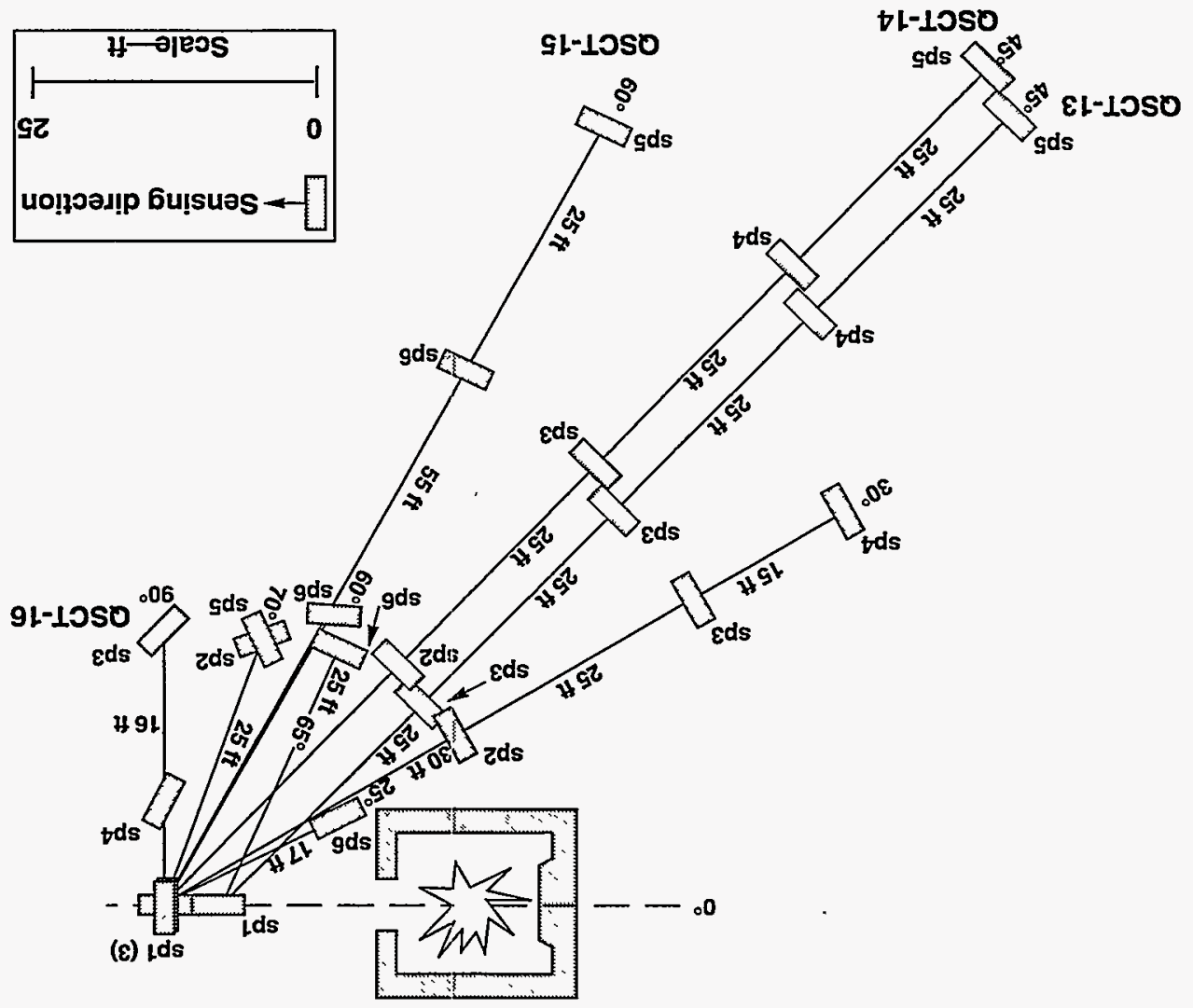

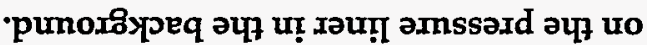

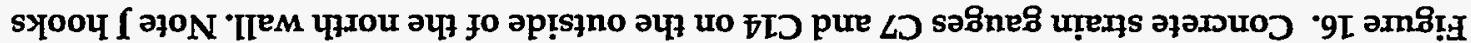

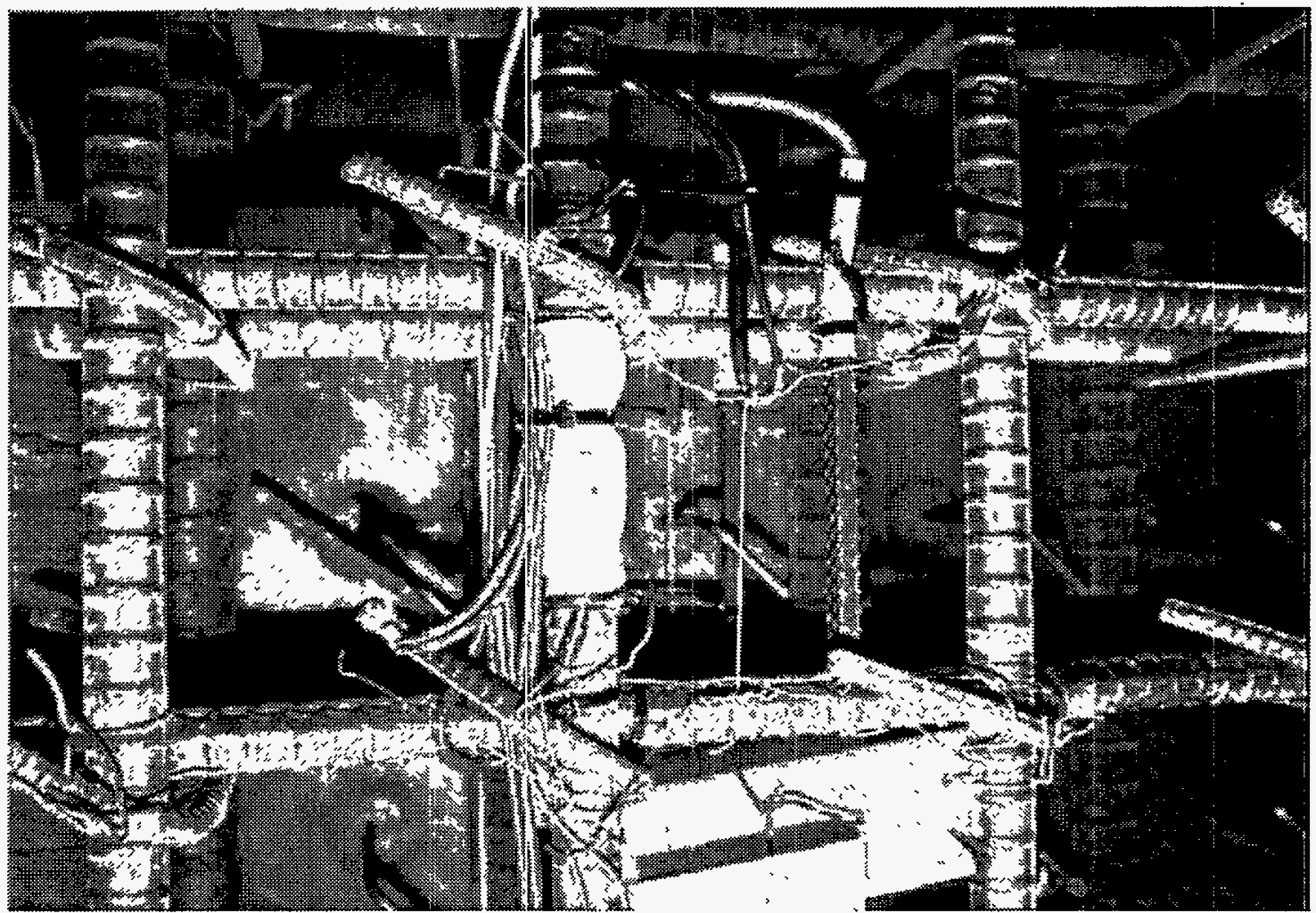


Table 3. Closed-door testing instrumentation.

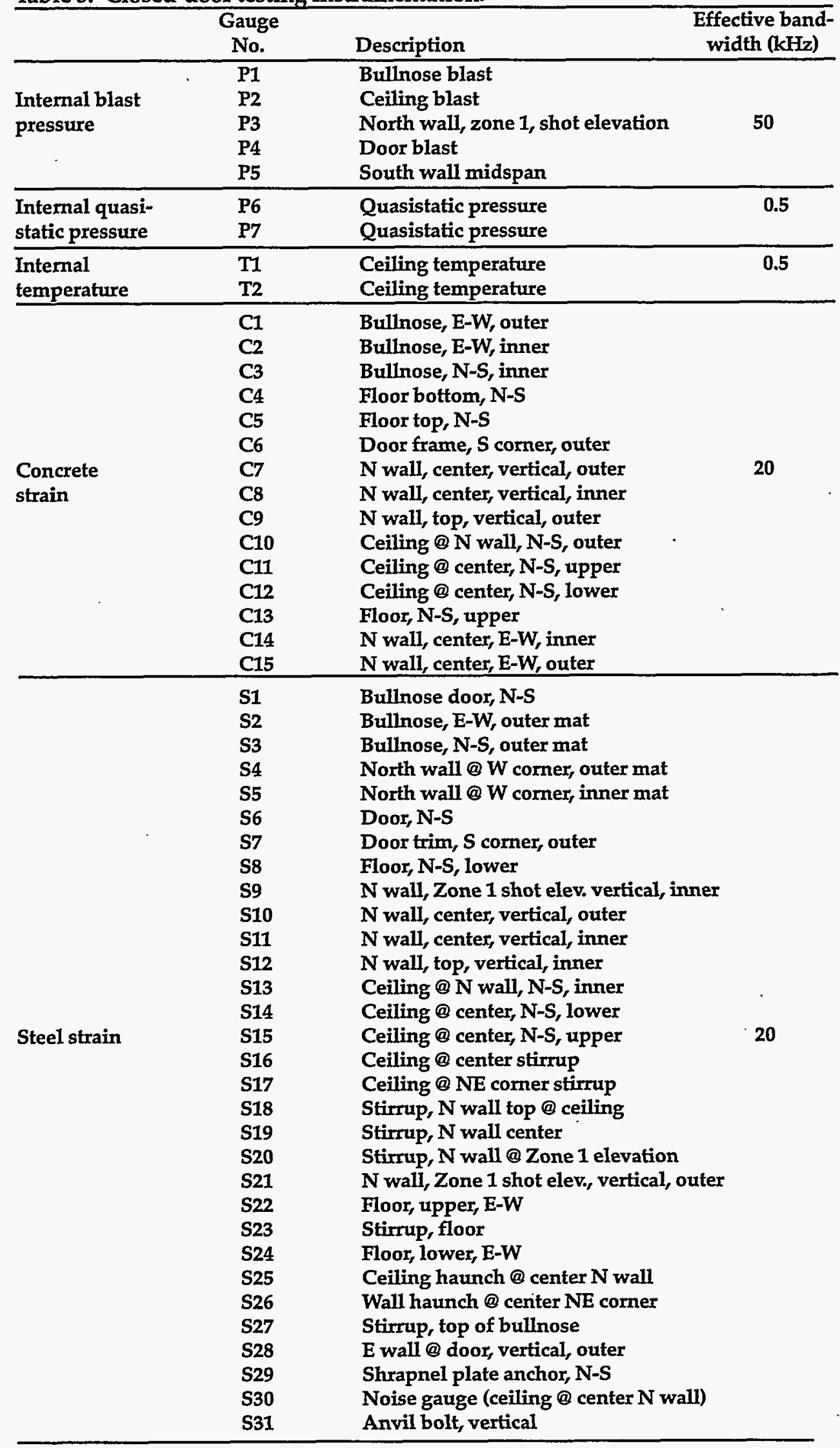


chipping away the concrete cover to a depth of about $1.5 \mathrm{in}$. thick by $6 \mathrm{in}$. across. Then the new gauges and their signal wires were sealed against moisture and protected with a 1/4-in.-thick steel plate. No attempt was made to patch the chipped-away concrete. The foil replacement gauges performed flawlessly for the remainder of the tests. Due to budgetary restrictions, the failed gauges were not removed and dissected. The most widely held theory for their failure is corrosion within their stainless-steel jackets.

\section{Empirical Results}

From the 16 experiments conducted in the 1/4-scale model, 44 million data points were collected from 880 time-series data records. This data, scaled in engineering units, has been archived in ASCII on an RCD-rom in ISO-9660 format, which is readable by Apple Macintosh computers and PCs. Because the amount of data is so large, only the maximum levels recorded from the 16 tests are presented in this report. For the closed-door tests, maximum tensile and compressive strains have been analyzed and are tabulated in Tables A1 and A2 of Appendix A. From the maximum measured strains in Tables $\mathrm{A} 1$ and $\mathrm{A} 2$, the corresponding maximum tensile and compressive stresses have been calculated and are shown in Tables A3 and A4. Material properties listed in Table 4 were used to calculate the maximum stresses from the measured maximum strains. To access and evaluate the original nonyielding criteria, safety factors for tensile and compressive dynamic yielding based on the Table 4 properties were calculated and are listed in Tables A5 andA6. Safety factors less than $I$ indicate yielding and are shown in bold for graphical comparison.

Peak external blast pressures from the opendoor tests are summarized in Fig. 18. Peak internal blast pressures from each data record are tabulated in Table 5. Typical internal blast pressure traces recorded from the $100 \%$ charge levels for the bullnose and the south wall are shown in Figs. 19 and 20, respectively.

Figure 21 shows quasistatic gas pressure and corresponding average air temperature from a $125 \%$ over-test in Zone 1. While it was intended to measure only the quasistatic gas pressure, the pressure transducer also was exposed to the more impulsive high-pressure shock waves. This is believed to have excited an internal resonance within the transducer that produced a false overshoot and ringing for the first 10 seconds. The trace in Fig. 21a has been filtered to remove erroneous ringing and overshoot.

Table 4. Material properties and acceptable strain levels.

\begin{tabular}{lccc}
\hline \multirow{2}{*}{ Category } & $\begin{array}{c}\text { Elastic modulus } \\
\left(10^{6} \mathrm{psi}\right)\end{array}$ & \multicolumn{2}{c}{ Microstrain at dynamic yield } \\
\cline { 3 - 4 } & 30.00 & Tensile & Compressive \\
\hline Bolts & 29.00 & 1500 & 1500 \\
Rebar & 4.68 & 2586 & 2586 \\
Concrete & 30.00 & 125 & 1410 \\
Doors & & 1500 & 1500 \\
\hline
\end{tabular}




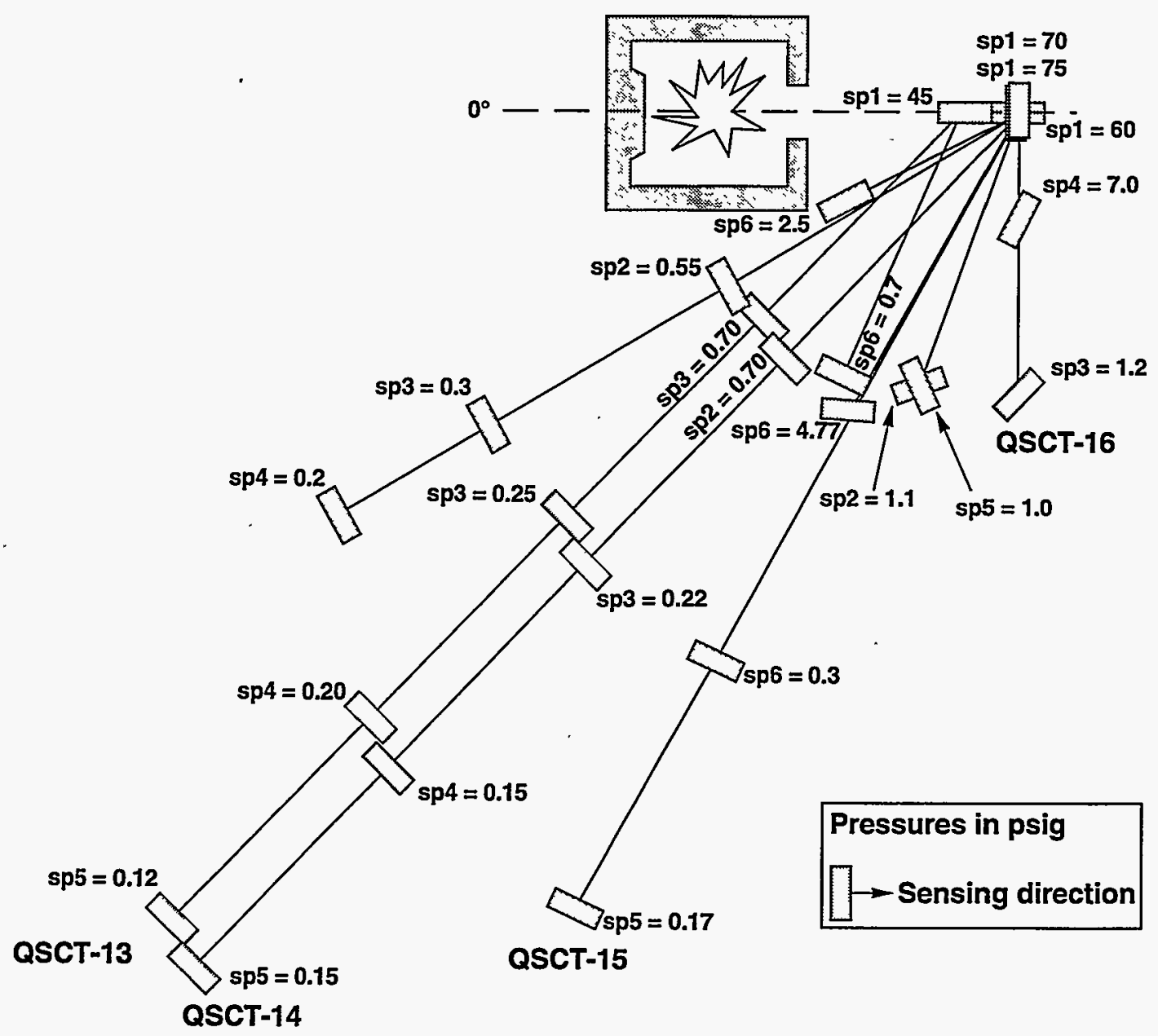

Figure 18. Open-door test pressures map.

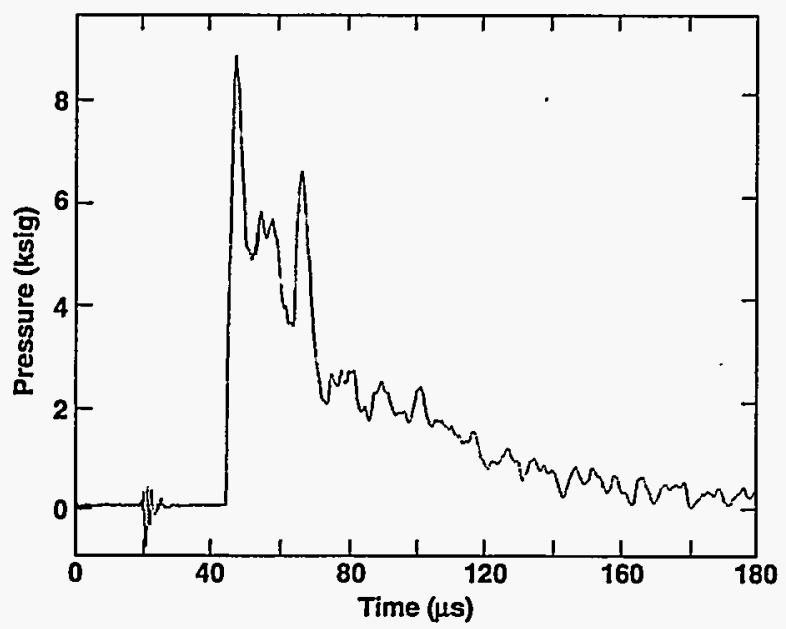

Figure 19. Typical close-in blast pressure trace on bullnose from $100 \%$ charge in Zone 4 (test 9).

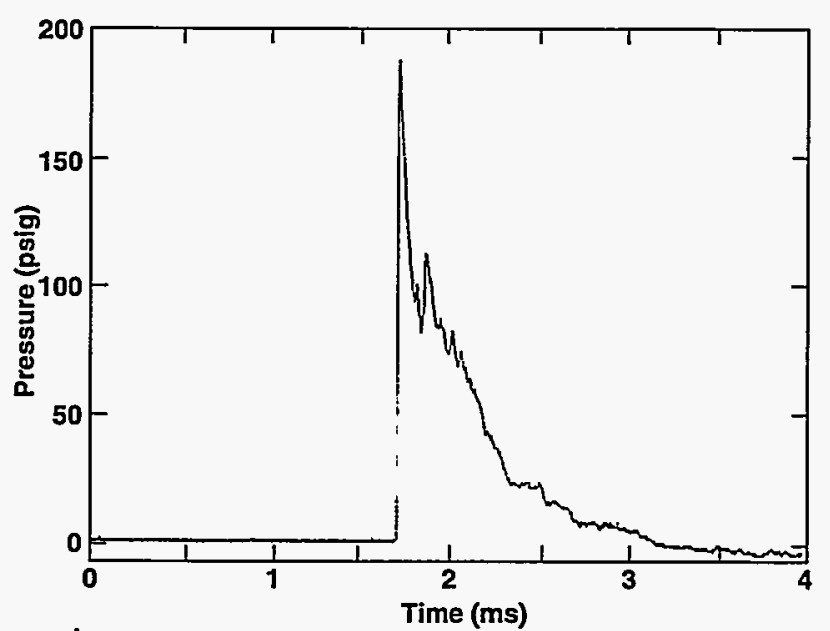

Figure 20. Typical far-range blast pressure trace on south wall from $100 \%$ charge in Zone 1 (test 8 ). 
Table 5. Maximum internal blast pressures (psig).

\begin{tabular}{|c|c|c|c|c|c|c|c|c|c|c|c|c|c|}
\hline Test No. & & 1 & 2 & 3 & 4 & 5 & 6 & 7 & 8 & 9 & 14 & 15 & 16 \\
\hline Shot series QSCT- & & 2 & 3 & 1 & 5 & 6 & 4 & 8 & 9 & 7 & 10 & 11 & 12 \\
\hline C4 explosive wt (lb) & & 0.52 & 0.52 & 0.3 & 1.03 & 1.03 & 0.6 & 2.07 & 2.07 & 1.21 & 1.51 & 2.58 & 2.58 \\
\hline$\%$ of full-scale chg. & & & 25 & & & 50 & & & 100 & & & 125 & \\
\hline Zone & & 1 & 1 & 4 & 1 & 1 & 4 & 1 & 1 & 4 & 4 & 1 & 1 \\
\hline Bullnose & P1 & - & - & 3612 & 318 & 282 & 1686 & 550 & 420 & 8723 & 15,322 & - & - \\
\hline Ceiling & P2 & - & 38 & 33 & - & - & - & 77 & 102 & 79 & 94 & 185 & 188 \\
\hline North wall, zone 1 shot elev. & P3 & - & 61 & - & 211 & 218 & 65 & 1185 & 305 & 201 & 133 & 445 & 423 \\
\hline Door & P4 & - & 64 & - & 323 & 707 & 139 & 1259 & 335 & 100 & - & 1138 & 267 \\
\hline South wall, midspan & P5 & - & 45 & 15 & 115 & 93 & 51 & 190 & 186 & 76 & - & 217 & 230 \\
\hline
\end{tabular}

(-) indicates data not available
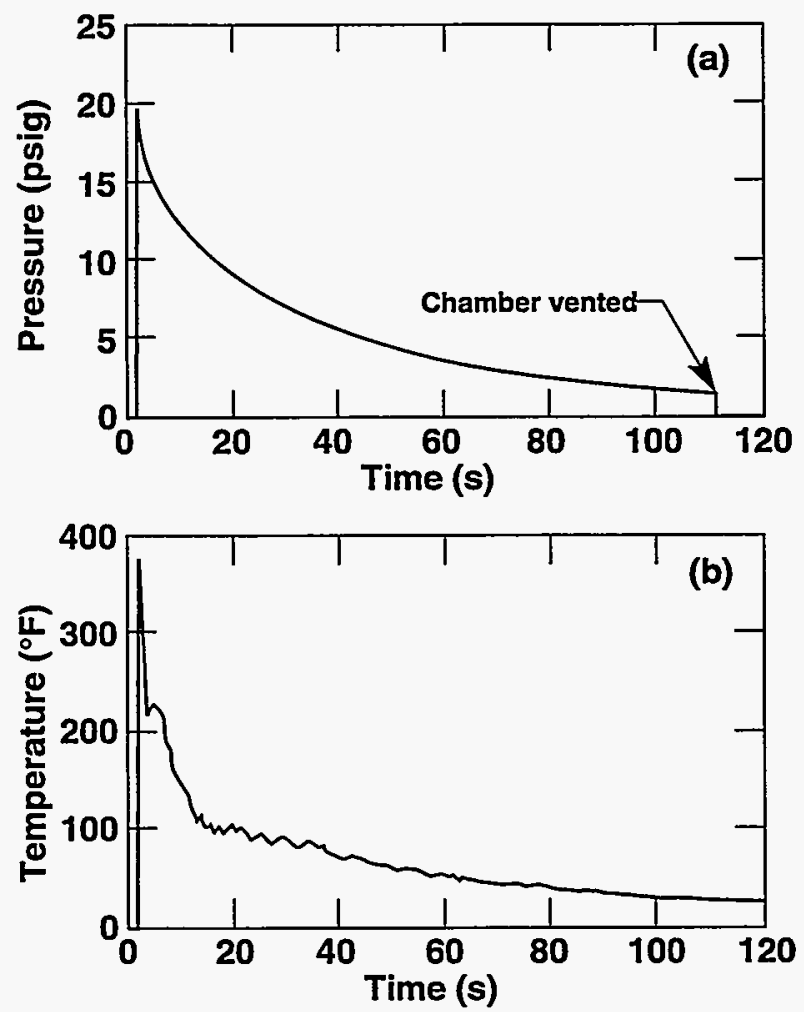

Figure 21. Typical quasistatic gas pressure and temperature records for closed door tests with $125 \%$ charges detonated in Zone 1.

\section{Observations and Conclusions}

1. From the safety factors for dynamic compressive yield (see Table A6), no problem is apparent in the steel reinforcement or the concrete as long as the members are in compression. Safety factors calculated from the $100 \%$ and $125 \%$ testing levels range from 2.6 to 647 , the worst case $(\mathrm{SF}=2.6)$ being in the concrete at the center of the ceiling near the inner reinforcing mat (C12).

2. Based on the safety factors for dynamic tensile yield, no problem is apparent in the steel reinforcement. However, at seven distinct gauge locations within the concrete, the safety factors for dynamic tensile yielding were less than 1.0. This is particularly evident in the data for the $100 \%$ and $125 \%$ testing levels in Table A5. The implication is that blast-induced cracking of the concrete is likely to initiate in these areas. The areas of concern are the center spans of the north wall and ceiling. Because the firing chamber is symmetrical, the following observations for the north wall also would apply to the south wall.

Specifically, at $100 \%$ and $125 \%$, the vertical strain in the north wall outer concrete center span (C7) exceeded dynamic yield four out of six times, giving consistently low safety factors $(0.86$ to 0.66 ). For only one experiment out of six did the inner concrete gauge in this same area produce an unacceptable SF of 0.96 . In the horizontal direction (east-west), the inner concrete gauge (C14) indicated yielding $(\mathrm{SF}=0.93$, 0.80 ) and only for the two Zone- 1 experiments at the $100 \%$ level. At the $125 \%$ level, the safety factors for gauge C14 increased to 1.81 and 1.69 for Zone 1.

Similarly low safety factors $(0.84,0.87)$ were measured in the upper concrete of the ceiling 
(C11) for the two $100 \%$ test levels in Zone 1. At the $125 \%$ level, the safety factors for the outer concrete had increased to 1.32 and 1.24. This appears to be at the expense of the inner concrete (C12) safety factors, which then deceased to 0.95 and 0.88 . From these observations, it is assumed that cracking of the concrete in the ceiling initiated at the outer surface and eventually advanced through the ceiling to the inner surface. To enhance the visual effects of the cracks, the concrete was moistened and photographed during different stages of drying before the $125 \%$ shot level. Figures 22-24 show typical cracks from the dynamic response of the firing chamber.

3. Low safety factors for dynamic tensile yielding $(\mathrm{SF}=0.71,0.72)$ also were recorded on gauge $\mathrm{C} 6$, located in the concrete near the corners of the door frame during tests 9 and 15. This observation is assumed to be less important, inasmuch as the details for the extra reinforcement in this region were not fully specified in the $\mathrm{CDR}$, and high localized strains were expected.

4. At the $50 \%$ shot level, low tensile safety factors for dynamic yielding $(\mathrm{SF}=0.91,0.97)$ were recorded in the bottom of the concrete floor. This was consistent with the results from previous testing. ${ }^{13}$ When a previously developed blast- attenuation system was used for the remaining 10 experiments above the $50 \%$ level, the lowest factor of safety was 2.08 for the $125 \%$ level. Figure 25 shows the floor blast attenuation system in place.

5. Based on the measured strain in a single anvil hold-down bolt in Zone 1 (gauge S31), it is recommended that the number of anvil holddown bolts be increased. It appears that significant rebounding of the anvil occurs, which induces very high tensile forces and yielding in the hold-down bolts. Tensile safety factors as low as 0.27 were measured at the $100 \%$ level. Additionally, by adding more bolts and thus decreasing the spacing between bolts, the tensile rebound forces are expected to be spread out more uniformly within the concrete below the anvil. The transfer of these tensile rebound forces into the concrete through an insufficient number of anchor bolts is speculated to cause highly localized yielding, leading to through-thickness cracking, as observed during the floor section testing. 13

6. As expected from cracked section concrete design, it appears that tensile yielding (i.e., cracking) of the concrete increases the damping of the vibrational response of the

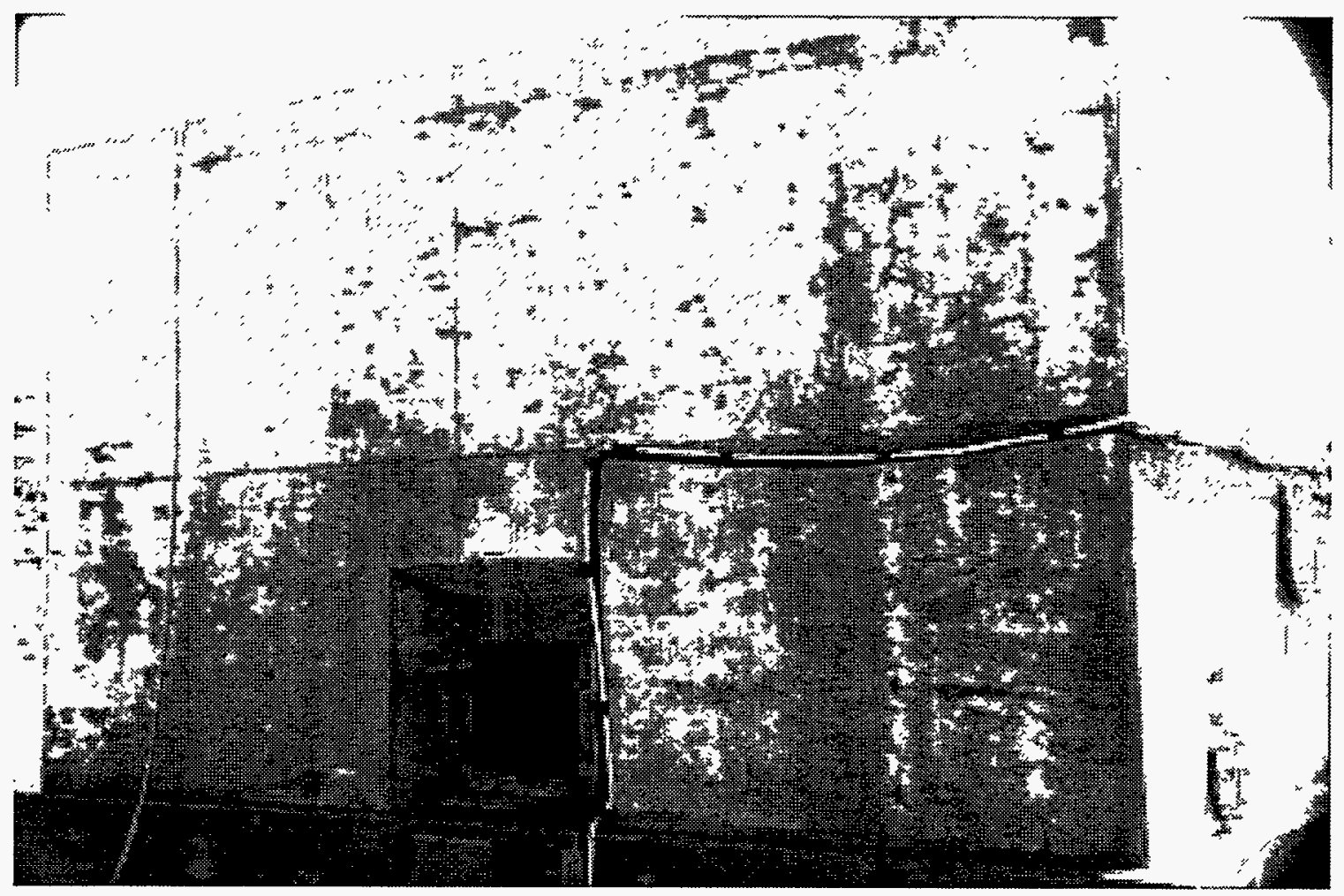

Figure 22. Exterior cracks on bullnose (west) side of chamber after $100 \%$ level shots. 


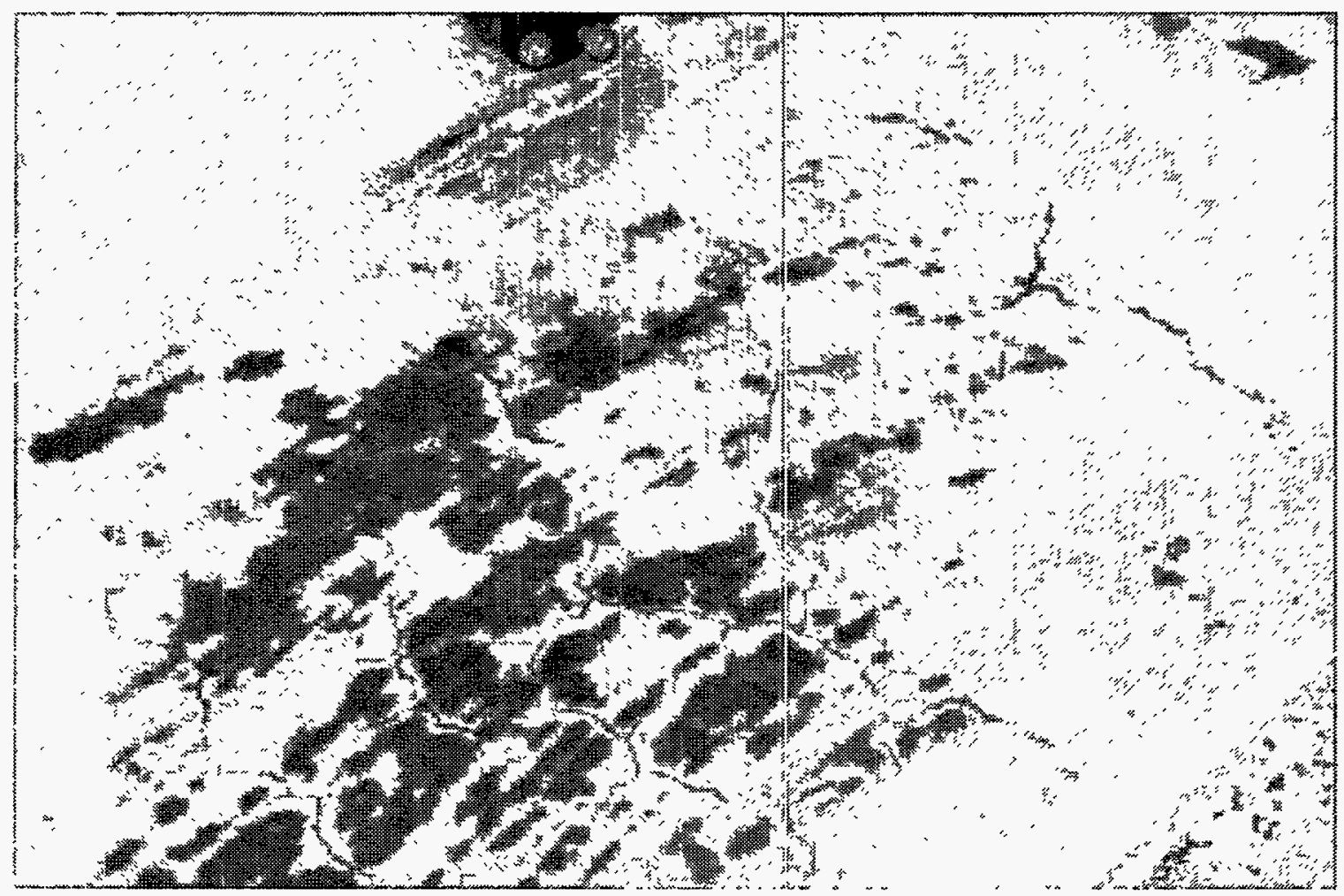

Figure 23. Interior cracks in floor between anvil and north wall.

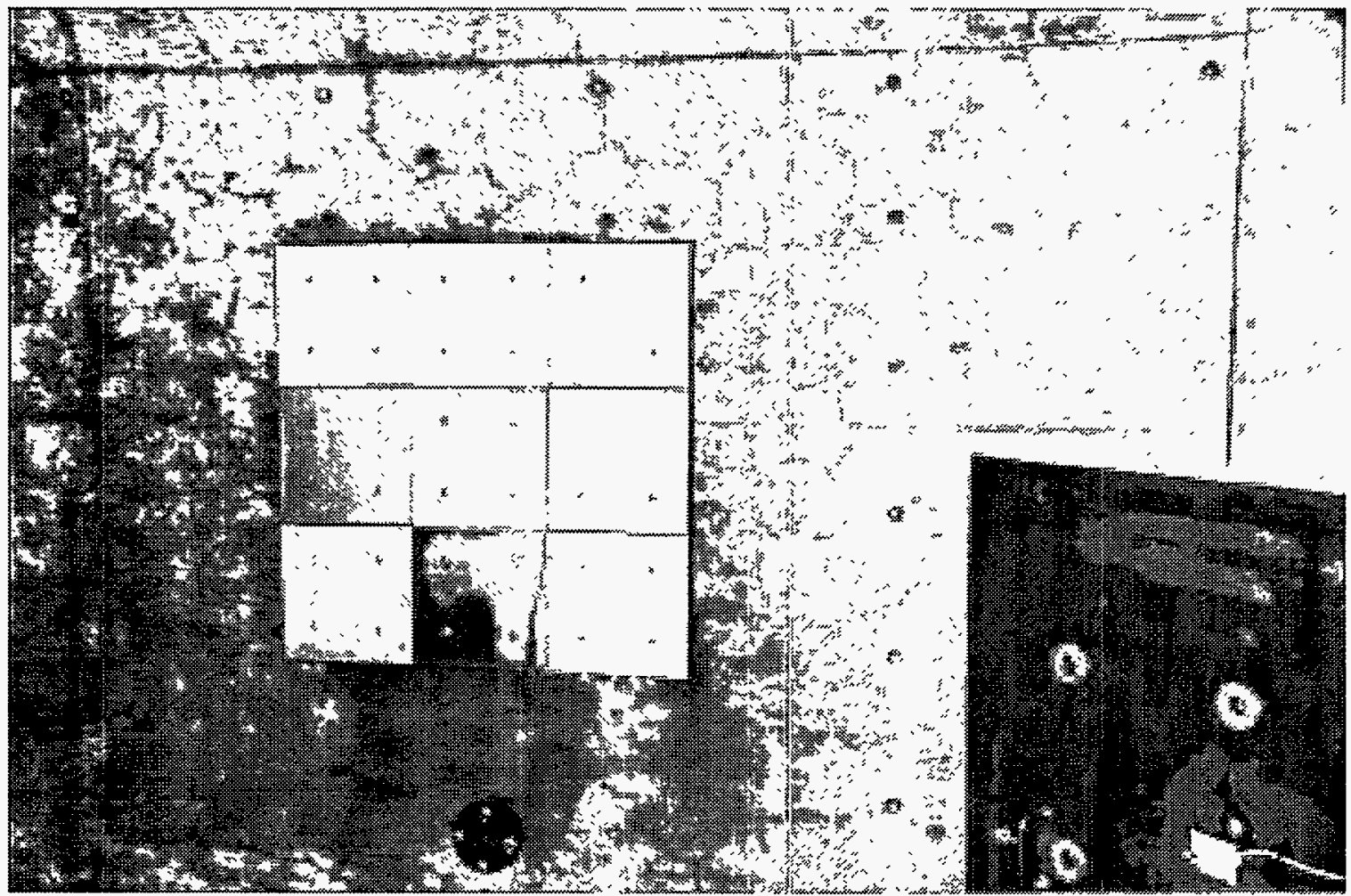

Figure 24. Interior cracks in north wall after $100 \%$ charge level experiments. 


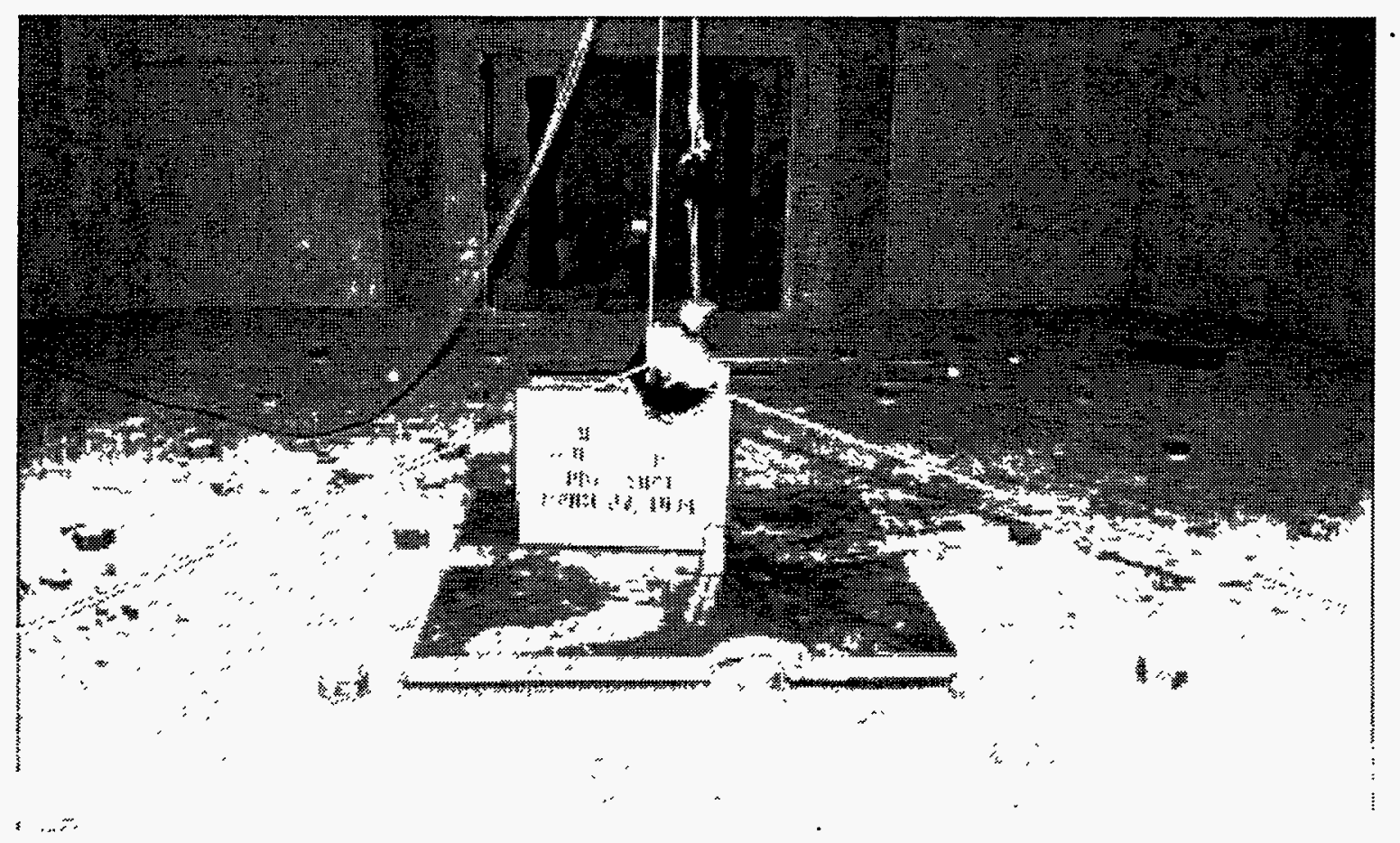

Figure 25. Blast attenuation system between explosive charge and the floor anvil.

structure. This can be seen by examining Fig. 26, which gives a chronological history of the strain in the concrete of the north wall (gauge C7) prior to and during yielding. This figure also gives evidence of strain relaxation and redistribution by the reduction in the peak strain value from (a) to (b). It is not clear that this cracked section behavior is desirable from a repeated use standpoint, in that it may not be compatible with the original design criteria of an infinite-life elastic response. Clearly, the long-term behavior after cracking has not been tested in these experiments, and further study is recommended.

7. Various high-temperature coatings were applied to the nine mild-steel shrapnel-protection plates mounted within the north inside wall of the chamber. Table 6 lists these coatings by surface preparation and manufacturer's name. These coatings, which were all at a scaled distance of approximatley $4.5 \mathrm{ft} / \mathrm{lb}^{1 / 3}$ from a charge in Zone 1, performed equally well and did not show any signs of burning from the detonation fireball.

High-temperature paint was also applied to the inside surface of the bullnose door, which was located at a scaled distance of $0.73 \mathrm{ft} / 1 \mathrm{lb}^{1 / 3}$ from Zone 4. Because it was close to the charge, the paint showed some signs of ablation and burning.

8. Unexpectedly, about half of the steel rebar strain gauges failed just before and just as testing started. Although this was unfortunate, we overcame this condition by replacing strain gauges during mid-testing and successfully obtained rebar strain at important points (see Fig. 27). Since similar strain gauges are planned to be used in the full-size chamber to monitor its dynamic response over its lifetime, it is recommended that these failures be investigated to determine the exact cause so that they may be prevented in the future.

9. The measured peak internal blast pressures were compared with those calculated by using the SHOCK ${ }^{14}$ computer program at the $100 \%$ shot level for detonations in Zones 1 and 4. The SHOCK computer program was the program used in the CDR to calculate the load pressures and impulses for the design of the chamber. For comparison, Table 7 compares measured and predicted. For close-in loading at scaled distances less than $1.0 \mathrm{ft} / \mathrm{lb}^{1 / 3}$, the measurements are close to those predicted $(\sim 85 \%)$. In the far 

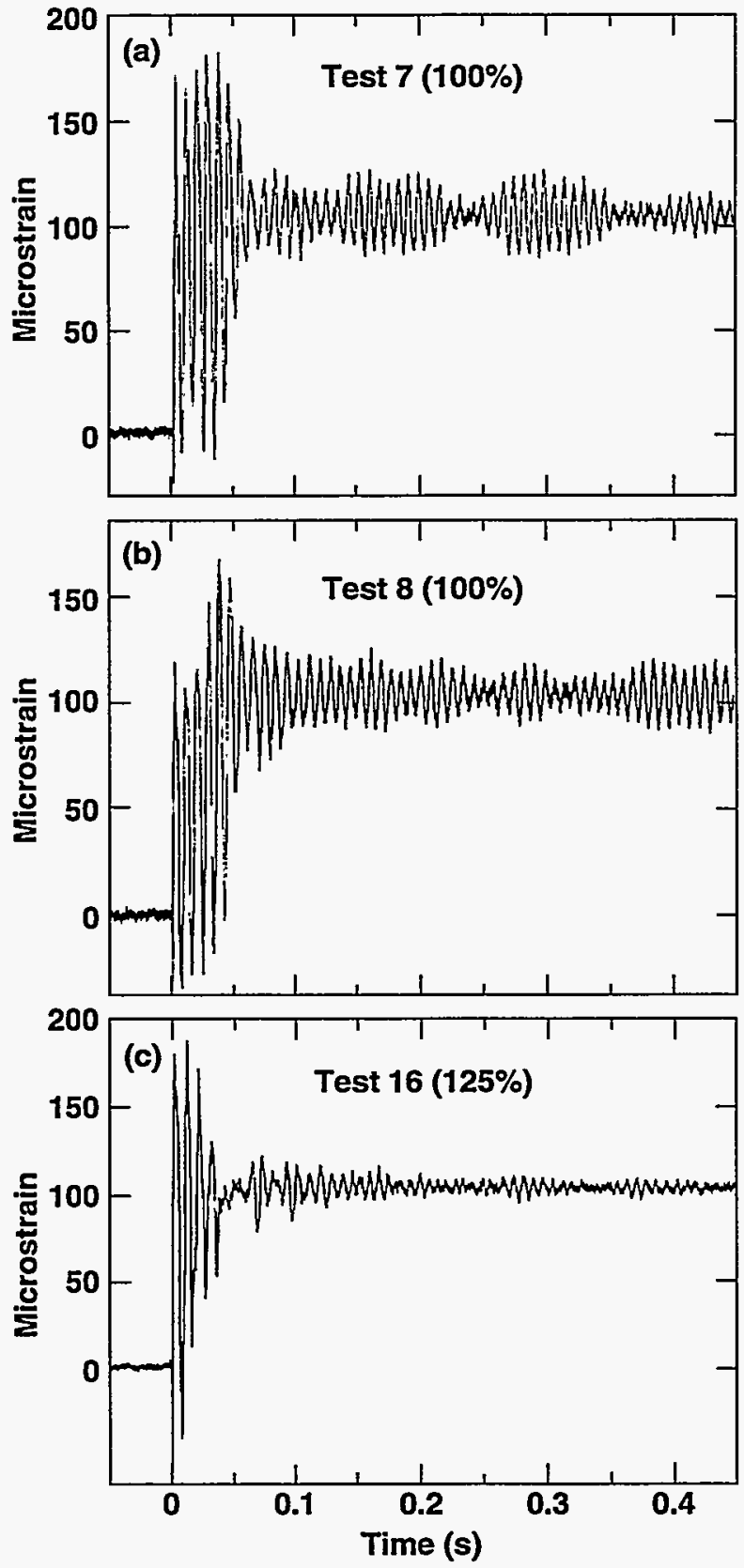

Figure 26. Damping increased, possibly because of cracking in the concrete in the north wall of the chamber (gauge $\mathrm{C7}$ ).
Table 6. High-temperature coatings used on shrapnel protection plates.

1. Degreased, Rust Knock Out primer, white Break-Through latex enamel

2. Sandblasted, Brinner 565 undercoat only

3. Sandblasted, Steelit 2203 undercoat, Steelit Anti-Rust stainless-steel coating

4. Degreased, Steelit 2203 undercoat, Steelit Anti-Rust stainless-steel coating

5. Sandblasted, metallic ceramic coating

6. Sandblasted, Northwestern Industries \#2

7. Sandblasted, Northwestern Industries \#1

8. Sandblasted, copper plated, bright nickel plating

9. Degreased, white Break-Through enamel

range loading regime, the measurements are, on average, 2.8 times higher than those predicted by SHOCK. The most likely explanation for this large cliscrepancy is the use of electrician's tape over the face of the pressure sensing diaphragm to eliminate the temperature effects from the fireball. In doing so, the presence of the tape may have mass-loaded the sensor and thus changed its effective calibration.

10. Figure 28 shows a reasonable correlation of the peak values for measured quasistatic pressure and temperature as a function of charge weight. As expected, the quasistatic pressure is due to the hot products of combustion and it decreases at the same rate as the gases cool (see Fig. 21).

11. The quasistatic gas pressure measured during the experiments tracked the predicted pressures fairly well. Figure 29 is a plot of the peak values of the quasistatic pressures as a function of the charge weights used. At the $125 \%$ shot level, the measured pressure was 18 psig vs 21 psig calculated via the Weibell formula.

Table 7. Comparison of measured and predicted internal blast pressures for $100 \%$ full-scale charge.

\begin{tabular}{|c|c|c|c|c|c|c|c|}
\hline \multirow[b]{2}{*}{ Location } & \multirow[b]{2}{*}{ Gauge } & \multicolumn{2}{|c|}{$\begin{array}{c}\text { Measured data* } \\
\text { (psig) } \\
\text { Shot zone } \\
\end{array}$} & \multicolumn{2}{|c|}{$\begin{array}{l}\text { SHOCK program } \\
\text { prediction (psig) } \\
\text { Shot zone } \\
\end{array}$} & \multicolumn{2}{|c|}{$\begin{array}{l}\text { Measured - } \\
\text { predicted } \\
\text { Shot zone }\end{array}$} \\
\hline & & 1 & 4 & 1 & 4 & 1 & 4 \\
\hline Bullnose & P1 & 420 & 8723 & 138 & 10,258 & 3.04 & 0.85 \\
\hline Ceiling & $\mathrm{P} 2$ & 102 & 79 & 124 & 34 & 0.82 & 2.32 \\
\hline North wall, zone 1 shot elev. & P3 & 305 & 201 & 138 & 41 & 2.21 & 4.93 \\
\hline Door & P4 & 335 & 100 & 136 & 21 & 2.46 & 4.67 \\
\hline South wall, midspan & P5 & 186 & 76 & 56 & 39 & 3.31 & 1.93 \\
\hline
\end{tabular}

*Measured data from tests 8 and 9. 


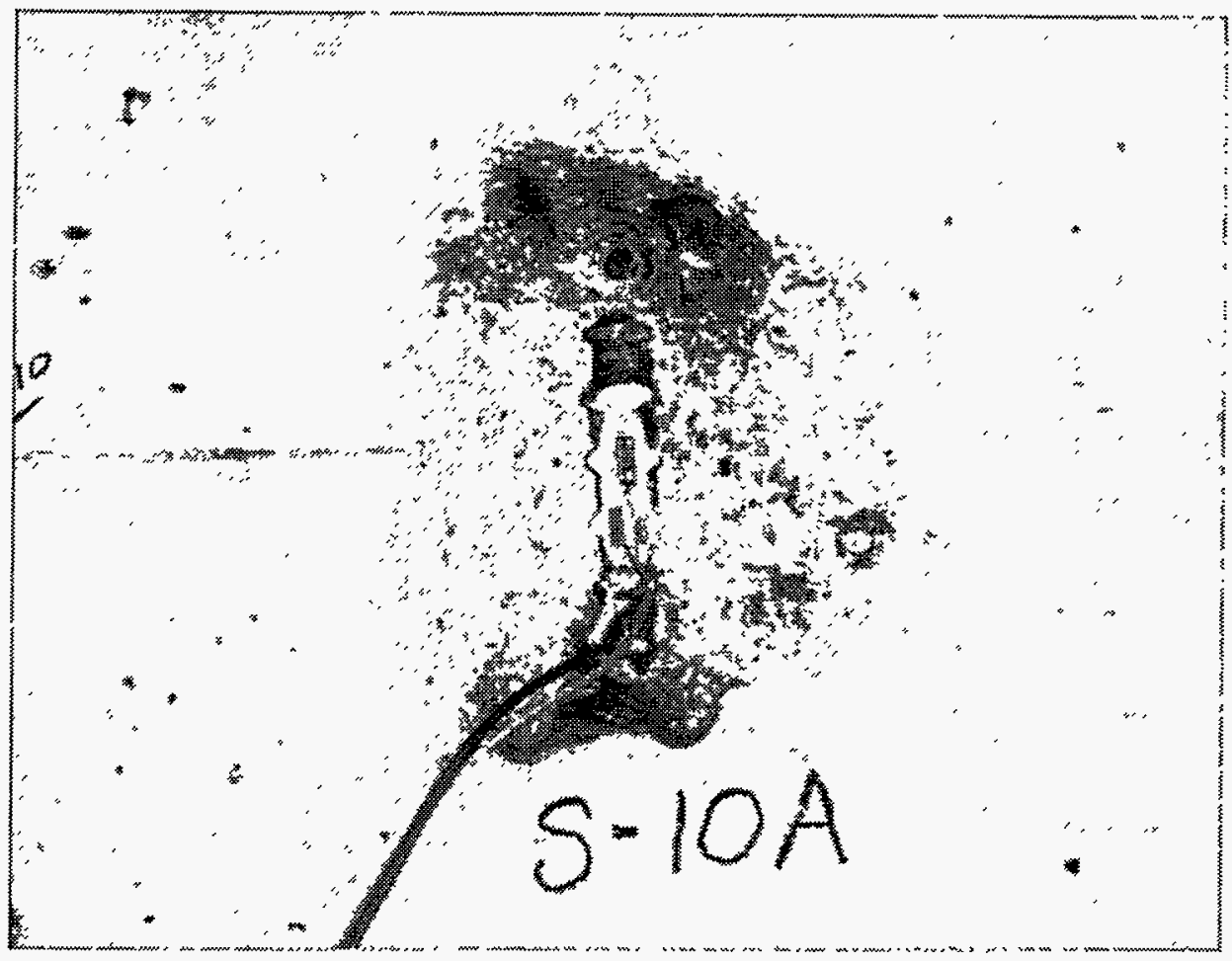

Figure 27. Replacement strain gauge added to rebar after concrete was cured.

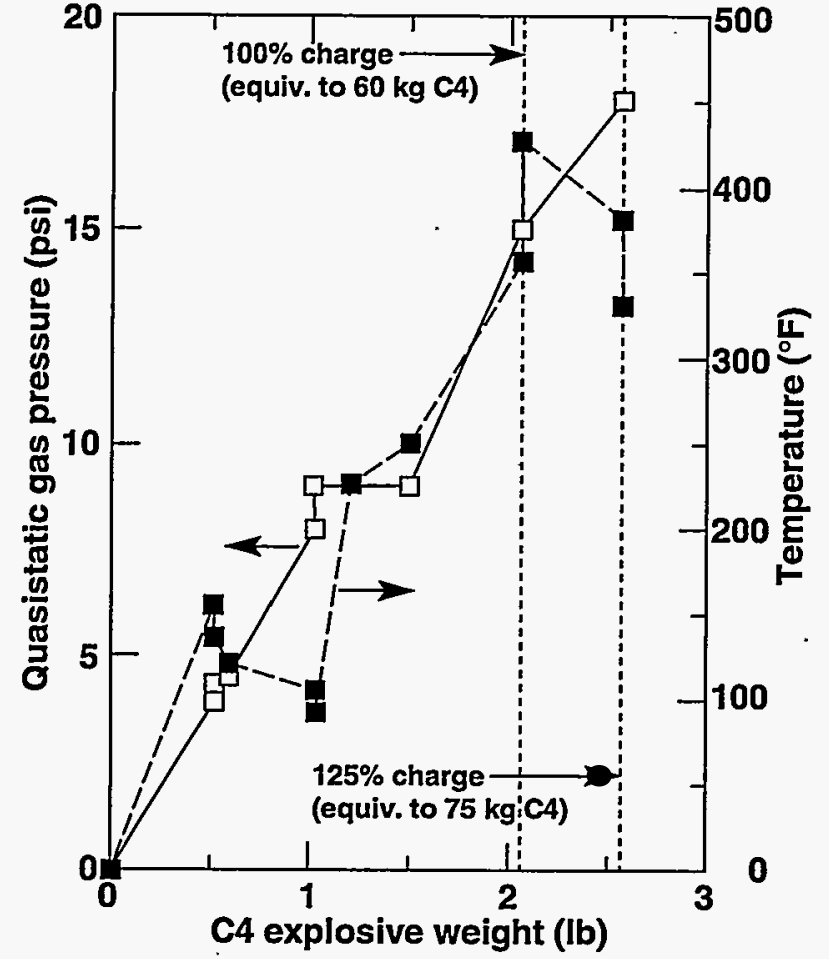

Figure 28. Correlation between peak quasistatic pressure and temperature for the 1/4-scale model as a function of charge weight.

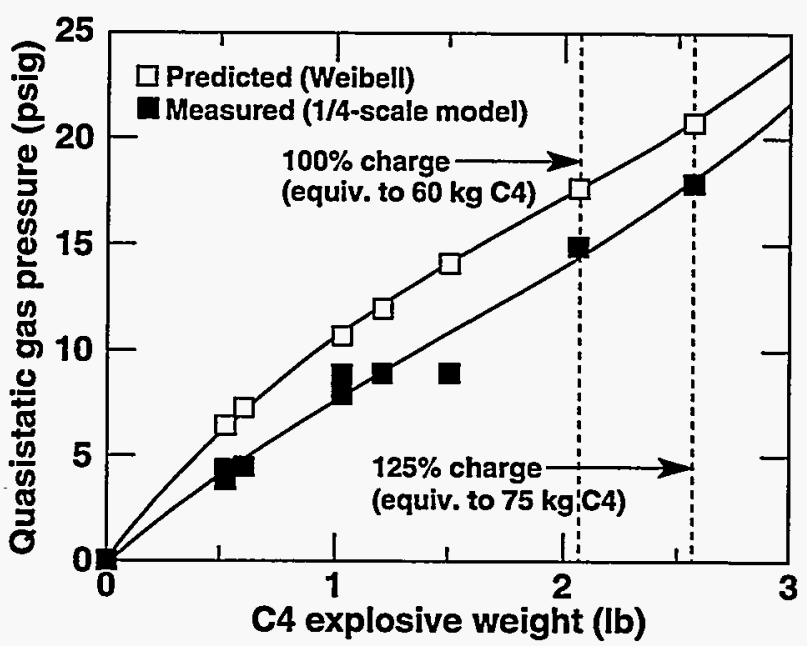

Figure 29. Comparison of predicted and measured quasistatic gas pressure for the $1 / 4$-scale model as a function of charge weight. 


\section{Notes and References}

1. The design of this facility is governed by DOE requirements and regulations found in DOE 5481.1B, DOE 5430.1A, DOE 6430.1A, DOE/AD-0006/1, DOE/EV-0043, DOE/EV-06194 (DOE Explosives Safety Manual), DOE/NEPA, and 10CFR Part 435 (Energy Conservation Report).

2. Composition of HMX: octahydro-1,3,5,7-tetranitro-1,3,5,7-tetrazocine.

3. Structures to Resist the Effects of Accidental Explosions, Joint Departments of the Army, the Navy, and the Air Force, TM5-1300/NAVFAC P-397/AFR 88-22 (Nov. 1990).

4. Site 300 Contained Firing Facilities-Conceptual Design Report, U.S. Department of Energy Project Number 94-SAN-LLN-02, prepared by Holmes \& Narver Architects-Engineers, Sept. 1992.

5. J. W. Pastrnak, C. F. Baker, and L. F. Simmons, Shrapnel Protection Testing in Support of the Proposed Site 300 Contained Firing Facility, Lawrence Livermore National Laboratory, UCRL-ID-110732 (1992).

6. J. W. Pastrnak, C. F. Baker, and L. F. Simmons, Quarter Scale Close-in Blast Loading Experiments in Support of the Planned Contained Firing Facility, Lawrence Livermore National Laboratory, UCRL-JC116822 (1994).

7. Health \& Safety Manual, Lawrence Livermore National Laboratory, Livermore, CA, M-010 (1990), Ch. 6.26.

8. The High-Explosives Applications Facility can detonate up to $10 \mathrm{~kg}$ of high explosive in stainless-steel firing vessels.

9. Soils Inspection Report, Consolidated Engineering Laboratories, Pleasanton, CA, PFN \# 812-93001 (1992).

10. Moisture Density Relations Test Report, Consolidated Engineering Laboratories, Pleasanton, CA, PFN \# 812-93001 (1992).

11. Concrete Compression Test Data, Consolidated Engineering Laboratories, Pleasanton, CA, PFN \#93004 (1-18-94) and (2-4-94).

12. Burke Metallic Spec. Grout, 9500 psi compressive strength, Burke Products Inc., San Mateo, CA.

13. J. W. Pastrnak, 1/4 Scale Model Project Plan (1993).

14. SHOCK Users Manual, Naval Civil Engineering Laboratory, Port Hueneme, CA, Version 1.0 (1988). 


\section{Appendix A Tabular Strain Data}

Table A1 Maximum tensile strains

Table A2 Maximum compressive strains

Table A3 Maximum tensile stresses

Table A4 Maximum compressive stresses

Table A5 Maximum tensile safety factors to yield

Table A6 Maximum compressive safety factors to yield 
Table A1. Maximum tensile strains ( $\mu$ in./in.).

\begin{tabular}{|c|c|c|c|c|c|c|c|c|c|c|c|c|c|}
\hline \multicolumn{2}{|c|}{$\begin{array}{l}\text { Test No.: } \\
\text { Test series (QSCT): } \\
\text { C4 explosive weight (lb): } \\
\text { \% of full-scale charge (zone): } \\
\text { Test date (1994): } \\
\quad \text { Gauge }\end{array}$} & $\begin{array}{c}1 \\
2 \\
0.52 \\
25(1) \\
3 / 18\end{array}$ & $\begin{array}{c}2 \\
3 \\
0.52 \\
25(1) \\
4 / 5\end{array}$ & $\begin{array}{c}3 \\
1 \\
0.3 \\
25(4) \\
4 / 5\end{array}$ & $\begin{array}{c}4 \\
5 \\
1.03 \\
50(1) \\
4 / 12\end{array}$ & $\begin{array}{c}5 \\
6 \\
1.03 \\
50(1) \\
4 / 12\end{array}$ & $\begin{array}{c}6 \\
4 \\
0.6 \\
50(4) \\
4 / 12\end{array}$ & $\begin{array}{c}7 \\
8 \\
2.07 \\
100(1) \\
4 / 27\end{array}$ & $\begin{array}{c}8 \\
9 \\
2.07 \\
100(1) \\
4 / 27\end{array}$ & $\begin{array}{c}9 \\
7 \\
1.21 \\
100(4) \\
4 / 27\end{array}$ & $\begin{array}{c}14 \\
10 \\
1.51 \\
125(4) \\
6 / 7\end{array}$ & $\begin{array}{c}15 \\
11 \\
2.58 \\
125(1) \\
6 / 7\end{array}$ & $\begin{array}{c}16 \\
11 \\
2.58 \\
125(1) \\
6 / 8\end{array}$ \\
\hline $\mathrm{C} 1$ & Bullinose, E-W, outer & 5 & 5 & 16 & 17 & 11 & 20 & 8 & 5 & 24 & 33 & 5 & 6 \\
\hline $\mathrm{C} 2$ & Bullnose, E-W, inner & 6 & 6 & 11 & 20 & 24 & 17 & 15 & 14 & 28 & 30 & 16 & 16 \\
\hline C3 & Bullnose, N-S, inner & 7.5 & 8 & 15 & 45 & 43 & 30 & 22 & 20 & 40 & 31 & 21 & 17 \\
\hline C4 & Floor bottom, N-S & 0 & 27 & 12 & 138 & 129 & 22 & 52 & 47 & 19 & 42 & 60 & 50 \\
\hline C5 & Floor top, N-S & 90 & 67 & 11 & 194 & 117 & 18 & 24 & 31 & 11 & 32 & 23 & 27 \\
\hline C6 & Door frame, $\mathrm{S}$ corner, outer & 0 & 49 & 32 & 65 & 65 & 63 & 96 & 103 & 176 & 110 & 174 & 123 \\
\hline $\mathrm{C} 7$ & $\mathrm{~N}$ wall, center, vertical, outer & 59 & 67 & 36 & 80 & 82 & 60 & 184 & 171 & 121 & 145 & 120 & 188 \\
\hline $\mathrm{C} 8$ & $\mathbf{N}$ wall, center, vertical, inner & 25 & 29 & 21 & 33 & 33 & 39 & 55 & 61 & 130 & 75 & 21 & 88 \\
\hline $\mathrm{Cg}$ & $\mathrm{N}$ wall, top, vertical, outer & 20 & 15 & 9 & 16 & 19 & 17 & 13 & 9 & 39 & 25 & 16 & 14 \\
\hline $\mathrm{C} 10$ & Ceiling $@ N$ wall, N-S, outer & 8 & 13 & 6 & 12 & 14 & 7 & 12 & 9 & 41 & 19 & 16 & 18 \\
\hline C11 & Ceiling @ center, N-S, upper & 58 & 68 & 38 & 96 & 101 & 49 & 148 & 143 & 76 & 71 & 95 & 101 \\
\hline $\mathrm{C} 12$ & Ceiling @ center, N-S, lower & 30 & 32 & 50 & 36 & 36 & 92 & 43 & 43 & 84 & 39 & 131 & 142 \\
\hline C13 & Floor, N-S, upper & 45 & 20 & 5 & 121 & 85 & 10 & 13 & 5 & 7 & 12 & 16 & 13 \\
\hline C14 & $\mathrm{N}$ wall, center, E-W, inner & 58 & 66 & 36 & 78 & 79 & 55 & 134 & 156 & 103 & 47 & 69 & 74 \\
\hline $\mathrm{C} 15$ & N wall, center, E-W, outer & 15 & 19 & 14 & 22 & 23 & 28 & 39 & 84 & 86 & 49 & 52 & 58 \\
\hline S1 & Bullnose door, N-S & 20 & 16 & 112 & 28 & 38 & 206 & 51 & 57 & 282 & 323 & 88 & 54 \\
\hline S2 & Bullnose, $E-W$, outer mat & 10 & 14 & 41 & 22 & 24 & 58 & 40 & 31 & 89 & 86. & 39 & 25 \\
\hline S3 & Bullnose, N-S, outer mat & 0 & 0 & 0 & 0 & 0 & $\mathbf{0}$ & 0 & 0 & 0 & 0 & $\mathbf{0}$ & $\mathbf{0}$ \\
\hline 54 & $N$ wall $@ W$ comer, outer mat & 22 & 26 & 17 & 38 & 34 & 37 & 57 & 63 & 52 & 48 & 72 & 82 \\
\hline S5 & $N$ wall $@ W$ corner, inner mat & 0 & 0 & 0 & 0 & 0 & $\mathbf{0}$ & 0 & $\mathbf{0}$ & 0 & $\mathbf{0}$ & $\mathbf{0}$ & $\mathbf{0}$ \\
\hline S6 & Door, N-S & 135 & 130 & 153 & 0 & 0 & 0 & 361 & 320 & 211 & 342 & 431 & 430 \\
\hline S7 & Door trim, $\mathrm{S}$ corner, outer & 38 & 38 & 26 & 63 & 61 & 63 & 127 & 150 & 171 & 226 & 44 & 216 \\
\hline S8 & Floor, N-S, lower & 35 & 0 & 0 & 0 & 0 & 0 & 0 & 0 & 0 & 0 & $\mathbf{0}$ & $\mathbf{0}$ \\
\hline S9 & $\mathrm{N}$ wall, Zone 1 shot elev., vert., inner & 0 & 0 & 0 & 0 & 0 & $\mathbf{0}$ & 0 & 0 & $\mathbf{0}$ & $\mathbf{0}$ & $\mathbf{0}$ & $\mathbf{0}$ \\
\hline S10 & $\mathrm{N}$ wall, center, vertical, outer. & 65 & 0 & 0 & 0 & 0 & 0 & 312 & 330 & 274 & 359 & 442 & 546 \\
\hline S11 & $\mathrm{N}$ wall, center, vertical, inner & 20 & 26 & 18 & 29 & 32 & 37 & 53 & 62 & 59 & 0 & 39 & 39 \\
\hline S12 & tical, inner & 45 & 0 & 0 & 0 & 0 & 0 & 0 & 0 & $\mathbf{0}$ & 0 & $\mathbf{0}$ & 0 \\
\hline S13 & Ceiling @N wall, $\mathrm{N}-\mathrm{S}$, inner & 90 & 101 & 74 & 146 & 148 & 117 & 336 & 367 & 225 & 266 & 289 & 362 \\
\hline S14 & Ceiling @ center, N-S, lower & 30 & $\mathbf{0}$ & 0 & 0 & 0 & 0 & 11 & 12 & 46 & 36 & 41 & 53 \\
\hline S15 & Ceiling @ center, $\mathrm{N}-\mathrm{S}$, upper & 70 & 75 & 75 & 0 & 0 & 0 & 218 & 284 & 0 & 0 & 351 & 343 \\
\hline S16 & Ceiling (1) center stirrup & 2 & 3 & 3 & 4 & 4 & 4 & 0 & $\mathbf{0}$ & 0 & 9 & 7 & 6 \\
\hline S17 & Ceiling @ NE co & 15 & 1074 & 939 & 35 & 20 & 20 & $\mathbf{0}$ & 0 & 0 & 0 & 36 & 44 \\
\hline S18 & Stirrup, $\mathrm{N}$ wall top @ ceiling & 3 & 8 & 5 & 10 & 20 & 10 & 16 & 22 & 8 & 7 & 18 & 23 \\
\hline S19 & Stirrup, $\mathbf{N}$ wall center & o & 3 & 4 & 6 & 6 & 4 & 7 & 12 & 9 & 13 & 18 & 19 \\
\hline $\mathbf{s} 20$ & $\mathrm{~N}$ wall @ Zone 1 elevation & 7 & 0 & 4 & 9 & 8 & 6 & 14 & 13 & 11 & 13 & 10 & 11 \\
\hline $\mathbf{S} 21$ & N wall, Zone 1 shot elev., vert, outer & 30 & 32 & 21 & 46 & 48 & 31 & 100 & 101 & 71 & 99 & 118 & 148 \\
\hline $\mathbf{s} 22$ & Floor, upper, E-W & 0 & 0 & $\mathbf{0}$ & 0 & $\mathbf{0}$ & $\mathbf{0}$ & $\mathbf{0}$ & 0 & 0 & $\mathbf{0}$ & $\mathbf{0}$ & 0 \\
\hline $\mathbf{S} 23$ & Stirrup, floor & 40 & 33 & $\mathbf{0}$ & $\mathbf{0}$ & 101 & 0 & 23 & 22 & $\mathbf{0}$ & 7 & 3 & 3 \\
\hline $\mathbf{S} 24$ & Floor, lower, E-W & 30 & 20 & 19 & 33 & 37 & 25 & 44 & 42 & 42 & 0 & 0 & 0 \\
\hline $\mathbf{S} 25$ & Ceiling haunch @ center $\mathbf{N}$ wall & 40 & 40 & 33 & 71 & 65 & 50 & 100 & 99 & 76 & 89 & 106 & 0 \\
\hline S26 & Wall haunch @ center NE corner & 0 & 0 & 0 & 0 & 0 & 0 & 131 & 162 & 125 & 117 & 169 & 146 \\
\hline $\mathbf{S 2 7}$ & Stirrup, top of bullinose & 7 & 9 & 9 & 18 & 14 & 15 & 10 & 10 & 23 & 28 & 21 & 22 \\
\hline $\mathbf{S} 28$ & E wall @ door, vertical, outer & 0 & $\mathbf{0}$ & 0 & $\mathbf{0}$ & 0 & 0 & $\mathbf{0}$ & 0 & 0 & 0 & 0 & 0 \\
\hline $\mathbf{S} 29$ & Shrapnel plate anchor, N-S & 225 & 288 & 139 & 482 & 485 & 303 & 614 & 500 & 0 & 0 & 0 & 0 \\
\hline S30 & Noise gauge (ceiling $\otimes$ center $\mathrm{N}$ wall) & 5 & 0 & 0 & $\mathbf{0}$ & 0 & 0 & 17 & 36 & 21 & 55 & 0 & 0 \\
\hline S31 & Anvil bolt, vertical & $\mathbf{0}$ & 1181 & 0 & 0 & 0 & 0 & 7136 & 7139 & 7301 & 0 & 0 & 0 \\
\hline
\end{tabular}


Table A2. Maximum compressive strains ( $\mu$ in./in.).

\begin{tabular}{|c|c|c|c|c|c|c|c|c|c|c|c|c|c|}
\hline \multicolumn{2}{|c|}{$\begin{array}{l}\text { Test No.: } \\
\text { Test series (QSCT): } \\
\text { C4 explosive weight (lb): } \\
\text { \% of full-scale charge (zone): } \\
\text { Test date (1994): } \\
\text { Gauge }\end{array}$} & $\begin{array}{c}1 \\
2 \\
0.52 \\
25(1) \\
3 / 18\end{array}$ & $\begin{array}{c}2 \\
3 \\
0.52 \\
25(1) \\
4 / 5\end{array}$ & $\begin{array}{c}3 \\
1 \\
0.3 \\
25(4) \\
4 / 5\end{array}$ & $\begin{array}{c}4 \\
5 \\
1.03 \\
50(1) \\
4 / 12\end{array}$ & $\begin{array}{c}5 \\
6 \\
1.03 \\
50(1) \\
4 / 12\end{array}$ & $\begin{array}{c}6 \\
4 \\
0.6 \\
50(4) \\
4 / 12\end{array}$ & $\begin{array}{c}7 \\
8 \\
2.07 \\
100(1) \\
4 / 27\end{array}$ & $\begin{array}{c}8 \\
9 \\
2.07 \\
100(1) \\
4 / 27\end{array}$ & $\begin{array}{c}9 \\
7 \\
1.21 \\
100(4) \\
4 / 27\end{array}$ & $\begin{array}{c}14 \\
10 \\
1.51 \\
125(4) \\
6 / 7\end{array}$ & $\begin{array}{c}15 \\
11 \\
2.58 \\
125(1) \\
6 / 7\end{array}$ & $\begin{array}{c}16 \\
11 \\
2.58 \\
125(1) \\
6 / 8\end{array}$ \\
\hline $\mathrm{Cl}$ & Bullnose, E-W, outer & 3 & 9 & 36 & 44 & 43 & 62 & 27 & 22 & 93 & 75 & 18 & 18 \\
\hline $\mathrm{C} 2$ & Bullnose, E-W, inner & 6 & 8 & 19 & 49 & 41 & 43 & 23 & 23 & 50 & 55 & 41 & 41 \\
\hline C3 & Bullnose, N-S, inner & 6 & 7 & 13 & 32 & 33 & 18 & 21 & 24 & 32 & 20 & 18 & 20 \\
\hline C4 & Floor bottom, N-S & 0 & 10 & 11 & 35 & 40 & 15 & 14 & 16 & 9 & 12 & 4 & 8 \\
\hline C5 & Floor top, N-S & 25 & 39 & 13 & 109 & 60 & 22 & 36 & 35 & 15 & 25 & 16 & 40 \\
\hline C6 & Door frame, S corner, outer & $\mathbf{0}$ & 27 & 20 & 21 & 25 & 34 & 40 & 51 & 50 & 25 & 70 & 85 \\
\hline $\mathrm{C7}$ & $\mathrm{N}$ wall, center, vertical, outer & 37 & 34 & 30 & 40 & 38 & 35 & 27 & 35 & 72 & 47 & 5 & 61 \\
\hline $\mathrm{C} 8$ & $\mathrm{~N}$ wall, center, vertical, inner & 30 & 35 & 21 & 37 & 41 & 36 & 77 & 69 & 119 & 49 & 133 & 74 \\
\hline $\mathrm{CP}$ & N wall, top, vertical, outer & 32 & 35 & 24 & 57 & 58 & 47 & 90 & 93 & 142 & $\pi 7$ & 103 & 110 \\
\hline $\mathrm{C} 10$ & Ceiling @N wall, $\mathrm{N}-\mathrm{S}$, outer & 14 & 19 & 11 & 25 & 24 & 18 & 31 & 35 & 55 & 28 & 44 & 57 \\
\hline C11 & Ceiling@ center, N-S, upper & 18 & 21 & 15 & 20 & 21 & 12 & 5 & 5 & 24 & 16 & 8 & 6 \\
\hline $\mathrm{Cl2}$ & Ceiling @ center, N-S, lower & 75 & 108 & 70 & 151 & 171 & 119 & 252 & 277 & 226 & 315 & 477 & 534 \\
\hline $\mathrm{C} 13$ & Floor, N-S, upper & 20 & 21 & 6 & 63 & 69 & 9 & 21 & 13 & 8 & 19 & 30 & 27 \\
\hline C14 & $\mathrm{N}$ wall, center, $\mathrm{E}-\mathrm{W}$, inner & 38 & 35 & 31 & 39 & 35 & 35 & 34 & 48 & 66 & 29 & 31 & 29 \\
\hline C15 & $\mathrm{N}$ wall, center, E-W, outer & 15 & 21 & 13 & 23 & 26 & 24 & 43 & 74 & 73 & 34 & 29 & 45 \\
\hline S1 & Bullnose door, N-S & 15 & 13 & 83 & 21 & 22 & 156 & 51 & 31 & 457 & 396 & 112 & 74 \\
\hline S2 & Bullnose, E-W, outer mat & 6 & 16 & 58 & 23 & 22 & 100 & 44 & 35 & 138 & 137 & 25 & 29 \\
\hline S3 & Bullnose, N-S, outer mat & 0 & 0 & 0 & 0 & 0 & 0 & 0 & $\mathbf{0}$ & 0 & 0 & 0 & 0 \\
\hline$S 4$ & North wall @W corner, outer mat & 14 & 14 & 11 & 19 & 18 & 23 & 23 & 38 & 35 & 31 & 41 & 42 \\
\hline S5 & North wall @W corner, inner mat & 0 & $\mathbf{0}$ & $\mathbf{0}$ & 0 & 0 & 0 & 0 & $\mathbf{0}$ & o & 0 & 0 & 0 \\
\hline S6 & Door, N-S & 135 & 90 & 146 & $\mathbf{0}$ & 0 & 0 & 121 & 120 & 118 & 160 & 165 & 182 \\
\hline S7 & Door trim, S corner, outer & 18 & 12 & 20 & 17 & 17 & 22 & 34 & 43 & 24 & 26 & 56 & 59 \\
\hline 58 & Floor, N-S, Iower & 12 & 0 & 0 & 0 & 0 & 0 & 0 & 0 & $\mathbf{0}$ & 0 & 0 & 0 \\
\hline 59 & N wall, Zone I shot elev., vert.; inner & 0 & 0 & 0 & 0 & 0 & 0 & 0 & 0 & $\mathbf{0}$ & 0 & 0 & 0 \\
\hline S10 & $\mathrm{N}$ wall, center, vertical, outer & 38 & $\mathbf{0}$ & 0 & 0 & 0 & 0 & 79 & 62 & 88 & 94 & 169 & 80 \\
\hline $\mathbf{S 1 1}$ & $\mathrm{N}$ wall, center, vertical, inner & 30 & 40 & 24 & 39 & 42 & 37 & 86 & 81 & 67 & 0 & 25 & 25 \\
\hline $\mathrm{S} 12$ & $\mathrm{~N}$ wall, top, vertical, inner & 25 & 0 & 0 & 0 & 0 & $\mathbf{0}$ & 0 & 0 & 0 & 0 & 0 & 0 \\
\hline S13 & Ceiling @N wall, $N-S$, inner & 50 & 55 & 39 & 57 & 59 & 45 & 72 & 10 & 82 & 41 & 164 & 7 \\
\hline S14 & Ceiling@ center, N-S, lower & 41 & 0 & 0 & 0 & 0 & $\mathbf{0}$ & 141 & 157 & 106 & 136 & 216 & 236 \\
\hline S15 & Ceiling $@$ center, $N-S$, upper & 20 & 22 & 22 & $\mathbf{0}$ & 0 & $\mathbf{0}$ & 4 & 28 & 0 & 0 & 32 & 53 \\
\hline S16 & Ceiling@ center stirrup & 10 & 16 & 7 & 23 & 25 & 11 & 0 & $\mathbf{0}$ & 0 & 35 & 60. & 68 \\
\hline S17 & Ceiling (NE comer stirrup & 7 & 176 & 1824 & 11 & $\mathbf{0}$ & $\mathbf{0}$ & $\mathbf{0}$ & 0 & 0 & 0 & 13 & 7 \\
\hline $\mathbf{S 1 8}$ & Stirrup, $N$ wall top @ ceiling & 5 & 5 & 6 & 14 & 79 & 11 & 12 & 13 & 13 & 12 & 15 & 17 \\
\hline $\mathbf{S 1 9}$ & Stirrup, $N$ wall center & 0 & 7 & 6 & 14 & 14 & 10 & 36 & 31 & 11 & 12 & 37 & 38 \\
\hline $\mathbf{S 2 0}$ & Stirrup, N wall @ Zone 1 elevation & 8 & 0 & 7 & 23 & 22 & 13 & 40 & 34 & 24 & 25 & 47 & 46 \\
\hline S21 & N wall, Zone 1 shot elev., vert., outer & 15 & 20 & 11 & 31 & 31 & 18 & 50 & 59 & 20 & 33 & 37 & 34 \\
\hline $\mathbf{S 2 2}$ & Floor, upper, E-W & $\mathbf{0}$ & 0 & $\mathbf{0}$ & 0 & 0 & 0 & 0 & $\mathbf{0}$ & 0 & $\mathbf{0}$ & $\mathbf{0}$ & 0 \\
\hline $\mathbf{S 2 3}$ & Stirrup, floor & 175 & 135 & $\mathbf{0}$ & 0 & 392 & 0 & 65 & 61 & $\mathbf{0}$ & 22 & 81 & 67 \\
\hline S24 & Floor, lower, E-W & 10 & 13 & 10 & 19 & 19 & 14 & 12 & 12 & 27 & 0 & 0 & $\mathbf{0}$ \\
\hline $\mathbf{S 2 5}$ & Ceiling haunch @ center $N$ wall & 25 & 23 & 18 & 25 & 23 & 21 & 33 & 26 & 31 & 25 & 33 & 0 \\
\hline $\mathbf{S} 26$ & Wall haunch@ center NE corner & 0 & 0 & 0 & 0 & 0 & 0 & 75 & 73 & 70 & 33 & 39 & 42 \\
\hline $\mathbf{S} 27$ & Stirrup, top of bullnose & 10 & 11 & 19 & 21 & 23 & 34 & 33 & 32 & 38 & 46 & 48 & 51 \\
\hline S28 & E wall $\odot$ door, vertical, outer & 0 & 0 & $\mathbf{0}$ & o & 0 & 0 & 0 & 0 & 0 & 0 & 0 & 0 \\
\hline $\mathbf{S 2 9}$ & Shrapnel plate anchor, $N-S$ & 35 & 185 & 100 & 238 & 272 & 128 & 327 & 300 & $\mathbf{0}$ & 0 & 0 & 0 \\
\hline S30 & Noise gauge (ceiling @ center $\mathbf{N}$ wail) & 5 & 0 & 0 & 0 & 0 & 0 & 17 & 20 & 23 & 55 & 0 & 0 \\
\hline $\mathbf{S 3 1}$ & Anvil bolt, vertical & 0 & 248 & 0 & 0 & 0 & 0 & 334 & 590 & 440 & 0 & 0 & 0 \\
\hline
\end{tabular}


Table A3. Maximum tensile stresses (psi).

\begin{tabular}{|c|c|c|c|c|c|c|c|c|c|c|c|c|c|}
\hline \multicolumn{2}{|c|}{$\begin{array}{l}\text { Test No.: } \\
\text { Test series (QSCT): } \\
\text { C4 explosive weight (lb): } \\
\text { \% of full-scale charge (zone): } \\
\text { Test date (1994): } \\
\text { Gauge }\end{array}$} & $\begin{array}{c}1 \\
2 \\
0.52 \\
25(1) \\
3 / 18\end{array}$ & $\begin{array}{c}2 \\
3 \\
0.52 \\
25(1) \\
4 / 5\end{array}$ & $\begin{array}{c}3 \\
1 \\
0.3 \\
25(4) \\
4 / 5\end{array}$ & $\begin{array}{c}4 \\
5 \\
1.03 \\
50(1) \\
4 / 12\end{array}$ & $\begin{array}{c}5 \\
6 \\
1.03 \\
50(1) \\
4 / 12\end{array}$ & $\begin{array}{c}6 \\
4 \\
0.6 \\
50(4) \\
4 / 12\end{array}$ & $\begin{array}{c}7 \\
8 \\
2.07 \\
100(1) \\
4 / 27\end{array}$ & $\begin{array}{c}8 \\
9 \\
2.07 \\
100(1) \\
4 / 27\end{array}$ & $\begin{array}{c}9 \\
7 \\
1.21 \\
100(4) \\
4 / 27\end{array}$ & $\begin{array}{c}14 \\
10 \\
1.51 \\
125(4) \\
6 / 7\end{array}$ & $\begin{array}{c}15 \\
11 \\
2.58 \\
125(1) \\
6 / 7\end{array}$ & $\begin{array}{c}16 \\
11 \\
2.58 \\
125(1) \\
6 / 8\end{array}$ \\
\hline $\mathrm{Cl}$ & Bullnose, EW, outer & 23 & 23 & 75 & 80 & 51 & 94 & 37 & 23 & 112 & 154 & $\mathbf{2 3}$ & 28 \\
\hline $\mathrm{C} 2$ & Bullnose, & 28 & 28 & 51 & 94 & 112 & 80 & 70 & 66 & 131 & 140 & 75 & 75 \\
\hline C3 & Bullinose, NS, inner & 35 & 37 & 70 & 211 & 201 & 140 & 103 & 94 & 187 & 145 & 98 & 80 \\
\hline $\mathrm{C} 4$ & Floor bottom, NS & 0 & 126 & 56 & 646 & 604 & 103 & 243 & 220 & 89 & 197 & 281 & 234 \\
\hline C5 & Floor top, NS & 421 & 314 & 51 & 908 & 548 & 84 & 112 & 145 & 51 & 150 & 108 & 126 \\
\hline C6 & Door frame, S corner, outer & 0 & 229 & 150 & 304 & 304 & 295 & 449 & 482 & 824 & 515 & 814 & 576 \\
\hline C7 & $\mathrm{N}$ wall, center, vertical, outer & 276 & 314 & 168 & 374 & 384 & 281 & 861 & 800 & 566 & 679 & 562 & 880 \\
\hline $\mathrm{C} 8$ & $\mathrm{~N}$ wall, center, vertical, inner & 117 & 136 & 98 & 154 & 154 & 183 & 257 & 285 & 608 & 351 & 98 & 412 \\
\hline $\mathrm{C} 9$ & $\mathrm{~N}$ wall, top, vertical, outer & 94 & 70 & 42 & 75 & 89 & 80 & 61 & 42 & 183 & 117 & 75 & 66 \\
\hline $\mathrm{C} 10$ & Ceiling $\otimes N$ wall, NS, outer & 37 & 61 & 28 & 56 & 66 & 33 & 56 & 42 & 192 & 89 & 75 & 84 \\
\hline $\mathrm{C} 11$ & Ceiling @ center, NS, upper & 271 & 318 & 178 & 459 & 473 & 229 & 693 & 669 & 356 & 332 & 445 & 473 \\
\hline $\mathrm{C} 12$ & Ceiling $@$ center, NS, lower & 140 & 150 & 234 & 168 & 168 & 431 & 201 & 201 & 393 & 183 & 613 & 665 \\
\hline $\mathrm{C} 13$ & Floor, NS, upper & 211 & 94 & 23 & 566 & 398 & 47 & 61 & 23 & 33 & 56 & 75 & 61 \\
\hline C14 & $\mathrm{N}$ wall, center, $\mathrm{EW}$, inner & 271 & 309 & 168 & 365 & 370 & 257 & 627 & 730 & 482 & 220 & 323 & 346 \\
\hline $\mathrm{C} 15$ & $\mathrm{~N}$ wall, center, EW, outer & 70 & 89 & 66 & 103 & 108 & 131 & 183 & 393 & 402 & 229 & 243 & 271 \\
\hline S1 & Bullnose door, NS & 94 & 75 & 524 & 131 & 178 & 964 & 239 & 267 & 1320 & 1512 & 412 & 253 \\
\hline S2 & Bullno: & 47 & 66 & 192 & 103 & 112 & 271 & 187 & 145 & 417 & 402 & 183 & 117 \\
\hline S3 & Bullnose, $\mathbf{N}$ & 0 & 0 & 0 & 0 & 0 & $\mathbf{0}$ & 0 & $\mathbf{0}$ & 0 & $\mathbf{0}$ & $\mathbf{0}$ & 0 \\
\hline S4 & ner, outer mat & 103 & 122 & 80 & 178 & 159 & 173 & 267 & 295 & 243 & 225 & 337 & 384 \\
\hline S5 & North & 0 & 0 & 0 & 0 & 0 & $\mathbf{0}$ & 0 & 0 & 0 & 0 & 0 & 0 \\
\hline S6 & Door, NS & 632 & 608 & 716 & $\mathbf{0}$ & 0 & 0 & 1689 & 1498 & 987 & 1601 & 2017 & 2012 \\
\hline S7 & Door trim, $S$ corner, outer & 178 & 178 & 122 & 295 & 285 & 295 & 594 & 702 & 800 & 1058 & 206 & 1011 \\
\hline 58 & Floor, & 164 & 0 & $\mathbf{0}$ & o & 0 & 0 & $\mathbf{0}$ & $\mathbf{0}$ & 0 & $\mathbf{0}$ & 0 & 0 \\
\hline S9 & shot elev., vert., inner & 0 & $\mathbf{0}$ & 0 & 0 & 0 & $\mathbf{0}$ & 0 & 0 & 0 & 0 & 0 & 0 \\
\hline S10 & uter & 304 & 0 & 0 & 0 & 0 & 0 & 1460 & 1544 & 1282 & 1680 & 2069 & 2555 \\
\hline S11 & $\mathrm{N}$ wal & 94 & 122 & 84 & 136 & 150 & 173 & 248 & 290 & 276 & 0 & 183 & 183 \\
\hline $\mathrm{S} 12$ & $\mathrm{~N}$ wal & 211 & 0 & 0 & 0 & 0 & 0 & 0 & 0 & 0 & 0 & 0 & 0 \\
\hline $\mathrm{S} 13$ & Ceilin & 421 & 473 & 346 & 683 & 693 & 548 & 1572 & 1718 & 1053 & 1245 & 1353 & 1694 \\
\hline S14 & lower & 140 & 0 & 0 & 0 & o & 0 & 51 & 56 & 215 & 168 & 192 & 248 \\
\hline S15 & upper & 328 & 351 & 351 & $\mathbf{0}$ & 0 & $\mathbf{0}$ & 1020 & 1329 & 0 & o & 1643 & 1605 \\
\hline S16 & Ceiling & 9 & 14 & 14 & 19 & 19 & 19 & 0 & 0 & 0 & 42 & 33 & 28 \\
\hline S17 & corner stirrup & 70 & 5026 & 4395 & 164 & 94 & 94 & $\mathbf{0}$ & 0 & 0 & 0 & 168 & 206 \\
\hline S18 & 9 ceiling & 14 & 37 & 23 & 47 & 94 & 47 & 75 & 103 & 37 & 33 & 84 & 108 \\
\hline S19 & Stirru & 0 & 14 & 19 & 28 & 28 & 19 & 33 & 56 & 42 & 61 & 84 & 89 \\
\hline $\mathbf{S 2 0}$ & & 33 & 0 & 19 & 42 & 37 & 28 & 66 & 61 & 51 & 61 & 47 & 51 \\
\hline S21 & $\mathrm{N}$ wal & 140 & 150 & 98 & 215 & 225 & 145 & 468 & 473 & 332 & 463 & 552 & 693 \\
\hline $\mathrm{S} 22$ & apper, EW & o & $\mathbf{0}$ & 0 & $\mathbf{0}$ & o & $\mathbf{0}$ & 0 & 0 & 0 & 0 & 0 & 0 \\
\hline $\mathbf{S} 23$ & & 187 & 154 & 0 & $\mathbf{0}$ & 473 & 0 & 108 & 103 & 0 & 33 & 14 & 14 \\
\hline S24 & Floo & 140 & 94 & 89 & 154 & 173 & 117 & 206 & 197 & 197 & 0 & 0 & 0 \\
\hline $\mathbf{S 2 5}$ & Ceilin & 187 & 187 & 154 & 332 & 304 & 234 & 468 & 463 & 356 & 417 & 496 & 0 \\
\hline $\mathrm{S} 26$ & Wall $\mathrm{t}$ & 0 & 0 & 0 & 0 & 0 & 0 & 613 & 758 & 585 & 548 & 791 & 683 \\
\hline $\mathbf{S} 27$ & Stirrux & 33 & 42 & 42 & 84 & 66 & 70 & 47 & 47 & 108 & 131 & 98 & 103 \\
\hline $\mathbf{S} 28$ & (8) door, vertical, outer & 0 & 0 & 0 & 0 & 0 & $\mathbf{0}$ & 0 & $\mathbf{0}$ & 0 & 0 & 0 & 0 \\
\hline S29 & Shrap & 1053 & 1348 & 651 & 2256 & 2270 & 1418 & 2874 & 2340 & 0 & 0 & 0 & 0 \\
\hline $\mathbf{s 3 0}$ & Noise gauge (ceiling @ center $\mathrm{N}$ wall) & 23 & 0 & 0 & 0 & 0 & 0 & 80 & 168 & 98 & 257 & 0 & 0 \\
\hline S31 & Anvil bolt, vertical & $\mathbf{0}$ & 5527 & 0 & 0 & 0 & 0 & 33,396 & 33,411 & 34,169 & 0 & 0 & 0 \\
\hline
\end{tabular}


Table A4. Maximum compressive stresses (psi).

\begin{tabular}{|c|c|c|c|c|c|c|c|c|c|c|c|c|c|}
\hline \multicolumn{2}{|c|}{$\begin{array}{l}\text { Test No.: } \\
\text { Test series (QSCT): } \\
\text { C4 explosive weight (lb): } \\
\text { \% of full-scale charge (zone): } \\
\text { Test date (1994): } \\
\text { Gauge }\end{array}$} & $\begin{array}{c}1 \\
2 \\
0.52 \\
25(1) \\
3 / 18\end{array}$ & $\begin{array}{c}2 \\
3 \\
0.52 \\
25(1) \\
4 / 5\end{array}$ & $\begin{array}{c}3 \\
1 \\
0.3 \\
25(4) \\
4 / 5\end{array}$ & $\begin{array}{c}4 \\
5 \\
1.03 \\
50(1) \\
4 / 12\end{array}$ & $\begin{array}{c}5 \\
6 \\
1.03 \\
50(1) \\
4 / 12\end{array}$ & $\begin{array}{c}6 \\
4 \\
0.6 \\
50(4) \\
4 / 12\end{array}$ & $\begin{array}{c}7 \\
8 \\
2.07 \\
100(1) \\
4 / 27\end{array}$ & $\begin{array}{c}8 \\
9 \\
2.07 \\
100(1) \\
4 / 27\end{array}$ & $\begin{array}{c}9 \\
7 \\
1.21 \\
100(4) \\
4 / 27\end{array}$ & $\begin{array}{c}14 \\
10 \\
1.51 \\
125(4) \\
6 / 7\end{array}$ & $\begin{array}{c}15 \\
11 \\
2.58 \\
125(1) \\
6 / 7\end{array}$ & $\begin{array}{c}16 \\
11 \\
2.58 \\
125(1) \\
6 / 8\end{array}$ \\
\hline C1 & Bullnose, EW, outer & 14 & 42 & 168 & 206 & 201 & 290 & 126 & 103 & 435 & 351 & 84 & 84 \\
\hline C2 & Bullnose, EW, inner & 28 & 37 & 89 & 229 & 192 & 201 & 108 & 108 & 234 & 257 & 192 & 192 \\
\hline C3 & Bullnose, NS, inner & 28 & 33 & 61 & 150 & 154 & 84 & 98 & 112 & 150 & 94 & 84 & 94 \\
\hline $\mathrm{C}_{4}$ & Floor bottom, NS & 0 & 47 & 51 & 164 & 187 & 70 & 66 & 75 & 42 & 56 & 19 & 37 \\
\hline C5 & Floor top, NS & 117 & 183 & 61 & 510 & 281 & 103 & 168 & 164 & 70 & 117 & 75 & 187 \\
\hline C6 & Door frame, $\mathrm{S}$ corner, outer & 0 & 126 & 94 & 98 & 117 & 159 & 187 & 239 & 234 & 117 & 328 & 398 \\
\hline $\mathrm{C7}$ & N wall, center, vertical, outer & 173 & 159 & 140 & 187 & 178 & 164 & 126 & 164 & 337 & 220 & 23 & 285 \\
\hline $\mathrm{C} 8$ & $\mathrm{~N}$ wall, center, vertical, inner & 140 & 164 & 98 & 173 & 192 & 168 & 360 & 323 & 557 & 229 & 622 & 346 \\
\hline $\mathrm{C} 9$ & $\mathrm{~N}$ wall, top, vertical, outer & 150 & 164 & 112 & 267 & 271 & 220 & 421 & 435 & 665 & 360 & 482 & 515 \\
\hline $\mathrm{C} 10$ & Ceiling $@ N$ wall, NS, outer & 66 & 89 & 51 & 117 & 112 & 84 & 145 & 164 & 257 & 131 & 206 & 267 \\
\hline C11 & Ceiling @ center, NS, upper & 84 & 98 & 70 & 94 & 98 & 56 & 23 & 23 & 112 & 75 & 37 & 28 \\
\hline $\mathrm{C} 12$ & Ceiling @ center, NS, Iower & 351 & 505 & 328 & 707 & 800 & 557 & 1179 & 1296 & 1058 & 1474 & 2232 & 2499 \\
\hline C13 & Floor, NS, upper & 94 & 98 & 28 & 295 & 323 & 42 & 98 & 61 & 37 & 89 & 140 & 126 \\
\hline $\mathrm{C} 14$ & $\mathrm{~N}$ wall, center, $\mathrm{EW}$, inner & 178 & 164 & 145 & 183 & 164 & 164 & 159 & 225 & 309 & 136 & 145 & 136 \\
\hline $\mathrm{C} 15$ & N wall, center, EW, outer & 70 & 98 & 61 & 108 & 122 & 112 & 201 & 346 & 342 & 159 & 136 & 211 \\
\hline S1 & Bullnose door, NS & 70 & 61 & 388 & 98 & 103 & 730 & 239 & 145 & 2139 & 1853 & 524 & 346 \\
\hline S2 & Bullnose, EW, outer mat & 28 & 75 & 271 & 108 & 103 & 468 & 206 & 164 & 646 & 641 & 117 & 136 \\
\hline S3 & Bullnose, NS, outer mat & 0 & $\mathbf{0}$ & 0 & 0 & 0 & 0 & $\mathbf{0}$ & 0 & 0 & 0 & $\mathbf{0}$ & 0 \\
\hline S4 & North wall $1 \mathrm{~W}$ corner, outer mat & 66 & 66 & 51 & 89 & 84 & 108 & 108 & 178 & 164 & 145. & 192 & 197 \\
\hline S5 & North wall $1 W$ corner, inner mat & 0 & $\mathbf{0}$ & $\mathbf{0}$ & 0 & 0 & $\mathbf{0}$ & 0 & 0 & 0 & 0 & 0 & 0 \\
\hline S6 & Door, NS & 632 & 421 & 683 & 0 & $\mathbf{0}$ & 0 & 566 & 562 & 552 & 749 & 772 & 852 \\
\hline S7 & Door trim, S corner, outer & 84 & 56 & 94 & 80 & 80 & 103 & 159 & 201 & 112 & 122 & 262 & 276 \\
\hline S8 & Floor, NS, lower & 56 & $\mathbf{0}$ & 0 & 0 & 0 & 0 & 0 & 0 & 0 & $\mathbf{0}$ & 0 & 0 \\
\hline S9 & N wall, Zone 1 shot elev., vert., inner & 0 & 0 & 0 & 0 & 0 & 0 & 0 & 0 & 0 & 0 & 0 & 0 \\
\hline S10 & $\mathrm{N}$ wall, center, vertical, outer & 178 & $\mathbf{0}$ & $\mathbf{0}$ & 0 & 0 & 0 & 370 & 290 & 412 & 440 & 791 & 374 \\
\hline S11 & $\mathrm{N}$ wall, center, vertical, inner & 140 & 187 & 112 & 183 & 197 & 173 & 402 & 379 & 314 & 0 & 117 & 117 \\
\hline S12 & $\mathrm{N}$ wall, top, vert & 117 & 0 & 0 & o & $\mathbf{0}$ & $\mathbf{0}$ & 0 & $\mathbf{0}$ & $\mathbf{0}$ & 0 & 0 & 0 \\
\hline $\mathrm{S} 13$ & Ceiling $@ N$ wall, NS, inner & 234 & 257 & 183 & 267 & 276 & 211 & 337 & 47 & 384 & 192 & 768 & 33 \\
\hline S14 & Ceiling @ center, NS, lower & 192 & 0 & 0 & 0 & 0 & 0 & 660 & 735 & 496 & 636 & 1,011 & 1,104 \\
\hline S15 & Ceiling @ center, NS, upper & 94 & 103 & 103 & 0 & $\mathbf{0}$ & 0 . & 19 & 131 & $\mathbf{0}$ & 0 & 150 & 248 \\
\hline S16 & Ceiling @ center stirrup & 47 & 75 & 33 & 108 & 117 & 51 & 0 & 0 & 0 & 164 & 281 & 318 \\
\hline S17 & Ceiling $\odot N E$ corner stirrup & 33 & 824 & 8,536 & 51 & 0 & $\mathbf{0}$ & 0 & 0 & 0 & 0 & 61 & 33 \\
\hline S18 & Stirrup, $\mathrm{N}$ wall top 1 ceiling & 23 & 23 & 28 & 66 & 370 & 51 & 56 & 61 & 61 & 56 & 70 & 80 \\
\hline S19 & Stirrup, $\mathrm{N}$ wall center & 0 & 33 & 28 & 66 & 66 & 47 & 168 & 145 & 51 & 56 & 173 & 178 \\
\hline S20 & Stirrup, N wall @ Zone 1 elevation & 37 & 0 & 33 & 108 & 103 & 61 & 187 & 159 & 112 & 117 & 220 & 215 \\
\hline S21 & $\mathrm{N}$ wall, Zone 1 shot elev., vert., outer & 70 & 94 & 51 & 145 & 145 & 84 & 234 & 276 & 94 & 154 & 173 & 159 \\
\hline $\mathbf{S 2 2}$ & Floor, upper, EW & 0 & 0 & 0 & 0 & 0 & 0 & 0 & 0 & 0 & 0 & 0 & 0 \\
\hline $\mathbf{S 2 3}$ & Stirrup, floor & 819 & 632 & 0 & 0 & 1,835 & $\mathbf{0}$ & 304 & 285 & 0 & 103 & 379 & 314 \\
\hline $\mathbf{S 2 4}$ & Floor, lower, EW & 47 & 61 & 47 & 89 & 89 & 66 & 56 & 56 & 126 & 0 & 0 & 0 \\
\hline $\mathbf{S 2 5}$ & Ceiling haunch $\odot$ center $\mathrm{N}$ wall & 117 & 108 & 84 & 117 & 108 & 98 & 154 & 122 & 145 & 117 & 154 & 0 \\
\hline S26 & NE corner & 0 & 0 & 0 & $\mathbf{0}$ & 0 & $\mathbf{0}$ & 351 & 342 & 328 & 154 & 183 & 197 \\
\hline S27 & Stirrup, top of bulinose & 47 & 51 & 89 & 98 & 108 & 159 & 154 & 150 & 178 & 215 & 225 & 239 \\
\hline S28 & E wall @ door, vertical, outer & 0 & 0 & 0 & $\mathbf{0}$ & 0 & 0 & 0 & 0 & 0 & 0 & 0 & 0 \\
\hline S29 & Shrapnel plate anchor, NS & 164 & 866 & 468 & 1114 & 1273 & 599 & 1530 & 1404 & 0 & 0 & 0 & 0 \\
\hline $\mathbf{S 3 0}$ & Noise gauge (ceiling center $\mathbf{N}$ wall) & 23 & $\mathbf{0}$ & $\mathbf{0}$ & 0 & 0 & 0 & 80 & 94 & 108 & 257 & 0 & 0 \\
\hline $\mathbf{S 3 1}$ & Anvil bolt, vertical & 0 & 1161 & $\mathbf{0}$ & 0 & $\mathbf{0}$ & 0 & 1563 & 2761 & 2059 & $\mathbf{0}$ & 0 & 0 \\
\hline
\end{tabular}


Table A5. Maximum tensile safety factors (SF) to yield.

\begin{tabular}{|c|c|c|c|c|c|c|c|c|c|c|c|c|c|}
\hline $\begin{array}{l}\text { Test No.: } \\
\text { Test serie } \\
\text { C4 explos } \\
\% \text { of full- } \\
\text { Test date } \\
\text { Gauge }\end{array}$ & $\begin{array}{l}\text { (QSCT): } \\
\text { ive weight (lb): } \\
\text { scale charge (zone): } \\
\text { (1994): }\end{array}$ & $\begin{array}{c}1 \\
2 \\
0.52 \\
25(1) \\
3 / 18\end{array}$ & $\begin{array}{c}2 \\
3 \\
0.52 \\
25(1) \\
4 / 5\end{array}$ & $\begin{array}{c}3 \\
1 \\
0.3 \\
25(4) \\
4 / 5\end{array}$ & $\begin{array}{c}4 \\
5 \\
1.03 \\
50(1) \\
4 / 12\end{array}$ & $\begin{array}{c}5 \\
6 \\
1.03 \\
50(1) \\
4 / 12\end{array}$ & $\begin{array}{c}6 \\
4 \\
0.6 \\
50(4) \\
4 / 12\end{array}$ & $\begin{array}{c}7 \\
8 \\
2.07 \\
100(1) \\
4 / 27\end{array}$ & $\begin{array}{c}8 \\
9 \\
2.07 \\
100(1) \\
4 / 27\end{array}$ & $\begin{array}{c}9 \\
7 \\
1.21 \\
100(4) \\
4 / 27\end{array}$ & $\begin{array}{c}14 \\
10 \\
1.51 \\
125(4) \\
6 / 7\end{array}$ & $\begin{array}{c}15 \\
11 \\
2.58 \\
125(1) \\
6 / 7\end{array}$ & $\begin{array}{l}16 \\
11 \\
2.58 \\
125(1) \\
6 / 8\end{array}$ \\
\hline $\mathrm{Cl}$ & Bullnose, EW, outer & 25.00 & 25.00 & 7.81 & 7.35 & 11.36 & 6.25 & 15.63 & 25.00 & 5.21 & 3.79 & 25.00 & 20.83 \\
\hline $\mathrm{C} 2$ & Bullnose, EW, inner & 20.83 & 20.83 & 11.36 & 6.25 & 5.21 & 7.35 & 8.33 & 8.93 & 4.46 & 4.17 & 7.81 & 7.81 \\
\hline $\mathrm{C} 3$ & Bullnose, NS, inner & 16.67 & 15.63 & 8.33 & 2.78 & 2.91 & 4.17 & 5.68 & 6.25 & 3.13 & 4.03 & 5.95 & 7.35 \\
\hline $\mathrm{C4}$ & Floor bottom, NS & - & 4.63 & 10.42 & 0.91 & 0.97 & 5.68 & 2.40 & 2.66 & 6.58 & 2.98 & 2.08 & 2.50 \\
\hline C5 & Floor top, NS & 1.39 & 1.87 & 11.36 & 0.64 & 1.07 & 6.94 & 5.21 & 4.03 & 11.36 & 3.91 & 5.43 & 4.63 \\
\hline C6 & Door frame, $\mathrm{S}$ corner, outer & - & 2.55 & 3.91 & 1.92 & 1.92 & 1.98 & 1.30 & 1.21 & 0.71 & 1.14 & 0.72 & 1.02 \\
\hline $\mathrm{C} 7$ & N wall, center, vertical, outer & 2.12 & 1.87 & 3.47 & 1.56 & 1.52 & 2.08 & 0.68 & 0.73 & 1.03 & 0.86 & 1.04 & 0.66 \\
\hline $\mathrm{C} 8$ & $\mathrm{~N}$ wall, center, vertical, inner & 5.00 & 4.31 & 5.95 & 3.79 & 3.79 & 3.21 & 2.27 & 2.05 & 0.96 & 1.67 & 5.95 & 1.42 \\
\hline $\mathrm{Cg}$ & $\mathrm{N}$ wall, top, ver & 6.25 & 8.33 & 13.89 & 7.81 & 6.58 & 7.35 & 9.62 & 13.89 & 3.21 & 5.00 & 7.81 & 8.93 \\
\hline $\mathrm{C} 10$ & Ceiling@N wall, NS, outer & 15.63 & 9.62 & 20.83 & 10.42 & 8.93 & 17.86 & 10.42 & 13.89 & 3.05 & 6.58 & 7.81 & 6.94 \\
\hline C11 & Ceiling@ center, NS, upper & 2.16 & 1.84 & 3.29 & 1.28 & 1.24 & 2.55 & 0.84 & 0.87 & 1.64 & 1.76 & 1.32 & 1.24 \\
\hline $\mathrm{C} 12$ & Ceiling @ center, NS, lower & 4.17 & 3.91 & 2.50 & 3.47 & 3.47 & 1.36 & 2.91 & 2.91 & 1.49 & 3.21 & 0.95 & 0.88 \\
\hline $\mathrm{C} 13$ & Floor, NS, upper & 2.78 & 6.25 & 25.00 & .1 .03 & 1.47 & 12.50 & 9.62 & 25.00 & 17.86 & 10.42 & 7.81 & 9.62 \\
\hline $\mathrm{C} 14$ & $\mathrm{~N}$ wall, center, EW, inner & 2.16 & 1.89 & 3.47 & 1.60 & 1.58 & 2.27 & 0.93 & 0.80 & 1.21 & 2.66 & 1.81 & 1.69 \\
\hline $\mathrm{C} 15$ & $\mathrm{~N}$ wall, center, EW, outer & 8.33 & 6.58 & 8.93 & 5.68 & 5.43 & 4.46 & 3.21 & 1.49 & 1.45 & 2.55 & 2.40 & 2.16 \\
\hline S1 & door, NS & 75.00 & 93.75 & 13.39 & 53.57 & 39.47 & 7.28 & 29.41 & 26.32 & 5.32 & 4.64 & 17.05 & 27.78 \\
\hline S2 & Bullnose, EW, outer mat & 258.62 & 184.73 & 63.08 & 117.55 & 107.76 & 44.59 & 64.66 & 83.43 & 29.06 & 30.07 & 66.31 & 103.45 \\
\hline S3 & Bullnose, NS, outer mat & - & 一 & - & - & - & - & - & - & 一 & - & - & - \\
\hline S4 & North wall @W corner, outer mat & 117.55 & 99.47 & 152.13 & 68.06 & 76.06 & 69.90 & 45.37 & 41.05 & 49.73 & 53.88 & 35.92 & 31.54 \\
\hline S5 & North wall @W corner, inner mat & - & 一 & 一 & 一 & - & - & 一 & - & - & - & 一 & - \\
\hline S6 & Door, NS & 11.11 & 11.54 & 9.80 & - & $一$ & - & 4.16 & 4.69 & 7.11 & 4.39 & 3.48 & 3.49 \\
\hline S7 & Door $\mathrm{tr}$ & 68.06 & 68.06 & 99.47 & 41.05 & 42.40 & 41.05 & 20.36 & 17.24 & 15.12 & 11.44 & 58.78 & 11.97 \\
\hline S8 & Floor, NS, lower & 73.89 & - & 一 & - & 一 & - & 一 & 一 & - & - & 一 & 一 \\
\hline \$9 & N wall, Zone I shot elev., vert., inner & - & - & 一 & 一 & 一 & 一 & 一 & 一 & 一 & 一 & 一 & 一 \\
\hline S10 & $\mathrm{N}$ wall, center, vertical, outer & 39.79 & - & 一 & - & - & - & 8.29 & 7.84 & 9.44 & 7.20 & 5.85 & 4.74 \\
\hline S11 & N wall, center, vertical, inner & 129.31 & 99.47 & 143.68 & 89.18 & 80.82 & 69.90 & 48.80 & 41.71 & 43.83 & 一 & 66.31 & 66.31 \\
\hline $\mathbf{S 1 2}$ & $\mathrm{N}$ wall, top, vertical, inner & 57.47 & - & - & 一 & 一 & 一 & 一 & - & 一 & 一 & 一 & 一 \\
\hline S13 & Ceiling@N wall, $N$ & 28.74 & 25.61 & 34.95 & 17.71 & 17.47 & 22.10 & 7.70 & 7.05 & 11.49 & 9.72 & 8.95 & 7.14 \\
\hline S14 & Ceiling @ cent & 86.21 & 一 & - & - & 一 & - & 235.11 & 215.52 & 56.22 & 71.84 & 63.08 & 48.80 \\
\hline S15 & Ceiling @ center, NS, upper & 36.95 & 34.48 & 34.48 & - & 一 & - & 11.86 & 9.11 & - & - & 7.37 & 7.54 \\
\hline S16 & Ceiling @ center stirrup & 1293.10 & 862.07 & 862.07 & 646.55 & 646.55 & 646.55 & - & - & - & 287.36 & 369.46 & 431.03 \\
\hline S17 & Ceiling @ NE corner stirrup & 172.41 & 2.41 & 2.75 & 73.89 & 129.31 & 129.31 & - & 一 & - & - & 71.84 & 58.78 \\
\hline S18 & Stimup, N wall top @ ceiling & 862.07 & 323.28 & 517.24 & 258.62 & 129.31 & 258.62 & 161.64 & 117.55 & 323.28 & 369.46 & 143.68 & 112.44 \\
\hline S19 & Stirrup, $\mathbf{N}$ wall center & - & 862.07 & 646.55 & 431.03 & 431.03 & 646.55 & 369.46 & 215.52 & 287.36 & 198.94 & 143.68 & 136.12 \\
\hline $\mathbf{S 2 0}$ & Stirrup, N wall @ Zone 1 elevation & 369.46 & - & 646.55 & 287.36 & 323.28 & 431.03 & 184.73 & 198.94 & 235.11 & 198.94 & 258.62 & 235.11 \\
\hline S21 & $\mathrm{N}$ wall, Zone 1 shot elev., vert., outer & 86.21 & 80.82 & 123.15 & 56.22 & 53.88 & 83.43 & 25.86 & 25.61 & 36.43 & 26.12 & 21.92 & 17.47 \\
\hline $\mathbf{S 2 2}$ & Floor, upper, EW & 一 & - & 一 & - & - & 一 & 一 & 一 & 一 & - & 一 & 一 \\
\hline $\mathbf{S 2 3}$ & Stirrup, floor & 64.66 & 78.37 & 一 & - & 25.61 & - & 112.44 & 117.55 & - & 369.46 & 862.07 & 862.07 \\
\hline S24 & Floor, lower, EW & 86.21 & 129.31 & 136.12 & 78.37 & 69.90 & 103.45 & 58.78 & 61.58 & 61.58 & 一 & - & 一 \\
\hline $\mathbf{S 2 5}$ & Ceiling haunch @ center $\mathrm{N}$ wall & 64.66 & 64.66 & 78.37 & 36.43 & 39.79 & 51.72 & 25.86 & 26.12 & 34.03 & 29.06 & 24.40 & - \\
\hline S26 & Wall haunch @ center NE comer & - & 一 & - & 一 & 一 & - & 19.74 & 15.96 & 20.69 & 22.10 & 15.30 & 17.71 \\
\hline S27 & Stirrup, top of bullnose & 369.46 & 287.36 & 287.36 & 143.68 & 184.73 & 172.41 & 258.62 & 258.62 & 112.44 & 92.36 & 123.15 & 117.55 \\
\hline S28 & E wall @ door, vertical, outer & 一 & 一 & - & 一 & 一 & - & 一 & - & - & 一 & - & - \\
\hline $\mathbf{S 2 9}$ & Shrapnel plate anchor, NS & 6.67 & 5.21 & 10.79 & 3.11 & 3.09 & 4.95 & 2.44 & 3.00 & - & - & - & - \\
\hline S30 & Noise gage (ceiling @ center $\mathrm{N}$ wall) & 517.24 & 一 & 一 & - & - & - & 152.13 & 71.84 & 123.15 & 47.02 & - & 一 \\
\hline S31 & Anvil bolt, vertical & - & 1.27 & 一 & 一 & - & - & 0.21 & 0.21 & 0.21 & 一 & 一 & 一 \\
\hline
\end{tabular}

Bold type indicates yielding (SF $<1$ ). 
Table A6. Maximum compressive safety factors (SF) to yield.

\begin{tabular}{|c|c|c|c|c|c|c|c|c|c|c|c|c|c|}
\hline \multicolumn{2}{|c|}{$\begin{array}{l}\text { Test No.: } \\
\text { Test series (QSCT): } \\
\text { C4 explosive weight (lb): } \\
\text { \% of full-scale charge (zone): } \\
\text { Test date (1994): } \\
\text { Gauge }\end{array}$} & $\begin{array}{c}1 \\
2 \\
0.52 \\
25(1) \\
3 / 18\end{array}$ & $\begin{array}{c}2 \\
3 \\
0.52 \\
25(1) \\
4 / 5\end{array}$ & $\begin{array}{c}3 \\
1 \\
0.3 \\
25(4) \\
4 / 5\end{array}$ & $\begin{array}{c}4 \\
5 \\
1.03 \\
50(1) \\
4 / 12\end{array}$ & $\begin{array}{c}5 \\
6 \\
1.03 \\
50(1) \\
4 / 12\end{array}$ & $\begin{array}{c}6 \\
4 \\
0.6 \\
50(4) \\
4 / 12\end{array}$ & $\begin{array}{c}7 \\
8 \\
2.07 \\
100(1) \\
4 / 27\end{array}$ & $\begin{array}{c}8 \\
9 \\
2.07 \\
100(1) \\
4 / 27\end{array}$ & $\begin{array}{c}9 \\
7 \\
1.21 \\
100(4) \\
4 / 27\end{array}$ & $\begin{array}{c}14 \\
10 \\
1.51 \\
125(4) \\
6 / 7\end{array}$ & $\begin{array}{c}15 \\
11 \\
2.58 \\
125(1) \\
6 / 7\end{array}$ & $\begin{array}{l}16 \\
11 \\
2.58 \\
125(1) \\
6 / 8\end{array}$ \\
\hline C1 & Bullnose, EW, outer & 470.1 & 156.7 & 39.2 & 32.1 & 32.8 & 22.7 & 52.2 & 64.1 & 15.2 & 18.8 & 78.3 & 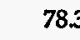 \\
\hline C2 & Bullnose, EW, inner & 235.0 & 176.3 & 74.2 & 28.8 & 34.4 & 32.8 & 61.3 & 61.3 & 28.2 & 25.6 & 34.4 & 34.4 \\
\hline $\mathrm{C} 3$ & Bullnose, NS, inner & 235.0 & 201.5 & 108.5 & 44.1 & 42.7 & 78.3 & 672 & 58.8 & 44.1 & 70.5 & 78.3 & 70. \\
\hline C4 & Floor bottom, NS & - & 141.0 & 128.2 & 40.3 & 35.3 & 94.0 & 100.7 & 88.1 & 156.7 & 117.5 & 352.6 & 176.3 \\
\hline C5 & Floor top, NS & 56.4 & 36.2 & 108.5 & 12.9 & 23.5 & 64.1 & 39.2 & 40.3 & 94.0 & 56.4 & 88.1 & 35.3 \\
\hline C6 & Door frame, $\mathrm{S}$ corner, outer & - & 52.2 & 70.5 & 67.2 & 56.4 & 41.5 & 35.3 & 27.7 & 28.2 & 56.4 & 20.1 & 16.6 \\
\hline $\mathrm{C} 7$ & $\mathrm{~N}$ wall, center, $\mathrm{v}$ & 38.1 & 41.5 & 47.0 & 35.3 & 37.1 & 40.3 & 52.2 & 40.3 & 19.6 & 30.0 & 282.1 & 23.1 \\
\hline C8 & $\mathrm{N}$ wall, center, & 47.0 & 40.3 & 67.2 & 38.1 & 34.4 & 39.2 & 18.3 & 20.4 & 11.9 & 28.8 & 10.6 & 19.1 \\
\hline $\mathrm{Cg}$ & $\mathbf{N}$ wal & 44.1 & 40.3 & 58.8 & 24.7 & 24.3 & 30.0 & 15.7 & 15.2 & 9.9 & 18.3 & 13.7 & 12.8 \\
\hline $\mathrm{C} 10$ & Ceiling @ N wall, NS, outer & 100.7 & 74.2 & 128.2 & 56.4 & 58.8 & 78.3 & 45.5 & 40.3 & 25.6 & 50.4 & 32.1 & 24.7 \\
\hline $\mathrm{C} 11$ & Ceiling $@$ center, NS, upper & 78.3 & 67.2 & 94.0 & 70.5 & 67.2 & 117.5 & 282.1 & 282.1 & 58.8 & 88.1 & 176.3 & 235.0 \\
\hline $\mathrm{C} 12$ & Ceiling $@$ center, 1 & 18.8 & 13.1 & 20.1 & 9.3 & 8.2 & 11.9 & 5.6 & 5.1 & 6.2 & 4.5 & 3.0 & 2. \\
\hline $\mathrm{C} 13$ & Floor, NS, upper & 70.5 & 67.2 & 235.0 & 22.4 & 20.4 & 156.7 & 67.2 & 108.5 & 176.3 & 74.2 & 47.0 & 52. \\
\hline $\mathrm{C} 14$ & $\mathbf{N}$ wall, center, $\mathrm{EW}$, inner & 37.1 & 40.3 & 45.5 & 36.2 & 40.3 & 40.3 & 41.5 & 29.4 & 21.4 & 48.6 & 45.5 & 48.6 \\
\hline $\mathrm{C} 15$ & $\mathrm{~N}$ wall, center, EW, outer & 94.0 & 67.2 & 108.5 & 61.3 & 54.2 & 58.8 & 32.8 & 19.1 & 19.3 & 41.5 & $48: 6$ & 31.3 \\
\hline SI & Bullnose door, NS & 100.0 & 115.4 & 18.1 & 71.4 & 68.2 & 9.6 & 29.4 & 48.4 & 3.3 & 3.8 & 13.4 & 20.3 \\
\hline S2 & Bullnose, EW, outer mat & 431.0 & 161.6 & 44.6 & 112.4 & 117.6 & 25.9 & 58.8 & 73.9 & 18.7 & 18.9 & 103.4 & 89.2 \\
\hline S3 & Bullnos & - & - & $\div$ & - & - & - & - & - & - & - & - & - \\
\hline 54 & North n & 184.7 & 184.7 & 235.1 & 136.1 & 143.7 & 112.4 & 112.4 & 68.1 & 73.9 & 83.4 & 63.1 & 61. \\
\hline S5 & North & - & - & - & - & - & - & - & - & - & - & - & - \\
\hline S6 & Door, & 11.1 & 16.7 & 10.3 & - & - & - & 12.4 & 12.5 & 12.7 & 9.4 & 9.1 & 8.2 \\
\hline S7 & Door & 143.7 & 215.5 & 129.3 & 152.1 & 152.1 & 117.6 & 76.1 & 60.1 & 107.8 & 99.5 & 46.2 & 43.8 \\
\hline 58 & Floor & 215.5 & - & - & - & - & - & - & - & - & - & - & - \\
\hline \$9 & Nwa & - & - & 一 & - & - & - & 一 & - & - & 一 & - & - \\
\hline $\mathbf{S 1 0}$ & N wa & 68.1 & - & - & - & - & - & 32.7 & 41.7 & 29.4 & 27.5 & 15.3 & 32.3 \\
\hline S11 & Nwa & 86.2 & 64.7 & 107.8 & 66.3 & 61.6 & 69.9 & 30.1 & 31.9 & 38.6 & - & 103.4 & 103.4 \\
\hline S12 & $\mathbf{N}$ wal & 103.4 & - & - & - & - & - & - & - & - & - & - & - \\
\hline S13 & Ceiling & 51.7 & 47.0 & 66.3 & 45.4 & 43.8 & 57.5 & 35.9 & 258.6 & 31.5 & 63.1 & 15.8 & 369 \\
\hline S14 & Ceiling & 63.1 & - & - - & - & - & - & 18.3 & 16.5 & 24.4 & 19.0 & 12.0 & 11. \\
\hline $\mathbf{S 1 5}$ & Ceiling & 129.3 & 117.6 & 117.6 & - & - & - & 646.6 & 92.4 & - & - & 80.8 & 48.8 \\
\hline S16 & Ceilin & 258.6 & 161.6 & 369.5 & 112.4 & 103.4 & 235.1 & - & - & - & 73.9 & 43.1 & 38.0 \\
\hline S17 & Ceiling & 369.5 & 14.7 & 1.4 & 235.1 & - & - & - & - & - & - & 198.9 & 369.5 \\
\hline S18 & Stirrup, $N$ wall top @ ceiling & 517.2 & 517.2 & 431.0 & 184.7 & 327 & 235.1 & 215.5 & 198.9 & 198.9 & 215.5 & 1724 & 152.1 \\
\hline S19 & Stirrup, $\mathbf{N}$ wall center & - & 369.5 & 431.0 & 184.7 & 184.7 & 258.6 & 71.8 & 83.4 & 235.1 & 215.5 & 69.9 & 68.1 \\
\hline $\mathbf{S 2 0}$ & Stirrup, $\mathbf{N}$ wall @ Zo & 323.3 & - & 369.5 & 112.4 & 117.6 & 198.9 & 64.7 & 76.1 & 107.8 & 103.4 & 55.0 & 56.2 \\
\hline S21 & $\mathrm{N}$ wal & 172.4 & 129.3 & 235.1 & 83.4 & 83.4 & 143.7 & 51.7 & 43.8 & 129.3 & 78.4 & 69.9 & 76.1 \\
\hline $\mathbf{S 2 2}$ & Floor, & - & - & - & - & - & - & - & - & - & - & - & - \\
\hline $\mathbf{S 2 3}$ & Stirrup & 14.8 & 19.2 & - & - & 6.6 & - & 39.8 & 42.4 & - & 117.6 & 31.9 & 38 \\
\hline S24 & Floor, lower, EW & 258.6 & 198.9 & 258.6 & 136.1 & 136.1 & 184.7 & 215.5 & 215.5 & 95.8 & - & - & - \\
\hline $\mathbf{S} 25$ & Ceiling haunch $@$ center $N$ wall & 103.4 & 112.4 & 143.7 & 103.4 & 112.4 & 123.2 & 78.4 & 99.5 & 83.4 & 103.4 & 78.4 & - \\
\hline S26 & Wall haunch @ center NE corner & - & - & - & - & - & - & 34.5 & 35.4 & 36.9 & 78.4 & 66.3 & 61.6 \\
\hline S27 & Stirrup, top of bullnose & 258.6 & 235.1 & 136.1 & 123.2 & 112.4 & 76.1 & 78.4 & 80.8 & 68.1 & 56.2 & 53.9 & 50.7 \\
\hline S28 & E wall @ door, vertical, outer & - & - & - & - & - & - & - & - & - & - & - & - \\
\hline $\mathbf{S} 29$ & Shrapnel plate anchor, NS & 42.9 & 8.1 & 15.0 & 6.3 & 5.5 & 11.7 & 4.6 & 5.0 & - & - & 一 & - \\
\hline S30 & Noise gauge (ceiling @ center $\mathrm{N}$ wall) & 5172 & - & - & - & - & - & 152.1 & 129.3 & 112.4 & 47.0 & - & - \\
\hline $\mathbf{S 3 1}$ & Anvil bolt, vertical & - & 6.0 & - & - & - & - & 4.5 & 2.5 & 3.4 & - & - & - \\
\hline
\end{tabular}




\section{Appendix B Structural Drawings}

AAA92-106177

(sheets 1-5) 


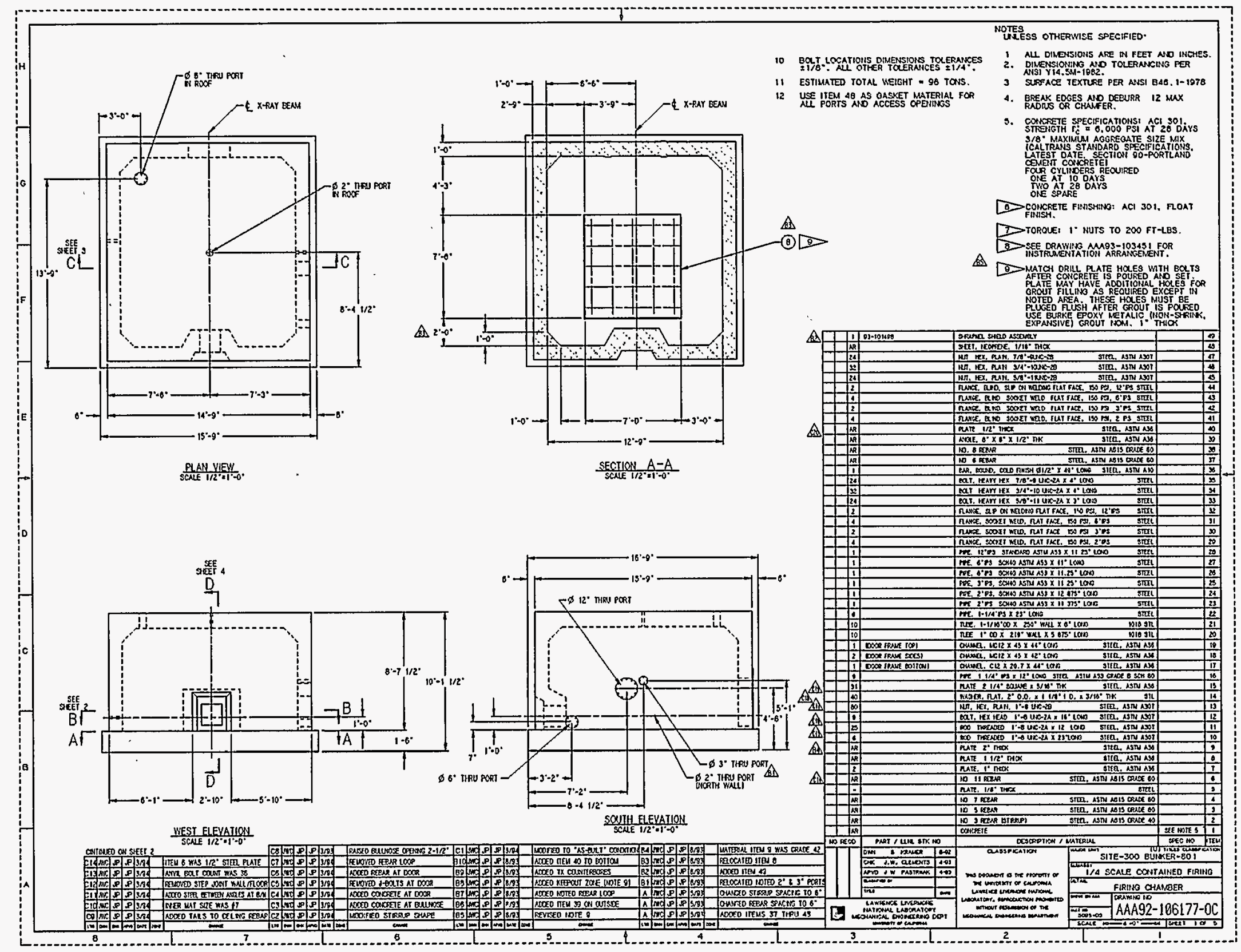




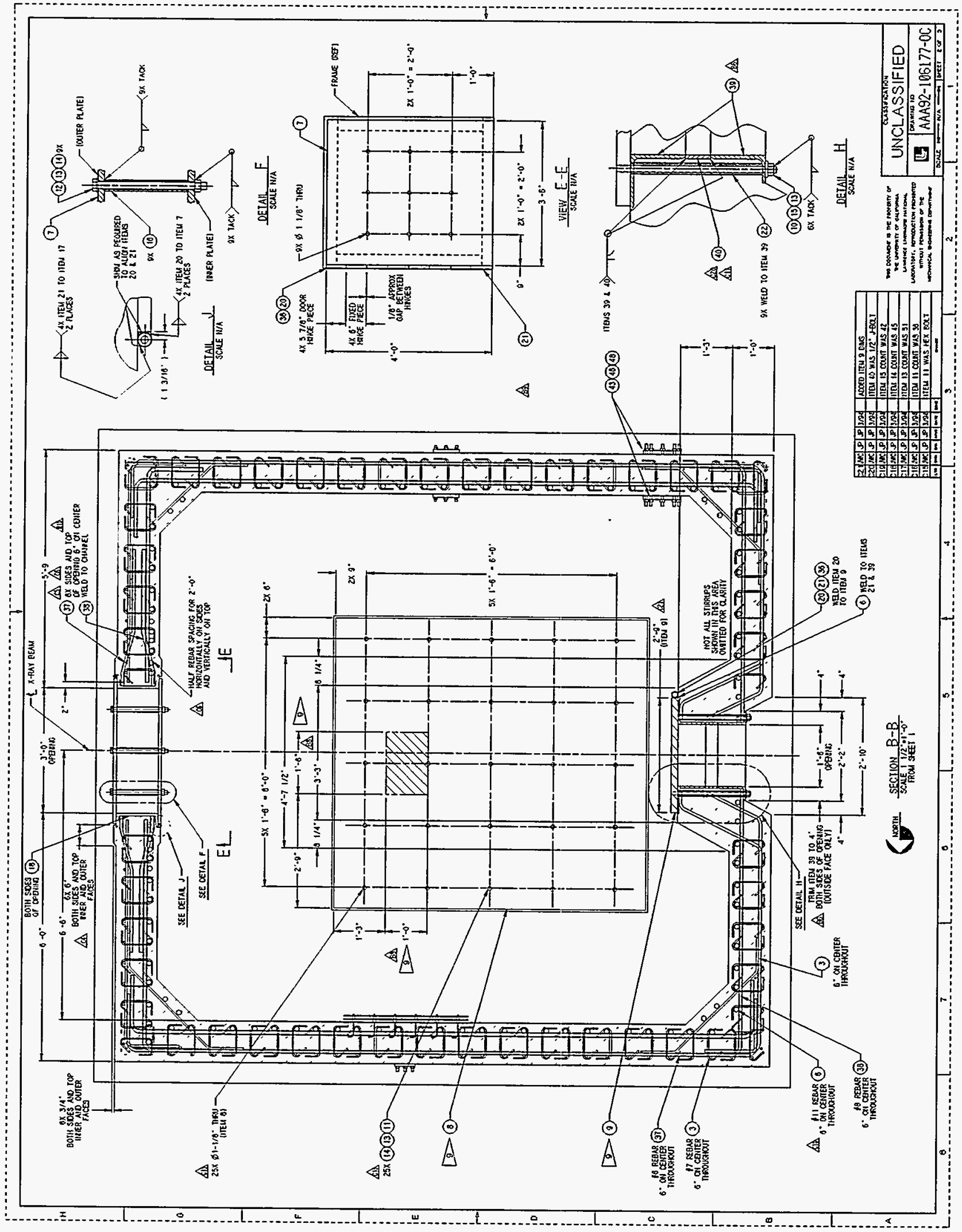




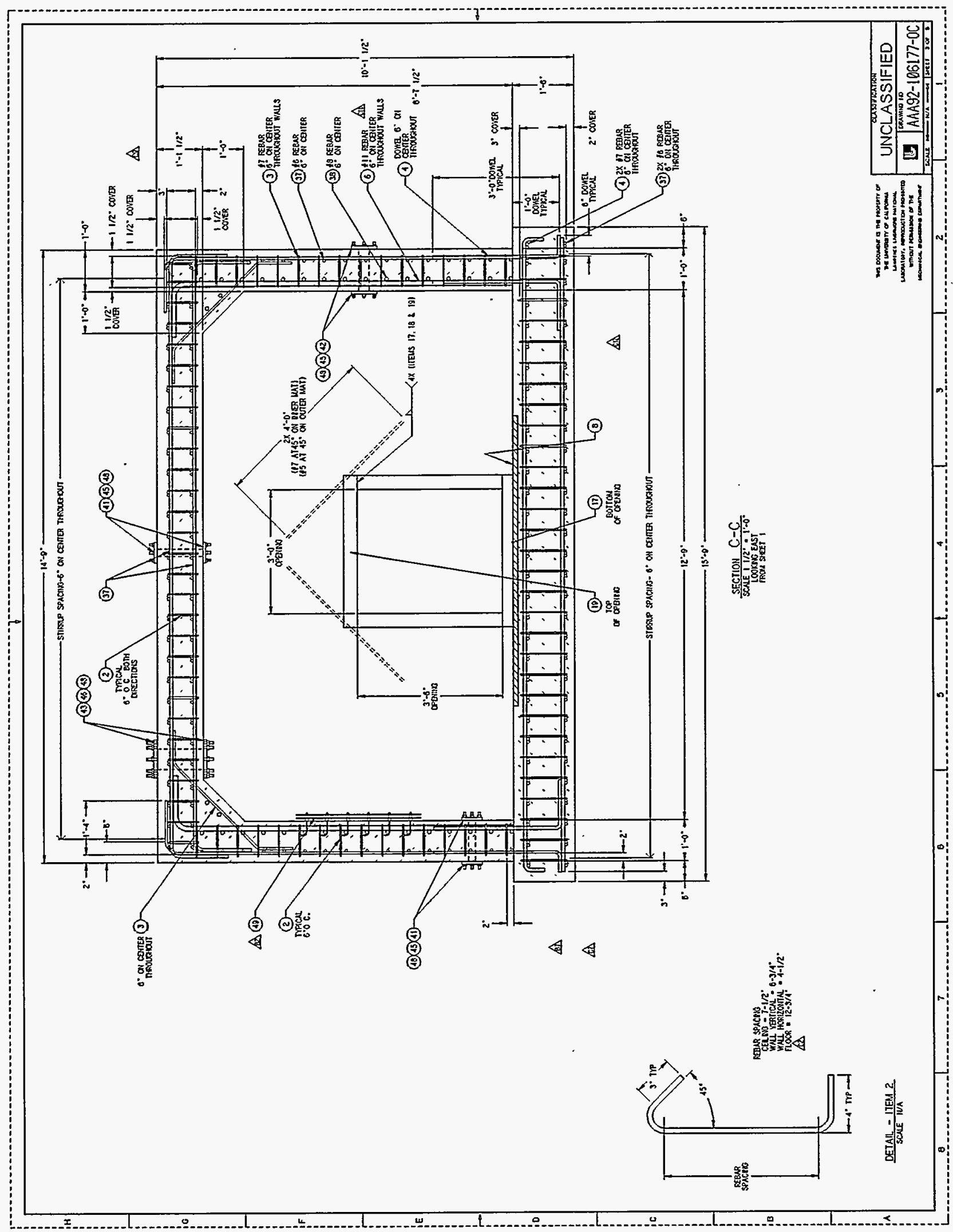




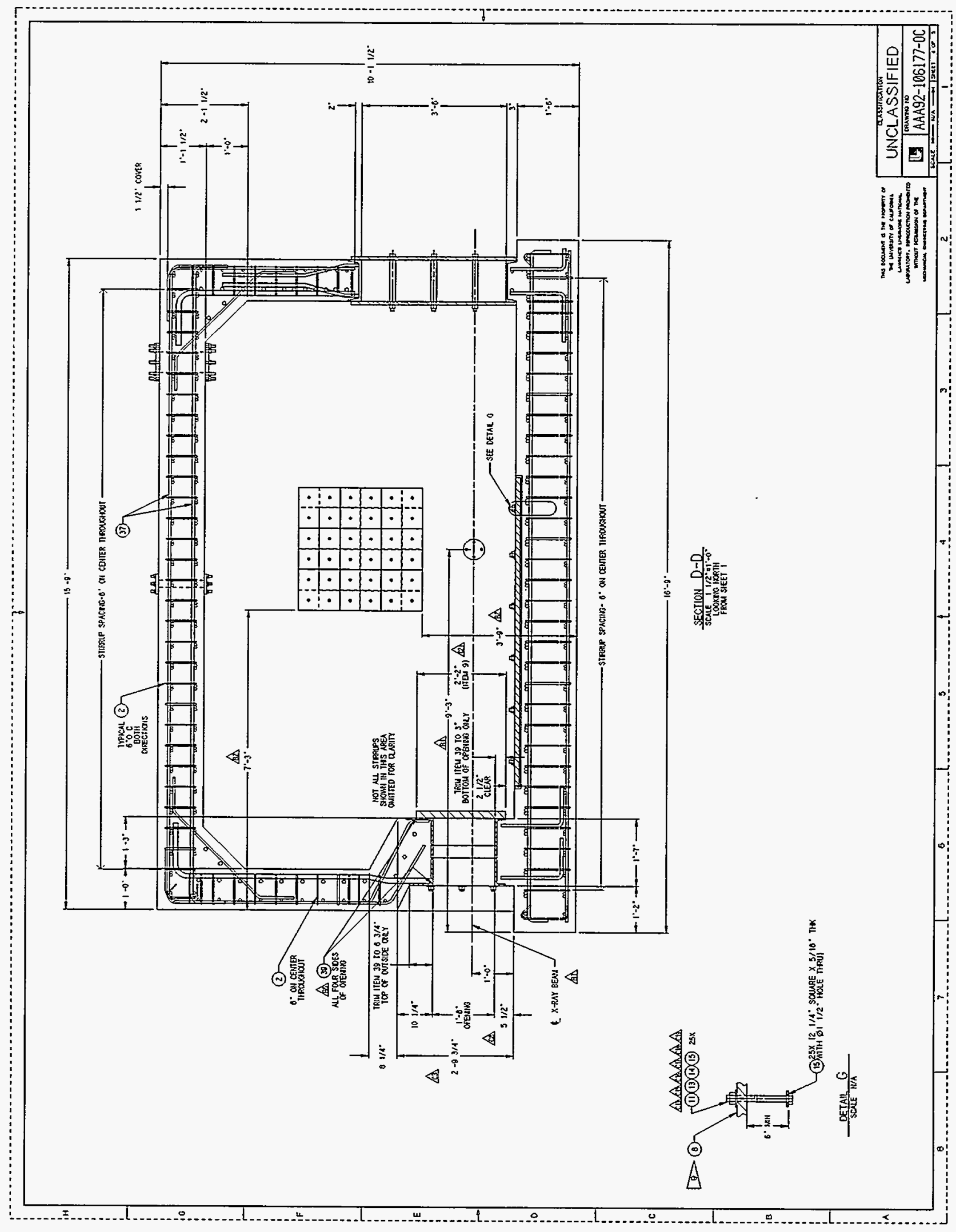




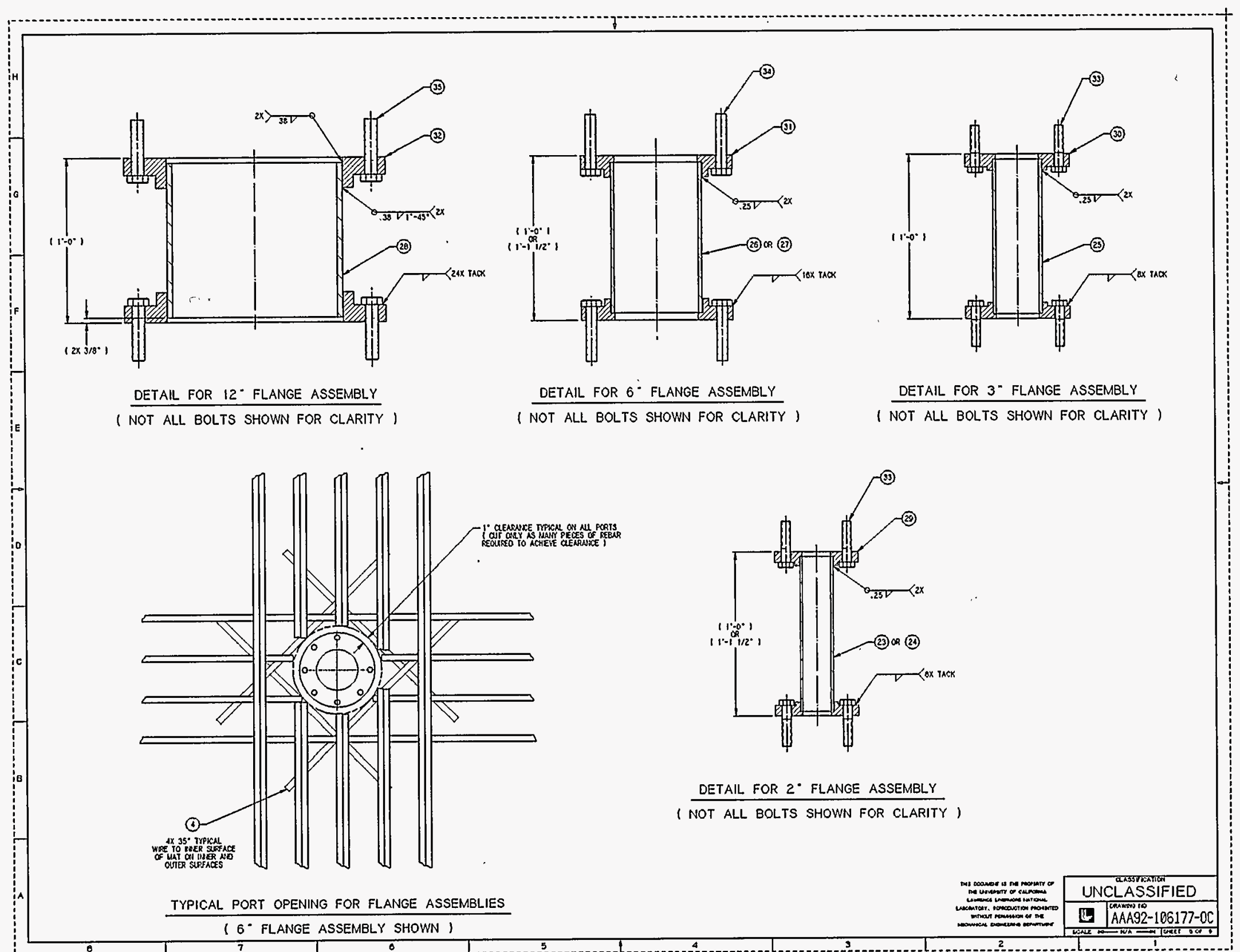




\section{Appendix C Instrumentation Drawings}

AAA93-103451 


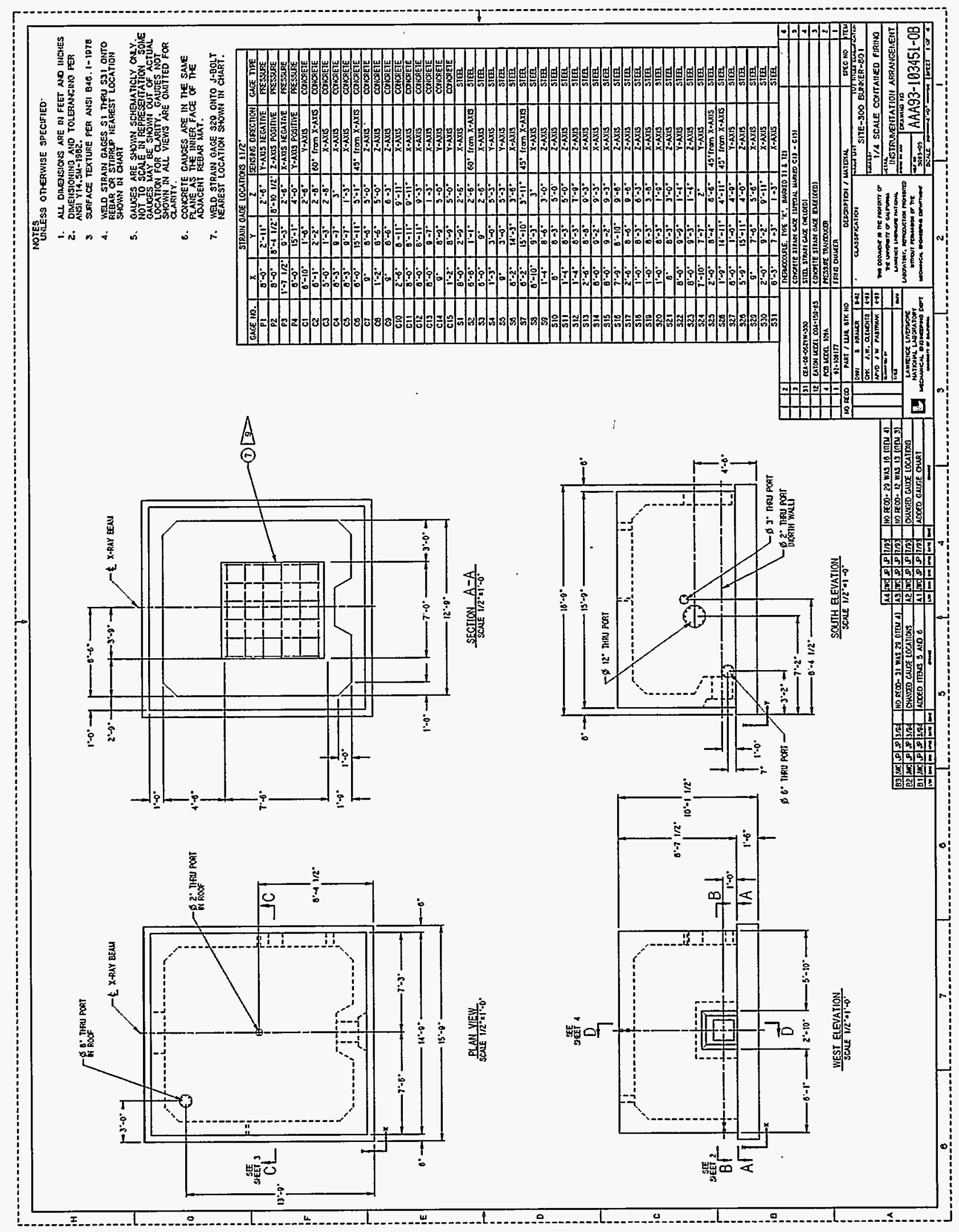




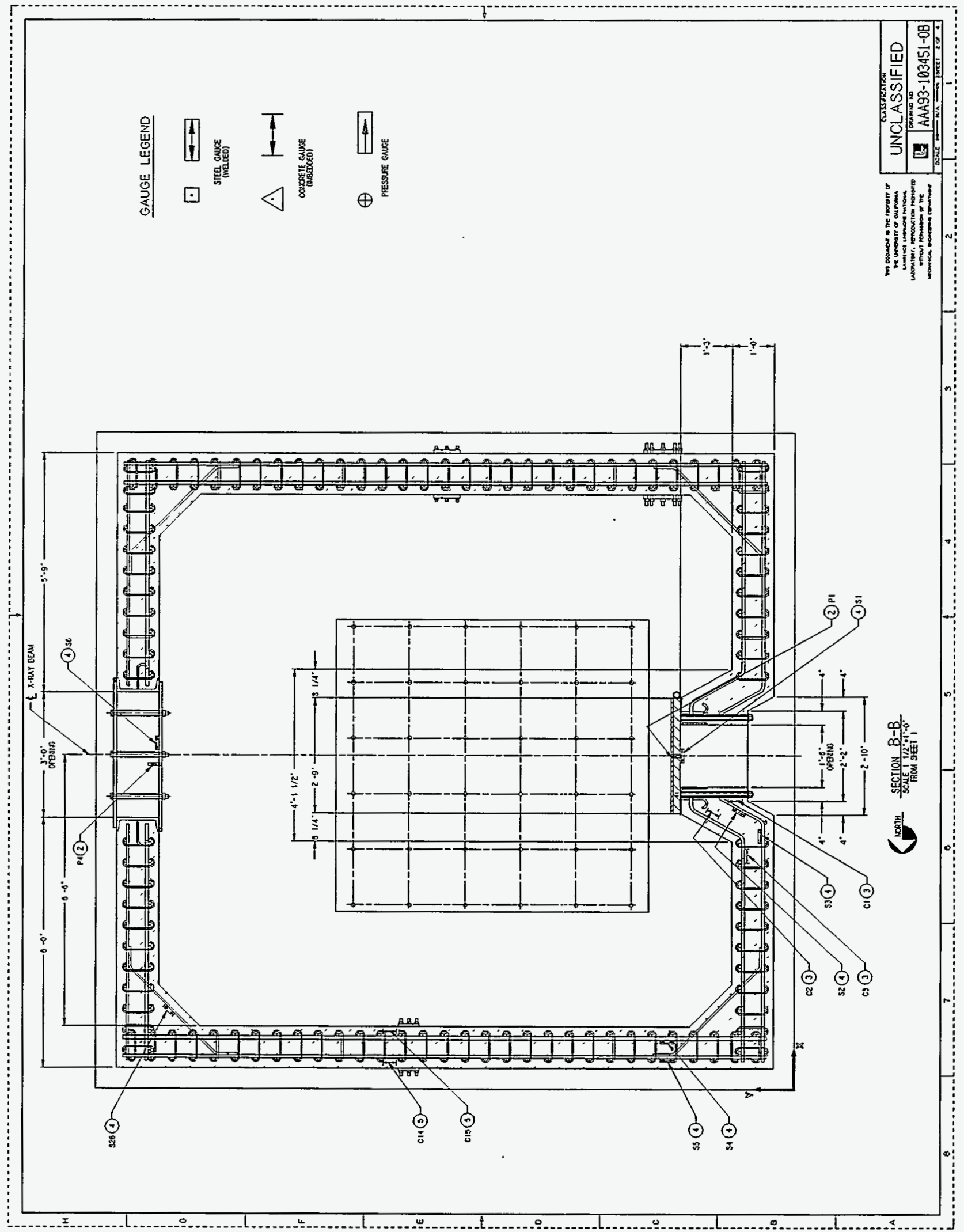




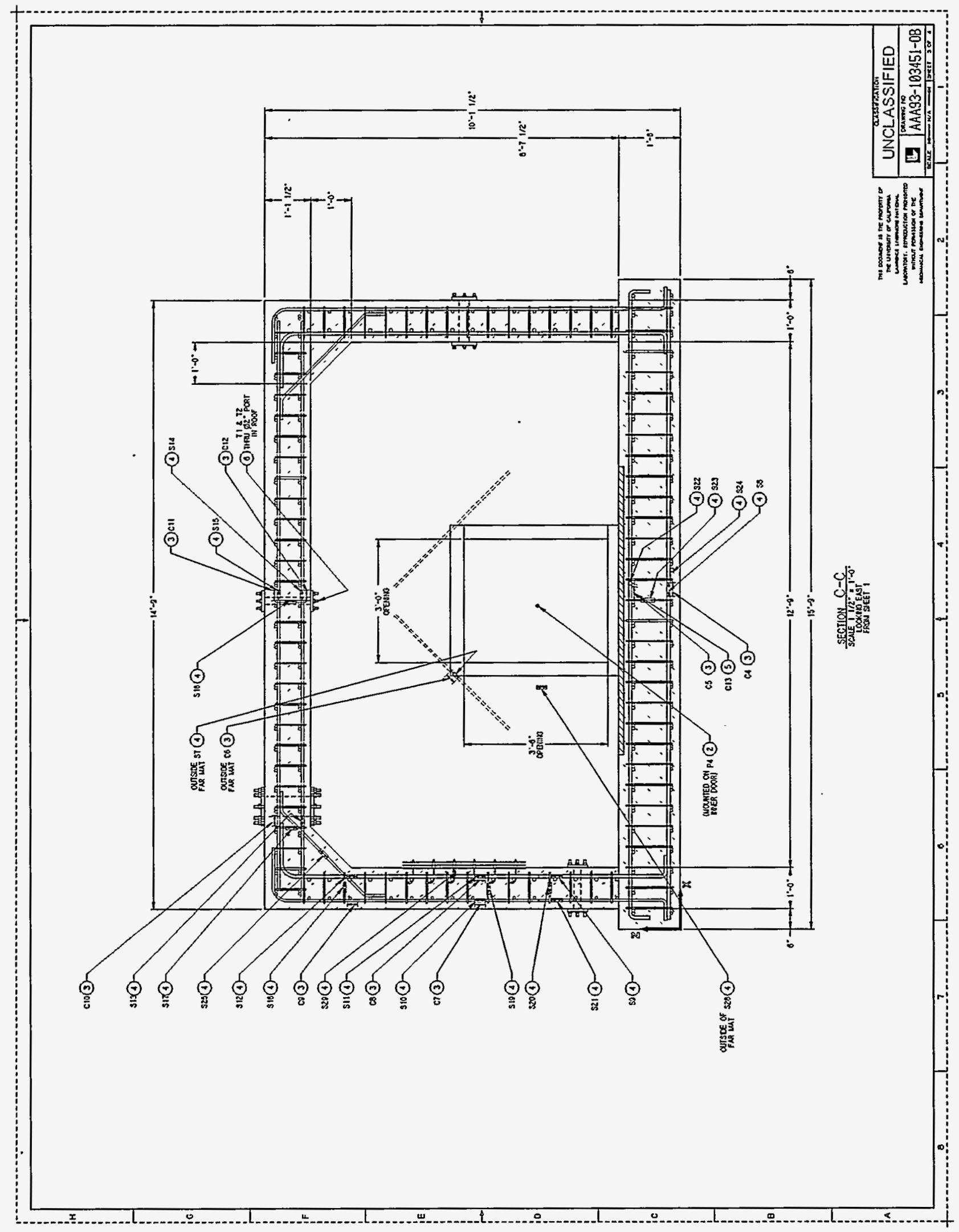




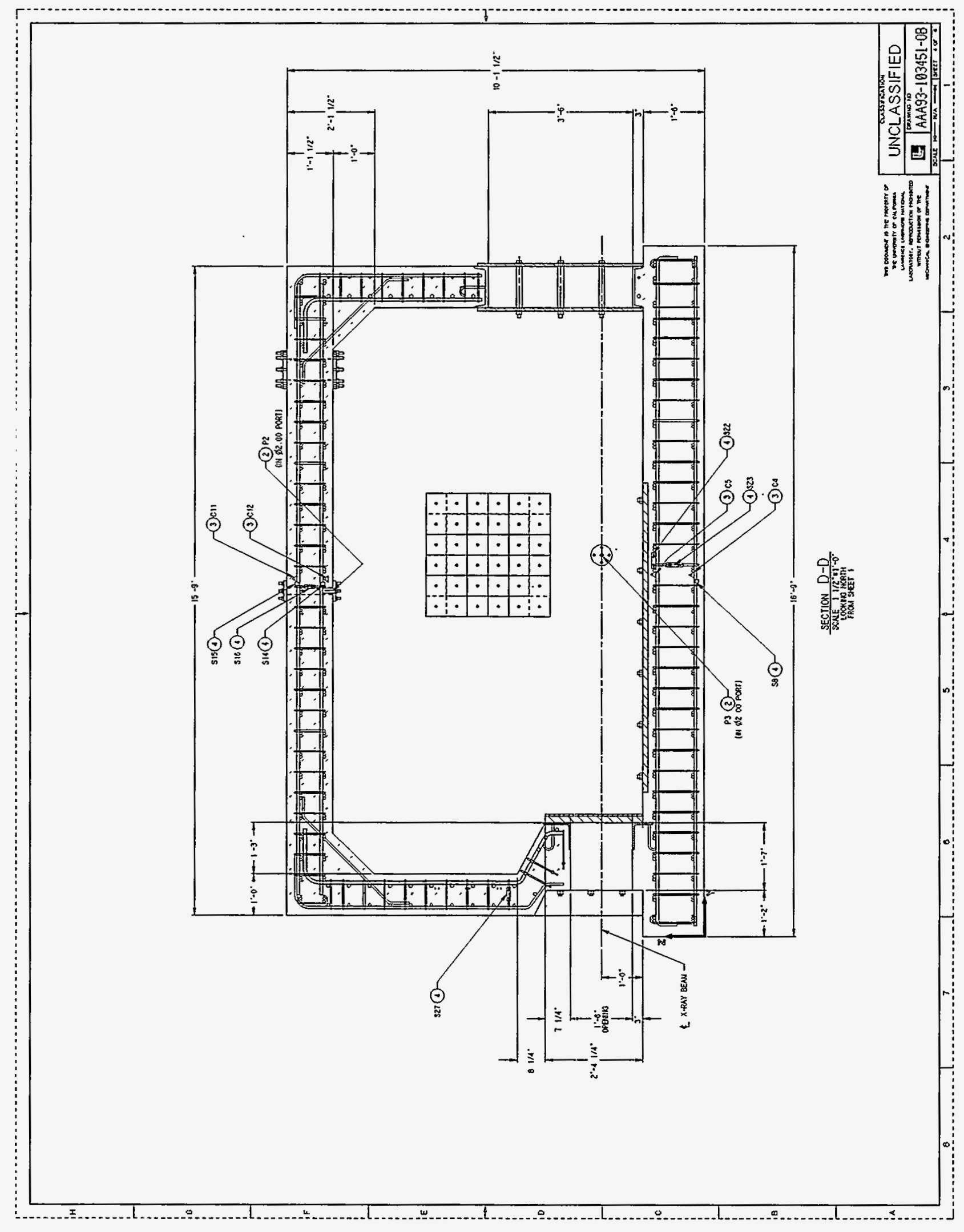

